Petrographic study of 47 sandstone samples from North Slope Alaska, 1972

Niem, A.R., Enlows, H.E., and Amoco Oil Co.

GMC DATA REPORT 448

This GMC data report from the Amoco Heritage collection has been made available through funding from the FY2018 USGS National Geological and Geophysical Data Preservation Program, Grant Number G18AP00054. This project report is presented in its original format and has not been reviewed for technical content or for conformity to the editorial standards of DGGS. It should not be used or cited as reviewed data.

2019

State of Alaska

Department of Natural Resources

Division of Geological \& Geophysical Surveys

GEOLOGIC MATERIALS CENTER
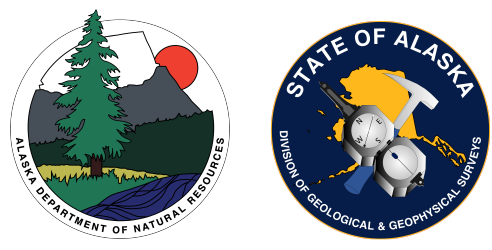
REPORT ON

PETROGRAPHIC STUDY OF 47 SANDSTONE

SAMPLES FROM THE NORTH SLOPE

$$
\text { CH } 72^{\text {OF ALASKA }} 25
$$




\section{Report on}

Petrographic Study of 47 Sandstone Samples

from the North Slope of Alaska

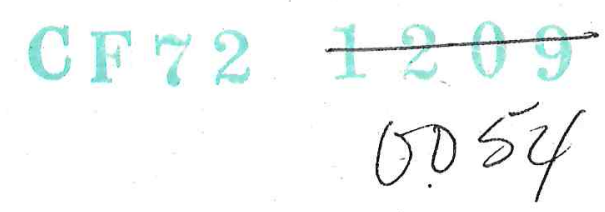

to

Union Oil Company

December, 1972

Consultants:

Alan $R$. Niem

Principal investigator Assistant Professor. Oregon State University Corvallis, Oregon

Harold E. Enlows Professor of Geology Oregon state University Corvallis, Oregon 
TABLE OF CONTENTS

I. Conclusions

II. Petrographic summary of comparison and

differences of the 9 suites of sandstones and igneous and metamorphic rocks

III. Petrographic Techniques

IV. Detailed petrographic sumary and petrographic sample descriptions

A. Group I; Iower Cretaceous sandstones of the Waring Mountaing

(sampleg RRR-209, 214, DWA-299)

41.

1. Petrographic report on RRR-209

2. 11

" On $\mathrm{RRR}-2] .4$

49

3.

i. on DWA-299

51.

B. Group II; lower Cretaceous rocks 70 to

170 miles east of Group I in the Waring

Mountains; (samples RRR-376A, 376B, 378 , $379,382 \mathrm{~A}, 382 \mathrm{~B}, 383,384,393,395,397$, $401,402,404)$

1. Petrographic report on $R R R-3764$

61

2. 1

" on $R R R-376 B$

64

3. "

18 on RRR-378

67

4. 1

1. - on RRR-379

70

5. 11

on $R R R-382 A$

72

6.

on RRR-382B

75

$7 . \quad 11$

on $\mathrm{RRR}-383$

78

8.

on RRR-384

81

9.

on RRR-393

84

10.

on PRR 395

87

11.

on RRR-397

90 
B. Group IT (continued

12. Petrographic report on RRR 401

13. "

is on $\mathrm{RRR}-4,02$

14. "

on $\mathrm{RRR}_{-4} \mathrm{OH}$

C. Group III; upper Cretaceous samples of the Waring Mountains; (samples RRR-266, 387, 389, 399, 403)

1. Petrographic report on RRR-266 107

2. " on RRR-387 109

3. " " on FRR-389 171

4. " " on RRR-399 113

5. " on $R R R-403 \quad 115$

$R R R-386 \quad 117,1 / 8$

D. Group IV; igneous or sedimentary? of the

Waring Mountains; associated with intrusive and extrust ve rocks;

(samples RRR-391 and 392)

1. Petrographic report on RRR-391

2. "I On RRR-392

E. Group V; Devonian sandatones of Schwatka

Mountains; (samples RRR-276, 359, 348)

1. Petrographic report on RRR-276 133

2. " 139

3. " " on RRR-348 136

F. Group VI; Jurasaic-Cretaceous sandstones of northwestern Brooles Range; (samples RRR-323, DWA-374, RRR-333, 336; one sample from Delong Mountaing RRR-310)

1. Petrographic report on RRR-323 
F. Group VI (continued)

3. Petrographic report on $R R R-333-$

5.

" on RRR-310

G. Group VII; upper Cretaceous sandstones near Sagwon northeastern Brooles Range; (samples RRR-412, 4I3, 4I4, 416, 418, $421,424,426,431$; Iower Cretaceous, RRR $-435,440$ )

1. Petrographic report on RRR-L12

2. 1

$1 \quad$ on $\operatorname{RRR}-413$

174

3. 11

" on RRR-LiL

177

4. 11

" on RRR-Lil6

180

5. 11

" on RRR- 418

182

6.11

* on RRR-421.

185

7.

" on RRR-424

187

$8 . \quad n$

n on RRR- 426

190

9. in

n on RRR-431

193

10.

" On PRR- 435

196

11 :

"

on RRR-440

198

H. Group VIII; pre-Devonian and Devonian metamorphics of Schwatka Mountains; (samples RRR-252 and 239)

1. Petrographic report on RRR-252

2.

" on RRR-239

I. Group IX; Triassic Shublik from Schwatka Mountains (sample DWA-329) 


\section{Mineralogy:}

1. The mineralogy of the five sandstone suites (Jower Cretaceous of the Waring basin; upper Cretaceous of the Waring basin; JuraesicCretaceous of northwestern Brooks Range and Delong Mountains; upper and. lower Cretaceous of the Sagwon region; and Devonian of the Schwatka Mountains) is distinctive and can be used to distinguish the various suites for correlating and age dating future samples collected in the field or from the subsurface. The major significant differences are:

a. The Iower Cretaceous suites of the Waring basin and JurassicCretaceous samples of the northwestern Brooks Range and Delong Mountains are characterized by abundant andesite and basalt volcanic rock fragments, mudstone fragments, a high plagioclase feldspar content (oligoclase and andesine), green hornblende, chert, colorless clinopyroxene, occasional granodiorite rock fragments, and chlorite, celadonite and yellowish chlorophaeite replaced clasts. There is a lack of metamorphic rock fragments, biotite, or muscovite, and the overall qusstz content is low.

b. The sandstones of the upper Cretaceous of the Waring lountains southwest of the Brooks Range and the lower and upper Cretaceous of the Sagwon area northeast of the Brooks Range are characterized by a high quartz content, a low feldspar content, abundant muscovite, biotite, mica schist, some quarizite and chert, and mudstone rock fragments. There is a lack of volcanic and granodiorite rock fragments, pyroxene, hornblende, or chlorite, celadonite, or chlorophaeite replaced clasts. 


\section{Source areas:}

a. The source areas (Brooks Range?) for the lower Cretaceous sandstones of the Waring basin and the Jurassic-Cretaceous sandstones of the northwegtern Brooks Range and Delong Mountaing consisted of predominantly basalt and andesite 1.ows, chert, and fine-grained gedimentaxy rocks (mudstone), minor lok-grade schist, quartzite, and actd igneous intrusives.

b. The source areas for the upper Cretaceous sandstones of the Waring basin and upper and lower Cretaceous sandstones of the Sagwon area consisted of predominantly low-grade metanomphics (quartz muscovite and biotite schist and some quartzite) and fine-grained sedimentary rocks mainly mudstones and minox amounts of volcanic flows. The mudstone clastg may be penecontemporaneous ripmups of the mud bottom.

c. Some active acidic rolcanisn occurred in late Cretaceous time which deposited ash in the Sagwon region (reworked vitric tuff sample $R R R-426)$.

d. A major change in type of source material for the sandstones in the Waring basin occurred from early cretaceous (volcanics) to late Cretaceous (10w-grade metamorphics). Perhaps lava flows in the source area were stripped away by erosion exposing the underlying older metamorphics.

o. The source area for the Devonjan sandstone samples (Neurokpuk, Precambrian-Silurian?) consisted of chert (Iimestone chert nodules, deepwater chert beds, or devitrified acidic volcanic glass), low-grade metamorphics, basalt and andesite lavas and tuffs, and fine-grained sedimentary rock (mairly mudstones). 
Relief and Climate:

a. The abundance of chemically unstable minerals and rock fragments (low mineralogical maturity) and general coarseness of the lower Cretaceous sandstones of the Waring basin and the Jurassic-Cretaceous rocks of the northwestern Brooks Range indicate that the detritus that forms these sandstones was rapidly eroded and transported from a rugged source terrain with steep relief (hills, mountains, high stream gradients, and active tectonism) in a temperate(?) climate.

b. The finex grain size, abundance of chemically stable quartz and chert, and low content of unstable minerals and rock fragments (high mineralogical maturity) in the upper and lover Cretaceous sandstones of the Sagwon region and the upper Cretaceous of the Waring basin suggest that the detritus that composes these sandstones was derived from low or gently roljing plains and hjlls with low stream gradients. The climate may have been warmer and more humid regulting in extensive chenical destruction of the unstable minerals and rock fragments to clays, thus enriching the sediments in quartz and chert.

\section{Depositional Enviromment and Transporting Mechanism:}

a. The coarge grain vize, poor sorting, angularity, and, in some samples, abundant original matrix of the lower Cretaceous sandstones of the Waring basin, the Jurassic-Cretaceous sandstones of the northwestern Brooks Range, and Devonian sandstone of the Schwatka Mountains suggest that these texturally immature sandstones were probably deposited in rapidly subsiding basing (geosynclines?) under conditions of rapid burial (high rates of sedimentation). Probable enviroments to produce the coarse-grained sandstones (arenites-lack matrix) are high energy deltaic or river channels or littoral or nexitic environment below wave base. The 
clay-rich finer grained sandstones (wackes) were deposited by weaker currents (low flow regime) in low energy environments with no sorting, winnowing of clays, or abragion of clasts such as in a deltaic overbank, swamp, lagoonal, estuarine, tidal flat or protected bay, or offshore deep marine below wave base (neritic, abyssal). Jurassic-Cretaceous sample DWA-374 arid Devonian sample RRR-376 which are composed of well-rounded sorted grains with no clay matrix may have been formed in an offshore bar or beach environment.

b. The lack of clay matrix, fair sorting, fine grain size ard abundance of quartz in the arenite samples of the uppex Cretaceous of the Sagwon region suggest deposition in an offshore littoral or deltaic enviroment (overbank, bay nouth bar, distributary channel). The occurrence of muscovite flakes, "soft" schist, mudstone clasts, and abundant angular quartz grains mitigate against deposition in high energy surf or eolian zones where there is constant abrasion over long periods of time. The higher abundance of quartz in the Cretaceous sandstones of the Sagwon region may also reflect the composition of the source area and/or the fine grain size of the samples. Rock fragments do notoccur in the fine sizes because they are broken down into clays before the small size is reached. Thus, the abundance of quartz may be only apparent.

c. The wackes or clay-rich sandstones of the upper Cretaceous of the Sagwon region were deposited in low energy enviromments (lagoonal, back bay, swamp, neritic) where fine clay could settle out and be rapidly buried (no reworking by weak currents or winnowing). Plant fragment-rich upper Cretaceous Sagwon sample RRR-4I6 was deposited and rapidly buried under reducing conditions (as in a swamp or lagoon) that protected organic matter from oxidation and decay. 
Some volcanic ash fall material (RRR-426) mixed with terrigenous detritus settled in the sea, lagoon, or swamp (low energy envixonments).

\section{Diagenetic Alteration:}

a. The Cretaceous rocks of the Sagwon region, the upper Cretaceous rocks of the Waring Mountains, and the Deronian samples of the Schwatka Mountains have undergone similar diagenetic histories. There has been . moderate to extensive compaction (contorted muscovite, mudstone and schist clasts) and development of micro-stylolites between adjacent quartz grains by pressure solution. Quartz overgrowths are rare. Some volcanic rock fragments and feldspar are altered to carbonate, sericite, chlorite, or greenish celadonite forming indistinct grain boundaries.

b. The lower Cretaceous of the Waring Mountains and the JurassicCretaceous of the northwestern Brooks Range and Delong Mountains have undergone extensive alteration due to the abundance of chemically unstable rock and mineral fragments that make up these sedimentary rocks. Compaction effects are not as apparent as in the sandstone suites in the group mentioned in. (a) above. The groundnass in the rolcanic rock fragments, vesicular volcanic(?) glass, and pyroxene have diagenetically altered to greenish celadonite, yellowish chlorophaejte, carbonate or bromish clay. Some samples have an authigenic matrix of the above products from obliteration of volcanic rock fragment boundaries. Iron minerals (magnetite and ilmenite) oxidized to hematite and leucoxene. Precipitation of pore filling carbonate cement occurs in JurassicCretaceous sandstones. Feldspar is comonly altered to sericite patches.

c. Extensive diagenetic alteration in Cretaceous samples RRR-391, and 392 from the Waring Mountains has occurred. An observable clastic 
texture suggests a sedimentary origin rather than an igneous origin.

\section{Classification:}

a. Upper Cretaceous sample (RRR-L26) from the Sagwon area is a rhyodacitic or dacitic shard-rich vitric tuff or tuffaceous wacke and is significantly different from the other quartz-rich upper cretaceous sandstones. The tuff, probably a widespread marker bed, could be used for widespread correlation purposes and recognizing stratigraphic position in the upper cretaceous.

b. The 43 sandatone samples range from volcanic, lithic, feldapathic and quartz wackes to arenites. No arkoses occur. Arenites are most abundant.

c. The lower and upper Cretaceous of the Sagwon region is composed predominantly of fine-grained quartz-rich feldspathic and schist arenites and wackes.

d. The upper Cretaceous of the Waring Mountains is predoninantly quartz and feldspathic arenites.

e. The lower Cretaceous sandstones of the Waring basin are predominantly volcanic and lithic (mixtures of volcanic, mudstone, and plutonic) arenites and wackes and are distinct from (c) and (d) above.

f. The Jurassic-Cretaceous sandstones consist of feldspathic, lithic, volcanic, and quartz arenites.

\section{Texture:}

a. The majority of sandstone samples are texturally immature to mature. They contain either abundant original and authigenic matrix or no matrix at all, are poorly to moderately sorted (less comonly wellsorted), and contain angular to subangular framework grains. 
b. Lower and upper Cretaceous rocks of the Sagwon area characteristically are very fine- to fine-grained. The grain gize in sandstones from other suites is much more variable and ranges from very fine sand to granule. Four samples are conglomeratic sandstones.

c. The finer grained the sandstone (f'ine to very fine sand), the more abundant the matrix and the more angular and elongate the framework grains are.

d. The upper and Iower cretaceous rocks of the Sagwon area are characteristically moderately to well-sorted; that is, better sorted than the Iower Cretaceous of the Waring Mountains.

Porosity and Cement:

The most probable potential petroleum reservoirs would occur in the lower and upper Cretaceous quartz-rich sandstones of the Sagron area and upper Cretaceous of the Waring Mountains where visible porosity is the highest $(717 \%$ to $10.5 \%)$. Porosity is 10 (2.8\% to $6.7 \%)$ in the "dirty" (diagenetically altered) volcanic sandstones of the lower cretaceous of the Waring Mountains, of the Devonian sandstones in the Schwatka Mountains and in the Jurassic-Cretaceous samples of the northwegtern Brooks Range, and Delong Mountains. Most of the porosity is intergranular variety and has been reduced in most sandstones by either inflling by carbonate cement of less commonly by henatite and leucosene cement or by the formation of a diagenetic matrix of chlorite and greenish celadonite or yellow chlorophaeite dexived from the alteration of rolcanic rock fragments. Quarta overgrowths are rare.

\section{Miscellaneous:}

1. RRR-386 is a porphyritic dacite or rhyodacite that intrudes lower Cretaceous rocks of the Waring lountains. The intrusion formed as a 
near surface plug or dome (flow?) under rapid cooling conditions. The former glassy groundmass has devitrified or altered to microcrystalline mixture of quartz, foldspar, and chlorite.

2. Triasgic Shublik sample DWA-329 is probably a hydrothermally altered hematitic mudstone. The mudstone was permeated several times by hydrothemal solutions that produced opaque globules of metallic hematite replacing siderite rhombs and veinlets of chalcedony, baxite, and zeolites replacing the clay matrix.

3. RRR-239 (pre-Devonian) and MRR-252 (Devonian) Prom the Schwatka Mountains are micaceous quartzite. These quartaite samples may be the type of metamorphic roeks that acted as a source of the low-grade quartz mica schist and quartzite detritus deposited in the Waring basin during late Cretaceous time and in the Sagwon region northeast of the Brooks Range in early and late Cretaceous. The pre-Devonian and Devonian metamorphic micaceous quartrites were probably originally quartz sandstone. Derowian quartzite sample RRR-252 is highly sheared. 
North Slope Samples

Petrographic Study Summary

The 47 samples have been grouped into nine different categories on the basis of geologic age, field location, and description. The nine groups are:

Color Code on

Sketch Map (Fig. 1)

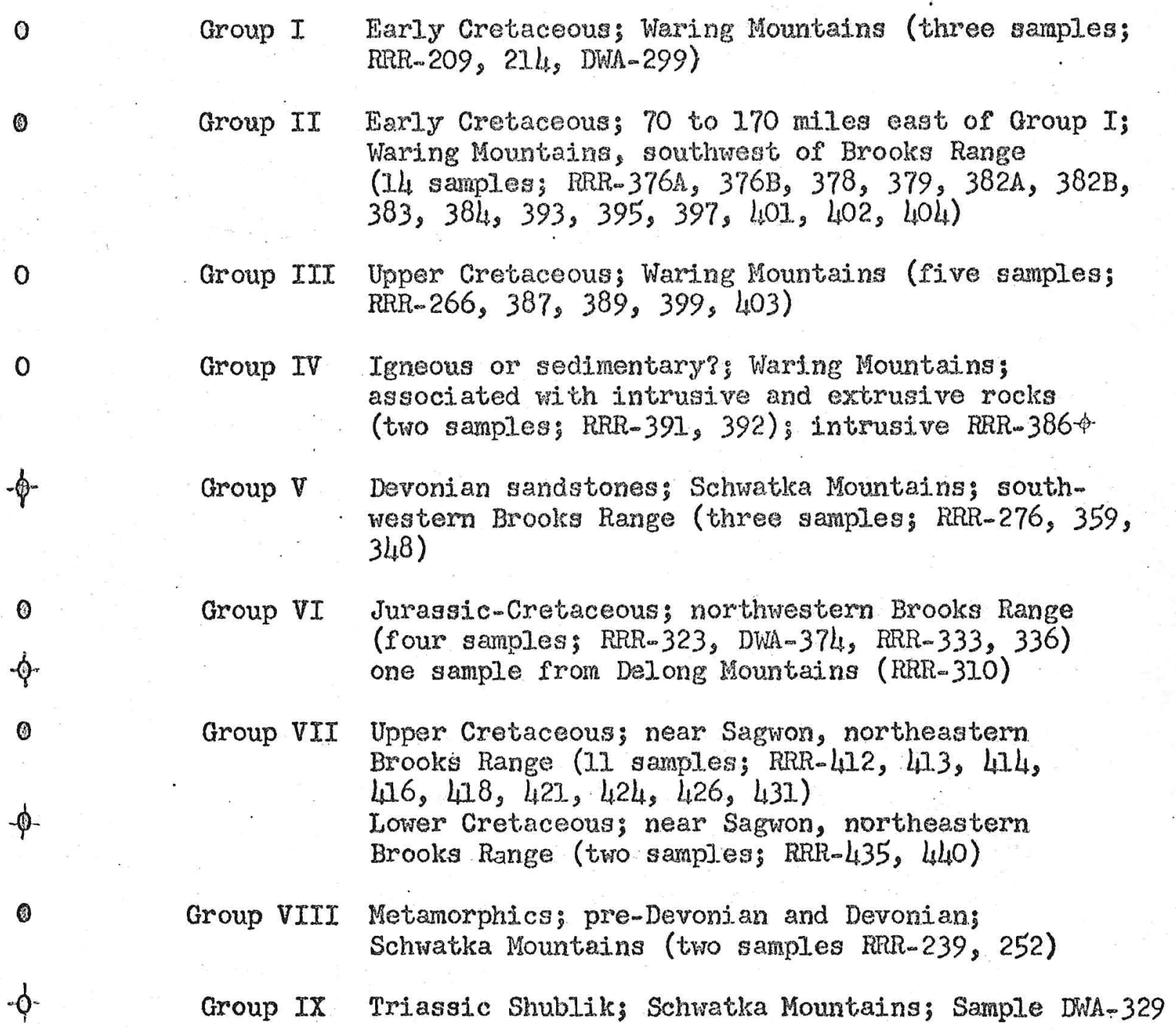

This general summary is to point out major or distinctive characteristic similarities and differences between major groups of North SIope samples. Detailed petrographic summaries of each group are included on separate sheets as well as detailed descriptions on each sample. 


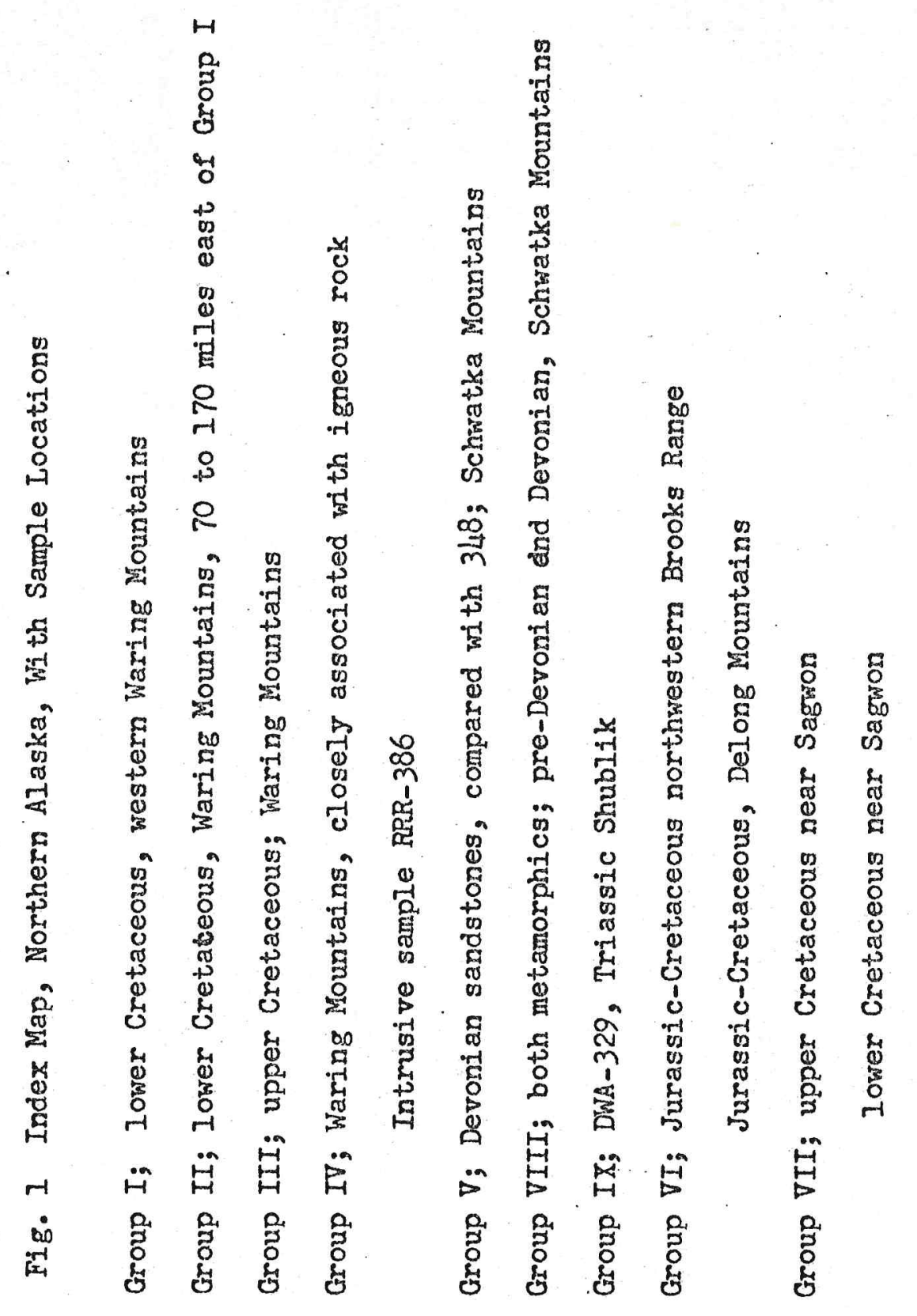

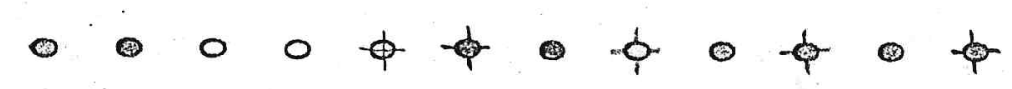




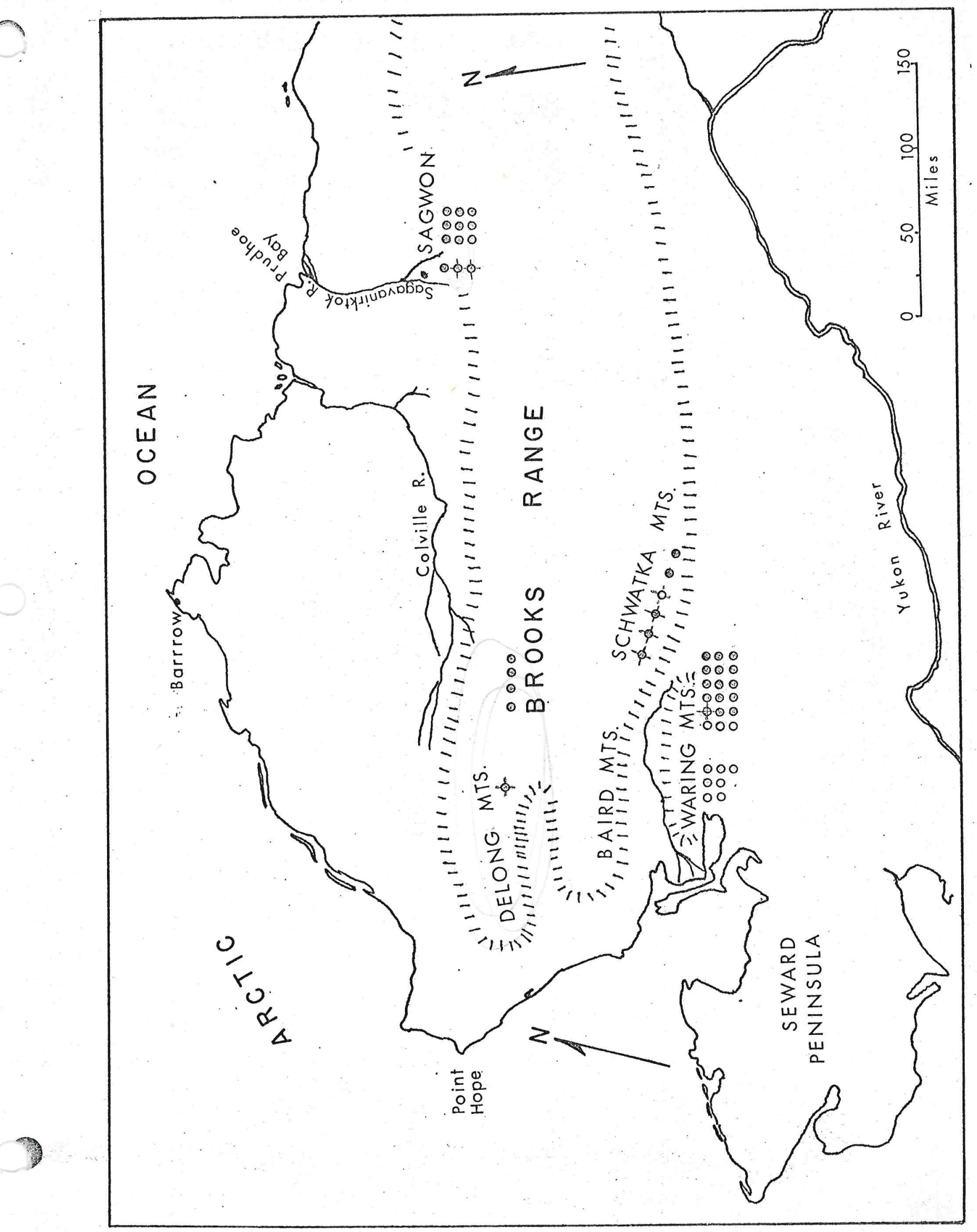


Classification: Both RRR-239 (pre-Devonian) and RRR-252 (Devonian) from the Schwatka Mountains are micaceous quartzites (or gneisses?). RRR-252 is a highly sheared micaceous quartzite (or gneiss?). Sample RRR-386 is a porphyritic dacite or rhyodacite intrusive that intruded lower Cretaceous rocks in an east-west trending basin south of the Brooks Range (Waring Mountains).

There are 43 sandstone samples. There is a considerable range from vol.canic to quartz wacke and arenite. Arkoses or arkosic arenites are absent (see Gilbert classification diagram, figures 2 and 3, this report). There are 17 wackes ( $>10 \%$ matrix); three of which are feldspathic wackes, 2 arkosic wackes, 4 volcanic wackes, 2 lithic wackes, 4 subfeldspathic lithic wackes, and only one quartz wacke. The arenites are the most abundant samples in these sandstone suites. of 26 arenites, there are 7 volcanic arenites, 5 lithic arenites, 4 subfeldspathic arenites, and 6 quartz arenites. There are no arkosic arenites or arkoses.

By individual suites: Group VII, the lower and upper Cretaceous of the Sagwon area is split almost equally in number of arenites and wackes. Most of the samples are predominantly feldspathic and lithic (schist) arenites or wackes. There is only one quartz wacke, and one upper Cretaceous sample $(R R R-426)$ is a rhyodacitic or dacitic vitric tuff or tuffaceous wacke.

Group III (the upper Cretaceous of the Waring Mountains) is predominantly quartz and feldspathic arenite with only one subfeldspathic lithic wacke. The three Devonian sandstones are quartz and lithic (mudstone) arenites and one subfeldspathic lithic (pyroxene) wacke.

The Iower Cretaceous sandstones of the Waring basin, Group I, II, and IV(?), are predominantly lithic (volcanic, mudstone, plutonic) and 
in

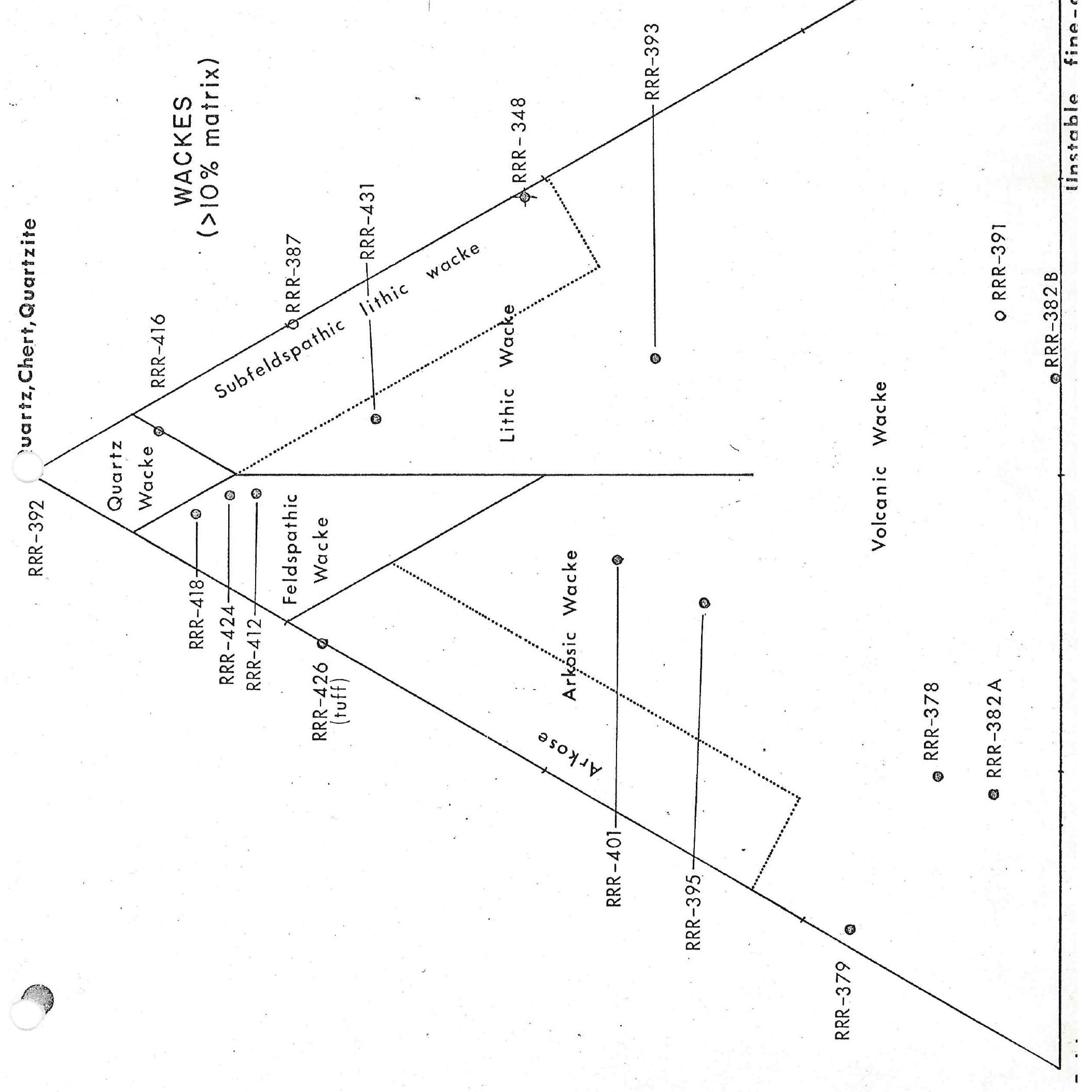

Gilbert, 1954 


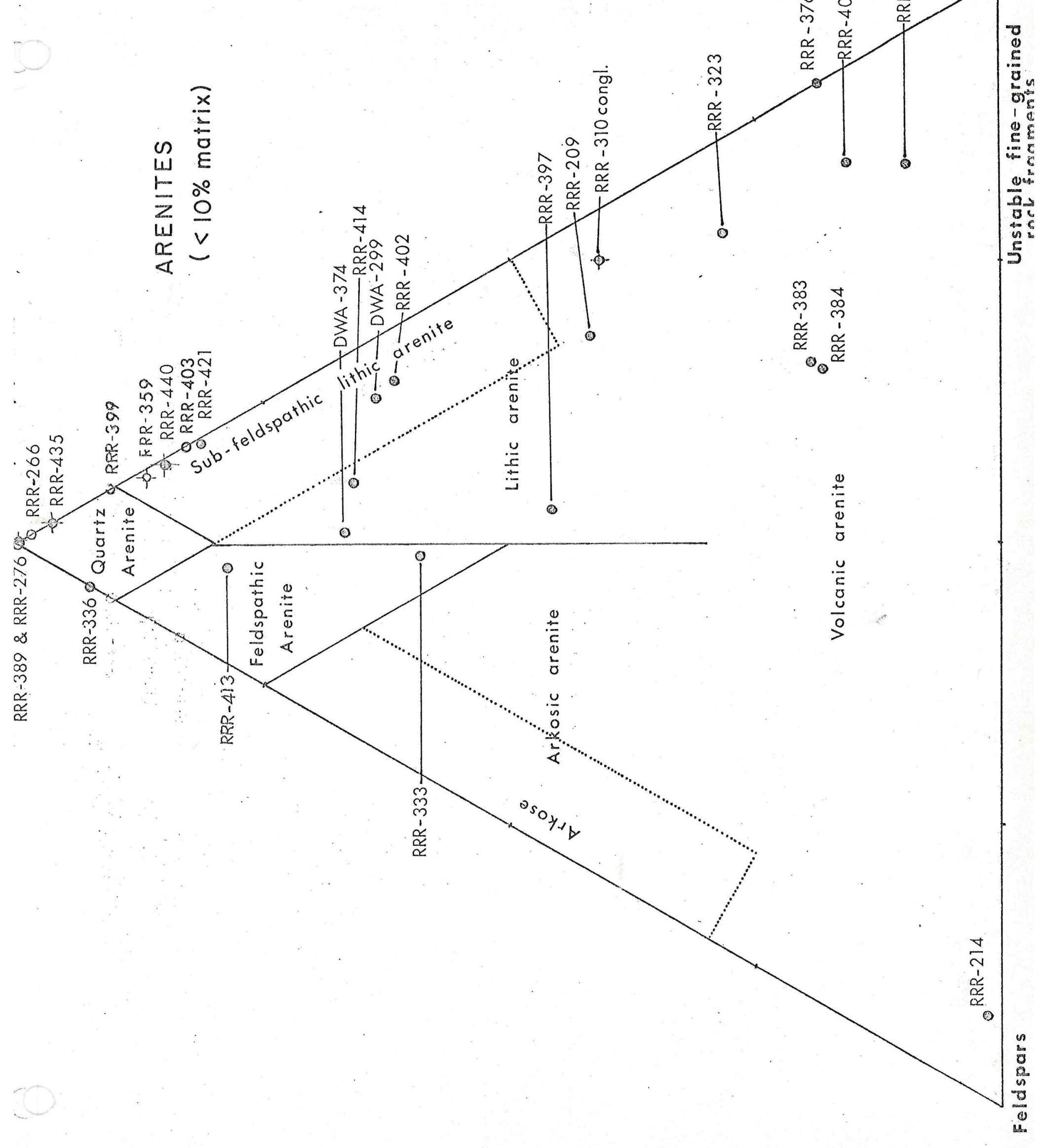

Gilbert, 1954 
volcanic arenites and wackes with a few arkosic wackes and arenites or subfeldspathic lithic wackes. Thus, as a group, the lower Cretaceous rocks of the Waring basin are distinct from the Devonian and upper Cretaceous of the Waring Mountains and the lower and upper Cretaceous of the Sagwon region which are mainly quartz and arkosic or feldspathic wackes and arenites. The Iithic sandstones of the Iower Cretaceous of the Waring basin are composed of a variety of volcanic, plutonic, and sedinentary rock fragments and pyroxene and hormblende. Only in Group IV is one silty quartz wacke present. There are no true arkosic or feldspathic sandstones.

Group VI, the five Jurassic-cretaceous samples, consists of feldspathic lithic, volcanic, and quartz arenites. Group IX, Triassic Shublik sample DWA-329, is probably a hydrothermally altered hematitic mudstone.

Texture: The great majority of these sandstone samples are texturally immature to mature (Folk's classification). That is, they contain either abundant clay matrix (some of which is authigenic in origin) or little or no matrix, are poorly to moderately sorted (more rarely well-sorted), and contain angular to subangular framework clasts.

Within this limited sampling, the 12 lower and upper Cretaceous samples of the Sagwon area (Group VII samples) are characteristically very fine- to fine-grained sandstones whereas samples in the other groups (except the Devonian) range from very fine sand to granule in size. The three Devonian samples from the Schwatka Mountains are medium- to coarsegrained. In general, the finer grained the sandstone (e.g. fine sand size and finer), the more abundant the matrix content; hence the wacke classification and also the more angular and elongate the framework clasts 
are. Besides being finer grained than the upper and Iower Cretaceous rocks of the Waring basin, the upper and lower Cretaceous rocks of the Sagwon area are better sorted than the lower Cretaceous rocks of the Waring Mountains.

Overall, visible porosity is highest in the upper and lower Cretaceous rocks of the Sagwon region (average 7.7\% for 12 samples) and in the upper Cretaceous rocks of the Waring Mountains (10.5\% for 5 samples) compared to the "dirty" (diagenetically altered) voleanic sandstones of the lower Cretaceous rocks of the Waring Mountains (2.8\% for 14 samples in Group II; $3.0 \%$ for 3 samples in Group I; less than $3.0 \%$ in Group V Devonian sandstones) and in the four Jurassic-Cretaceous samples (2.0\% to 6.7\%) of the northwestern Brooks Range. Thus, the most probable potential petroleum reservoirs would be in the upper and lower Cretaceous Sagwon rocks and the upper Cretaceous of the Waring Mountains which have the greatest porosities.

The Jurassic-Cretaceous samples of the northwestern Brooks Range and Delong Mountaing are characterized by an abundance of pore filling carbonate cement and less abundant hematite and leucoxene cement. Quartz overgrowths are rare to non-existent in most of these North Slope samples. Almost all the groups have one or more samples showing a preferred orientation of the framework minerals or some laminations. The majority of the samples contain framework minerals in grain support.

Mineralogy: Petrographic study shows the mineralogy of the various suites is distinctive and can be used to distinguish and recognize different suites and by that recognition date future samples collected in the field or drill hole. 
The lower Cretaceous suites (Groups I, II and IV) of the Waring basin are mineralogically similar in terms of types of major minerals and their abundance. They are characterized by low to moderate abundance of strained and mosaic (polycxystalline) quartz (range: trace to 37.7\%; average 13.0\%); abundant rock fragments (average $20.8 \%$ ) such as volcanic rock fragments (hornblende andesite with porphyritic pilotaxitic and intersertal textures), abundant dark brown and laminated carbonaceous mudstone clasts (average $4.2 \%$ ), occurrence of green hormblende and coloriess clinopyroxene, abundant plagioclase feldspar (oligoclase and andesine $\mathrm{An}_{12^{A}} \mathrm{~B}_{88}$ to $\mathrm{An}_{32^{\mathrm{Ab}}} \mathrm{B}_{68}$ ) and untrinned feldspar, occasional acidic intrusive clasts (granodiorite), and abundant diagenetically altered greenish fibrous chlorite, celadonite, or fibrous yellowish chlorophaeite replaced clasts; some of which contain spherical amygdules infilled with radiating chlorite or celadonite. Heavy minerals include predominantly opaque iron oxides magnetite/ilmenite, hematite, leucoxene, and traces of zircon. These samples rarely contain microcline, micrographic quartz, quartz with toumaline inclusions, muscovite, biotite (except Group I), metamorphic rock fragments (schist or quartzite), or siltstone clasts.

Group I (western Waring Mountains) differs slightig in mineralogy from Group II (70 to 170 miles east of Group I in the eastern Waring Mountains) in that the Group I samples contain abundant carbonate cement and carbonate replaced clasts and littlo or no celadonite clay matrix and little hematite or leucoxene cement which is prevalent in Group II. Group IV (igneous or sedimentary?; samples RRR-391, -392) from the Waring basin although highly altered and/or fine-grained contains many of the same mineral and rock fragments as the other lower Cretaceous samples and is therefore thought to be also of lower Cretaceous age (see general comments section for specifics). 
The mineralogy of the Jurassic-Cretaceous suite of the northwestern Brooks Range and Delong Mountains is similar to that of the lower Cretaceous rocks of the Waring basin in southwestern Brooks Range in that both suites contain volcanic rock fragments (hornblende andeajtes), plagioclase feldspar (oligoclase and andesine), untwinned feldspar, abundant mudstone rock fragments, chert, plutonic rock fragments (granodiorite), and very low percentage of quartzite or schist. The Jurassic-Cretaceous suite tends to be a little higher in quartz content, have less authigenic matrix, and more rounded grains and better sorted than the early Cretaceous suite of the Waring basin suggesting slightly more agitated enviroments for the Jurassic-Cretaceous and more winnowing of clays. But both suites appear to have the same type of provenance in the Brooks Range which apparently shed detritus north and south into the Waring basin and the area of the present Delong Mountains. Since these Jurassic-Cretaceous rocks are similar in texture and mineralogy to that of the lower Cretaceous, it is suggested that the bulk of the samples may be lower Cretaceous in age. They do not resemble the muscovite and schistrich quartz sandstones of the upper cretaceous of the Waring basin. They are distinct from the lower Cretaceous of the Waring Mountains (Group II) in that they contain extensive carbonate cement.

The upper Cretaceous of the Waring Mountains southwest of the Brooks Range and the Iower and upper Cretaceous of the Sagwon area northeast of the Brooks Range are similar mineralogically and are distinctly different in mineral content from the lower Cretaceous of the Waring Mountains and the Jurassic-Cretaceous of northwestern Brooks Range and Delong Mountains.

1. Quartz content is high (average 4I.1\%); it is the mogt abundant mineral in the two suites (unlike the lower Cretaceous; average 12.2\%). The quartz content is also higher than the quartz content in the Jurassic- 
Cretaceous suite (average 30.1\%). The lower Cretaceous of the Sagwon region has a lower quartz content (18.0\%): The fine grain size may account for the quartz richness in the upper Cretaceous of the Sagwon region compared to generally coaxser grain size in other suites (most rock fragments and unstable mineralg breakdown and are destroyed at this fine grain size).

2. Feldspar content is low (average 2.6\%) unlike the higher content in the lower Cretaceous of the Waring basin and more like that of the Jurassic-Cretaceous rocks northwest of the Brooks Range.

3. Muscovite and biotite are relatively abundant (average $3.3 \%$ ) in these upper and lower Cretaceous samples compared with the trace occurrence in the lower Cretaceous rocks of the Waring basin and the Jurassic-Cretaceous rocks northwest of the Brooks Range. There is also a lack of the authigenic chlorite and celadonite replaced clasts found in the lower Cretaceous of the Waring Mountains and Jurassic-Cretaceous rock suites northwest of the Brooks Range and Delong Mountains.

4. Significantly, there is a lack of green hornblende and/or colorless pyroxene in these upper cretaceous rocks although the Jurassic-Cretaceous and the Iower Cretaceous of the Waring Mountains contain them in significant amounts.

5. The abundance of rock fragments is relatively low (average 12.6\%) compared to the $23 \%$ rock fragments in the lower Cretaceous samples of the Waring basin and the Jurassic-Cretaceous of the northwestern Brooks Range. The low percentage may reflect the finer grain size of the samples. Rock fragments do not normally occur in such fine sizes.

6. Quartz muscovite schist rock fragments (average 3.4\%) are one of the most abundant types of rock fragments in the lower and upper 
Cretaceous of the Sagwon region (trace to 12.2\%) and upper Cretaceous of the Waring Mountains (trace to $13.2 \%$; average $4.8 \%$ ). This contrasts with the Iower Cretaceous rocks of the Waring Mountains and the JurassicCretaceous northwest of the Broolss Range which contain no schist fragments to only traces of schist even though they contain an abundance of other rock fragments (average 23.3\%). Micaceous quartitite rock fragments only occur in trace amounts in the lower and upper Cretaceous suites of the Sagwon region but compose up to $16.3 \%$ of the upper Cretaceous samples of the Waring basin (average 5.1\%).

7. Chert content is generally low compared to overall mineralogical abundance (trace to $11.5 \%$ ) in Group VII of the Sagwon region and a trace to $8.3 \%$ (average 4.3\%) in Group III of the Waring Mountains but is one of the more abundant types of rock fragments.

8. The percentage of rolcanic rock fragments is very low (mainly non-existent to $3.2 \%$ ) compared with the lower cretaceous of the Waring Mountains ( $1.9 \%$ to $61.5 \%$; average $25.4 \%$ ) and the Jurassic-Cretaceous northwest of the Brooks Range (trace to $12.7 \%$ ). Most rock fragments are of intermediate lava flow composition with pilotaxitic and intersertal texture of feldspar microlites. The celadonite/chlorite amygduloidal replaced clasts and altered glass(?) of the lower cretaceous of the Waring Mountains and Jurassic-Cretaceous of the northwestern Brooks Range are missing from this suite.

Only sample RRR-426 (upper Cretaceous of Sagwon region) which is a dacitic or rhyodacitic tuff containsabundant sickle-shaped glass shards (29.9\%). Many of them have altered to the zeolite analcime(?) and heulandite and chert.

9. Sedimentary rock fragments in the upper Cretaceous rocks are similar to those found in the Jurassic-Cretaceous and lower Cretaceous 
of the Waring Mountains. Mudstone and argillite (or slate) are one of the most abundant types of rock fragments in most upper Cretaceous samples although this percentage abundance is low in comparison to total mineralogy (trace to $7.0 \%$ ). Siltstone rock fragments are rare in the lower and upper Cretaceous rocks of the Sagwon region. In contrast, however, siltstone rock fragments are relatively abundant $(0.5 \%$ to $7.4 \%$; average $3.9 \%$ ) and mudstone is rare in the upper Cretaceous of the Waring Mountains. Carbonaceous cellular plant matter is unusually abundant in sample RRR-416, an upper Cretaceous sample of the Sagwon area.

10. Heavy minerals range from a trace to $6.4 \%$ (in Group VII) and from a trace to less than $1.2 \%$ (in Group III). They are predominantly the opaque iron oxides (hematite and leucoxene followed by magnetite and/or ilmenite) with trace amounts, in some samples, of apatite, zircon, green tourmaline, epidote, and rutile needles.

11. Other minerals include glauconite(?) in sample RRR-435 (upper Cretaceous Sagwon area) and carbonate replaced minerals in some samples.

Devonian samples (Group V) - the mineralogy of the Devonian sandstone samples (RRR-346, 359, and 276) varies more from sample to sample than in other suites. The mineralogy is also distinct from the mineralogy of other suites.

In the Devonian samples from the Schwatka Mountains quartz content is high (24.3\% to $31.3 \%$ ) in RRR-359 and 276 but low (5.6\%) in RRR-348. Normal or nonundulatory quartz is twice as abundant as mosaic quartz in RRR-359 and 276. On the other hand, mosaic or polycrystalline quartz is more abundant (3.4\%) than the normal quartz (2.2\%) in RRR-348. Feldapar content is very low (trace to $0.1 \%$ ) and muscovite and sericite replaced clasts content is low (trace to $1.6 \%$ ) except in RRR-348 in which sericite 
replaced clasts are common (21.9\%). Heavy minerals (trace to $7 \%$ ) are mainly the oprque iron oxide, leucoxene, with traces of hematite, green tourmaline, and/or zircon in some samples. Pyroxene (colorless pyroxene - pigeonite?) is very abundant (15.4\%) in RRR-348; the other two samples contain none.

Chert (with micro mosaic quartz veins) is extremely abundant (55.5\%) as in RRR-276, high $(6.8 \%)$ in RRR-359, and Iow (3.2\%) in RRR-348. Mudstone $(6.6 \%$ and $5.5 \%)$ occurs only in two samples, a trace of schist and siltstone only in RRR-359, traces of altered roleanic lava rock fragments, and authigenic celadonite/chlorite replaced clasts occur only in RRR-348. Both RRR-359 and 348 contain large carbonate replaced clasts (up to $20 \%$ in RRR-348) as well as containing carbonate and limonite cement. RRR-276 contains hematite cement. A summary comparison of the mineralogy of RRR-359 and 348 is made in the general comments section (page 22).

The metamorphic rocks, RRR-252 (Devonian sheared micaceous quartzite) and RRR-276 (pre-Devonian micaceous quartzite from the Schwatka Mountains), consist of predominantly interlocking crystals of strained mosaic or polycrystalline quartz $(81 \%)$ with scattered chlorite needles. A metamorphic foliation is defined by aligment of trains of large muscovite and, more rarely, chlorite flakes separated by crystalline quartz. Traces of hematite, colorless zircon, green toumaline, and epidote are associated with the abundant polycrystalline or mosaic quartz. In addition, the sheared sample RRR-252 contains large strained coarse sand sized crystals ("porphyroclasts") of quartz, granoblastic micro quartz veins, and several sets of micro "ptygmatic" folds defined by microgranular quartz veins and magnetite which are cut across by the megascopic fabric of trains of muscovite flakes. Several zones of varying sizes of granulated polycrystalline quartz define shear surfaces. 
Hydrothermally altered mudstone, the Triassic Shublik sample DWA-329 from the Schwatka Mountains, consists of predominantly abundant coarse sand size dark opaque metallic hematite globules and rhombs $(46.8 \%)$ in a greenish clay (celadonite, chlorite, or montmorillonite) matrix. A few carbonate (siderite, Jess than 1.6\%) rhombs (partly replaced by hematite) also occur. The matrix also contains a few gilt gize mica flakes, green tourmaline, and spherical grains of mosaic quartz (recrystallized radiolaria?) as well as opaque contorted fibers of lencoxene and limonite surrouxding the edges of the metallic hematite globules. Hicro-veinlets cutting across hematite globules and matrix consist of mosajè quart\%, bladed zeolites, and large crystals of barite.

Porphyritic dacj.te or rhyodacite intrugive sample RRR-386 from the southern Brooks Range which intrudes early Cretaceous rocks in the Waring Mountains consists of phenocrysts of quartz (13.0\%) and plagioclase feldspar (albite, acid andesine, oligoclase) in a groundmass (61.3\%) of interlocking microcrystalline mixture of strained quartz, feldspar microlites, and chlorite aggregates. Heavy minerals (magnetite or ilmenite) occur as small cubes and octahedrons dispersed throughout the microcrystalline quartz groundmass; Jeucoxene occurs as irregular opaque aggregates in the groundmass. Hematite which occurs as black opaque stringers is associated with chlorite (7.4\%) that infills micro-fractures and also replaces the boundaries of quartz and feldspar phenocrysts.

Provenance: .. The mineralogy of the lower Cretaceous samples of the Waring Mountains and the Jurassic-Cretaceous, northwest of the Brooks Range and the Delong Mountains, suggests a provenance or source area in the Brooks Range (assumed source direction) of mainly intermediate volcanic flows (hornblende andesites), volcanic glass, and fine-grained sedimentary rock 
majnly mudstone and chert. Minor source contribution also was from acid intrusive rocks (granodiorite or quartz diorite) and rare low-grade metamorphic schist and quartzite as in the Schwatka Mountaing Devonian and pre-Devomian (RRR-252 and 239) samples. Thus, in the early Cretaceous a predominantly volcanic and fine-gxajned sedimentary provenance with minor metamorphics and acid intrusives was being weathered and eroded in the Brooks Range (supposed source area, Jure letter of Rose), and the detritus was being rapidly deposited in nearby basing southwest and northwest of the Brooks Range (now Waring Mountains and Delong Mountajns).

On the other hand, the predominant provenance for the lower Cretaceous sandstones of the Sagwon area, northeast of the Brooks Range, was predominantly low-grade metamorphies and fine-grained sedimentary rocks providing an abundant source area for quartz, muscovite, schist, quartzite, mudstone, and chert with only minor intermediate volcanics. This provenance (presumably the northeastern Brooks Range) remained the dominant source area for the upper Cretaceous rocks of the Sagwon area shedding metamorphic and sedimentary detritus into the basin northeast of the Brooks Range. Some acidic active volcanisn occurred as ash falls (admixed with sediment) in the late Cretaceous as evidenced by the occurrence of vitric tuffaceous sample RRR-L26. By late Cretaceous time the low-grade metamorphic and sedimentary provenance also became the predominant source material for the sandstones forming jn the Waring basin southwest of the Brooks Range.

The pre-Devonian and Devonian micaceous quartzite samples collected in the Schwatka Mountains (and presumably in the Baird Mountains) may be the type of metamorphic source area that provided low-grade schist and micaceous quartzite to the Waring basin. Thus, there appears to be a major change in type of source material for sandstones in the Waring basin 
from volcanics in early Cretaceous to metamorphics in late Cretaceous

(perhaps the lava flows were stripped away by erosion exposing the underlying older metamorphics).

The Devonian sandstones (Group V) of the Schwatka Mountains also may have been partly a source for quartz in the quartz-rich sandstones of the upper Cretaceous of the Waring basin, but it is not conclusive as nost of the quartz in the upper Cretaceous is subangulax to angular. The grains appear to be too angular to have been recycled from older sedimentary rocks.

The source terrain for the Devonian gamples (Neurokpuk, PrecambrianSilurian?) appears to have been chert-rich (ei ther from gedimentary chert beds, that is, modules from limestone, deep-water bedded cherts, or from devitrification of acidic rolcanic glass). Minor sources were finegrained sedimentary rock (mudstone), low-grade metamorphics, volcanic flows, and tuff sources. The early Cretaceous rhyodacitic - dacitic porphyry could have been the type of source material for mosaic quartz or chert clasts (devitrified acidic volcanic glass groundrass) found in the upper Cretaceous rocks of the Waring basin (if these intrusions do not intrude the upper Cretaceous rocks). Thus, there were acidic rhyodacitic intrusions in the Waring basin in early cretaceous time and low-grade to greenschist metamorphism during the pre-Devonian and Devonian.

\section{Compositional Maturity - Relief and Climate:}

Compositionally, the lower Cretaceous rocks of the Waring Mountains are immature (abundant rock fragments and unstable minerals with low quartz content), the Jurassic-Cretaceous rocks northwest of the Brooks Range and in the Delong Mountains are immature to mature, and the upper and lower Cretaceous rocks of the Sagwon area, northeast of the Brooks Range, and the upper Cretaceous of the Waring basin are mature (enriched 
in quartz and chert, low in rock fragments and unstable minerals). The Devonian sandstones are compositionally suparmature (mostly quartz and chert) to immature. Thus, the low mineralogical maturity and coargeness of the Jower Cretaceous of the Waring basin, some Devonian, and JurassicCretaceous suggest sedimentary detri.tus was derived from a rugged source terrain with oteep relief (hills, nountains, bigh stream gradients) in a temperate clinate where at times mechancal weathering dominated over chemical weathering (as in winter) to produce abundant mechanically released chemically unstable coarse-grained mineral and rock fragments. Rapid erosion due to steep relief resulted in rapid removal and transport of the unstable detritus to depositional basing before any extensive chemical breakdown of the rock fragments to clay covid occur. The finer grain size and higher compositional maturity of the upper and lower Cretaceous of the Sagwon area northeast of the Brooks Range and the upper Cretaceous of the Waring basin suggest the sediment was derived from moxe low-lying source areas (low or gently rolling topography, low stream gradients) in a wamer, moxe humid temperate to tropical(?) climate which resulted in extensive chemical destruction of most of the unstable mineral and rock fragments and breakdown to clay; thus enriching the sediment in fine-grained quartiz and chert. Slow erosion and removal due to the effect of gentle topography enhanced the chemical breakdown effects on the unstable detritus. One of the Devonian samples from the Schwatka Mountains appears to be derived from a source area with steep relief and a temperate climate. The other sample suggests derivation from a low or gently rolling source area in a warmer, more humid climate. More samples are needed to generalize. 


\section{Depositional Enviroment and Transporting Mechanism:}

The general angularity, poor sorting, and in some cases abundance of original matrix of the ear'ly Cretaceous samples (Groups I, IV, and II) of the Waring basin suggest that these sandstones were probably deposited in a rapidly subsiding basin (geosyncline?) under rapid burial conditions (that is, high rates of sedimentation) with little or no prolonged current reworking as in a surf or eolian environment. The soft mudstone clasts may be penecontemporameous rip-ups of the mud bottom by current scour. The soft mud clasts would not have survived deposition in an environment with prolonged agitation such as surf. The larger rock fragments tend to round with minimal transport. The coarsest sandstones in both groups (medium to granule size) generally have no clay matrix (arenites). Some have oriented clasts suggesting they underwent some current winnowing of fines and that they were deposited by high energy currents (enough competence to move granule size fragments). Probable environments to produce detritus of this textural maturity are deltaic or fluvial(3) channels, offshore maxine (near sea cliffs), littoral sands, or deepwater below wave base. The finer grained sandstones tend to contain more clay matrix. The finer grain size and laminations suggest they were deposited by weaker currents (low flow regime) in a low energy enviroment such as deltaic overbank, lagoonal swamp, protected bay, estuarine, and low energy tidal flat, or offshore deep marine (below wave bage). The Jurassic-Cretaceous samples from northwest of the Brooks Range and from the Delong Mountains, the Devonian samples from the Schwatka Mountajns, and the upper Cretaceous of the Waring basin are similar texturally (alightly better sorted and higher quartz content) to the early Cretaceous of the Waring basin and were probably deposited in similar enviroments. 
Although the sandstones of these groups are better sorted and contain higher percentages of quartz than the lower cretaceous of the Waring basin suggesting more prolonged wimowing and reworking, only Jurassic.. Cretaceous sample DWA-374 and Devomian sample RRR-276 which are texturally: supermature (some vell-rounded quarti grains, well sorted, no matrix) may have been deposited in an offshore bar or on a beach or strandline.

Only the lower and upper Cretaceous samples of the Sagwon region northeast of the Brooks Range appear to be of a different depositional. origin. The general overall fine grain size, fair sorting, high abundance of quartz and muscovite, and general lack of matrix in the arenites suggest deposition in an offshore Iittoral enviroment or deltaje environment (for example, barrier bar, bay mouth bar, or distributary chamnel) in which there was more current reworking to produce winnowing of the fines, better sorting, and abrasional removal of softer unstable Iithic rock fragnents than in other suites. Deposition was still in a relatively low energy enviroment to allow buoyant muscovite flakes to settle out with quaxtz. The occurrence of relatively soft schist and mudstone clasts in the sandstones and the grains are too angular to have been deposited in high energy and abrasional surf or eolian zones. The grains would have been rounded in these environments and the soft sedimentary and metamorphic clasts would have been destroyed. However, the high abundance of quartz in these Cretaceous deposits compared to other suiteg does suggest more abrasion occurred resulting in the destruction of unstable softer mineral and rock fragments than in the other lithic-rich suites and thus relatively an enrichment of the sediment in quartz and chert in the upper Cretaceous rocks of the Sagwon area. The high abundance of quartz in the Cretaceous of the Sagwon area may also reflect more 
abundant quartz in the source area than for the other suites and/or the very fine- to fine-grained sand size of the sample in which in general there always a lack of rock fragments at this size (they are destroyed into clays before breakdown to this fine size).

Some of the very fine-grained sandstones are original clay-rich (wackes) and were probably deposited in a lower energy environment (such as lagoonal, back bay, or swamp) where fine clay could settle out. There was little winnowing or reworking accompanied by rapid buxial.

Sample RRR-LI6 (upper Cretaceous of Sagwon area) contains a concentration of carbonaceous plant natter in Iaminae suggesting rapid burial which protected the plant matter from oxidation and decay. Upper Cretaceous vitric turf or tuffaceous sandstone sample (RRR-426) contains abundant glass shards suspended in a detrital clay matrix (50\%) suggesting an occurrence of active volcanism in late Cretaceous time. Shards normally are not recycled from older tuffs because they are readily destroyed by abrasion and chemical weathering. Apparently the glass shards settled from an ash fall into a low energy maxine environment (e.g. deep or shallow marine offshore below wave base, protected bay, or lagoonal) and were adrnixed with terrestrial clay through weak current action. If the tuffaceous sandstone was derived from ash falls, then this unit is probably of uniform thickness and is widespread. Thus, this unit may be a distinctive marker bed in recognizing stratigraphic position in the upper Cretaceous of this area.

\section{Diagenetic History:}

The lower and upper Cretaceous rocks of the Sagion region and the upper Cretaceous rocks of the Waring Mountains and Devonian samples of the Schwatka Nountains have undergone similar diagenetic histories. There has 
been moderate to extensive compaction as indicated by the crushed and contorted appearance of muscovite flakes, schist and mudstone clasts, and carbonaceous plant fragments between quartz grains, and by some interpenetration of adjacent quartz grains by pressure solution to produce serrated boundaries (micro-stylolites). There is some replacement of quartz boundaries by matrix. Minor or rare quartiz over. growths in some samples were produced on some quartz grains by precipitation of quartz from silica-enriched groundwater perhaps during preasure-solution of grains. Stylolites (as in limestones) produced by pressure-solution are displayed in the upper Cretaceous tuff sample (RRR-426). Rock fragments (volcanic, some schist) and feldspar have been partly altered to micaceous clay (sericite), greenish celadonite or chlorite, or opaque iron oxide forming indistinct grain and matrix boundarjes. The celadonite matrix in some wackes is authigenie in origin.

Because of the high quartz content and low percentage of compositionally ungtable mineral and rock fragments (particularly volcanics), the diagenetic alteration is not as severe as in the lower cretaceous rocks of the Waring basin or in the Jurassic-Cretaceous rocks northwest of the Brooks Range. The shards in the upper Cretaceous tuff sample have altered to the zeolites heulandite and analcime(?).

Oxidation of iron minerals (magnetite?) to hematite and/or remobilization and precipitation of opaque iron oxides (hematite, leucoxene) by groundwater to form partial pore filling cenent have occurxed.

Groundwater enriched in $\mathrm{CO}_{2}$ and $\mathrm{Ca}$ extensively precipitated carbonate as pore filling cement (rarely as rhombs) with some replacement of quartz grain boundaries by carbonate minerals.

The Jurassic-Cretaceous samples of northwestern Brooks Range and the Delong Mountains have undergone a simflar diagenetic history except that 
compaction effects are not as obvious and there has been more extensive diagenetic alteration of the groundmass in volcanic rock fragments, and complete replacement of clasts of unknown original composition by chlorite, leucosene, brown clay, and less commonly carbonate or hematite. In sample RRR-310 later fracturing after lithification produced fractures which were infilled with carbonate. In contrast to the upper Cretaceous samples of the Waring Mountains and the lower and upper Cretaceous of the Sagwon area, the volcanic rock fragment-rich lower Cretaceous rocks of the Waring Mountaing (Groups, I, II, and IV), lack carbonate cement and have undergone more extensive alteration (particulaxly RRR-391 and 392). Compaction effects are not as severe or at least not as obvious in thin section. The groundmass of most of the volcanic rock fragments has been altered to greenish celadonite, sometimes chlorite, and/or chlorophaeite (yellowish mineral). The result is the obliteration of rock fragment boundaries in which the fragments seemingly merge with the authigenic brown clay or greenigh celadonite matrix. Hormblende remains relatively fresh. Pyroxene is partly altered to clay. Probable amygduloidal rolcanic glass alters entirely to celadonite, chlorite, or chlorophaeite with spherical amygdules infilled with radiating chlorite or celadonite. Iron minerals (ilmenite) were oxidized to leucoxene and less commonly to hematite. Leucoxene and rarely carbonate were precipitated as cement in pore spaces. Untwinned feldspar and plagioclase feldspar altered to scattered patches of sericite (particularly along cleavage planes) and rarely to carbonate. Very extensive diagenetic alteration occurred to Cretaceous? samples RRR-391 and 392 (igneous or sedimentary?, Rosé). Yet clastic rock fragments still can be seen. Some fracturing and infilling by quartz occurred after lithification is evident in RRR-392. 
Devitrification and/or alteration of the acidic glass groundnass occurxed in RRR-386 (the porphyritic rhyodacite intrusive) to produce a groundmass of microcrystalline quartz, feldspar, and chlorite. The edges of the plagioclase phenocrygts were altered to chlorite and micro-fractures produced in the solidified mass were later infilled with chlorite which in part is oxidized to hematite.

\section{General Comments:}

In reply to specific questions or comments by Bob Rosé in his letter of July 27, 1972, concerning thin sections, the following general comments are made.

\section{I -- "Samples RRR-201, 209, and 214 and DWA-299 (Croup I) are from early Cretaceous rocks of the western Waring Mountains. They were deposited in an east-vest trending basin that received most of its detritals from the Brooks Range (northward). The samples RRR-376A and $\mathrm{B}, 378,379,382 \mathrm{~A}$ and $\mathrm{B}, 383,384,393,395,397,401,402$, and 404 (Group II) were also deposited in the basin at the same time but east of the first group of samples 70-170 miles. The source area for the above samples is thought to be similar for all."}

Comment: Yes, the minoralogy of both groups are almost identical suggesting similar source areas - predominantly internediate volcanics (hornblende andesite), fine-grained sedimentary for mudstone and chert (or devitrified volcanic glass), acid intrusive (granodiorite or quartz diorite), vein quartz and minor low-grade metamorphic quartzite or quartz muscovite schist. The only difference in mineralogy is that Group I contains some biotite $(0.4 \%$ to $7.2 \%)$ and muscovite as well as a trace of micrographic quartz and quartz with tourmaline and zircon inclusions. Thus, in addition to the source terrain mentioned above for both suites, there was a biotite and muscovite source (probably low-grade biotite and muscovite schists and/or biotitemich granitic intrusive rocks) that 
contributed mica detritus in the western Waring basin but which was not prevalent in the eastern Waring basin during early Cretaceous time.

II - . "Samples RRR-266, 387, 389, 399, and 403 (Group III) are all. quartz-rich clastic rocks which are thought to be upper Cretaceous but deposited in the same eastwegt basin south of the Brooks Range. The source area appears to be a metamorphic texrane exposed. in the Baixd and Schwatka Mountains of the Brooks Range."

Comment: Yes, this upper Cretaceovs quartz-rich suite contains abundant low-grade metamorphic rock Pragnents (mainly quarta muscovite schist and some quaxtzite or gmeiss) suggeating a metamorphic provenance was the main source area for the rock fragments, strained and mosaic quartz, muscovite, and biotite in the sample.

III .. "Samples RRR-391 and 392 (Group IV) are fron the same bagin but are closely associated with igneous intrusive and extrusive rocks. It is hard to tell if the rocks collected were igneous or sedimentary or combination of the two."

Comment: Sedimentary origin. This section study shows that these are clastic sedimentary rocks not intrusive jgneous. They contain a mixture of recognizable volcanic and sedimentary rock fragnents and mineral constituents not possibly found in combination in any igneous rock. However, due to extensive diagenetic alteration and abundant authigenic matrix in RRR-391 and 392 and the extremely fine grain size of RRR-392 (siltstone wacke), the difficulty in distinguishing the origin in the field is easily understandable. It was difficult even in thin section due to the extensive alteration. RRR-391. (a medium-grained lithic wacke) is compositionally and texturally similar to the lower cretaceous suite of the Waring basin (rolcanic rock fragments, chlorite/celadonite replaced vesicular clasts, abundant plagioclase feldspar, low quartz content, mudstone fragments and pyroxene)。 RRR-391 is quartz-rich as are the upper Cretaceous rocks of the Waring Mountains suite. However, the distinctive 
muscovite flakes of the uppex Cretaceous suite is missing and RRR-2' 91 does contain hornblende found only in the lower Cretaceous suites of the Waring Mountains. My preliminary guess is that both samples are probably Iower Cretaceous in age and the high quartis content of RRR-391 reflects grain size effect on mineral distribution and abundarce.

IV - "Sample RRR-386 is an igneous intrugive that intruded the early Cretaceous rocks of the east-west basin south of the Brooks Rangen.

Comment: Sample RRR-386 is a porphyritic dacite or rhyodacite intrusive.

$V$-- "Samples RRR-276 and 359 are from a Devonian sandstone sequence cropplng out in the northwestern part of the Schwatia Mountains of the Brooks Range. Source terrane may be Neurokpuk (Precambrian-Silurian). Samples RRR-239 and 252 are both metamorphosed but 239 is thought to be pre-Devontan and 252 thought to be Devonian. Sample 252 may be the same formation as RRR -276 and 359."

Comment: Both RRR-276 and RRR-359 (Devonian sandstones) and metamorphic micaceous quartzite RRR-252 may appear megascopically similar in the field (well-indurated and quartz-rich) to have been included in the same formation. However, considering their apparently different textures, mineralogy, and origins suggested under the petrographic microscope, I am hesitant to include them in the same formation. Under the microscope, RRR-276 and 359 are obviously clastic composed of weathered and eroded angular fragments of predominantly quartz and chert and rare mudstone fragments well cemented and outlined by carbonate or hematite/leucoxene. The distinct grains are angular and poorly sorted. Pressure solution due to compaction (deep burial or tectonic?) resulted in some interpenetration of adjacent grains and produced adjacent serrated edges, that is, a sedimentary quartzite effect. Unlike RRR-252, there is no well-defined foliation or metamorphic fabric in the sandstones such as aldgned trains of large muscovite flakes along shear surfaces, elongate zones parallel to 
shear surfaces of granulated quartz, and micro-"ptygmatic" folds. No large metamorphic flakes occur in RRR-276 and 359, nor is there carbonate or hematite cement or chert in RRR-252. Probably before low-grade regional metamorphism and extensive shearing, sample RRR-252 was a pure quartz sandstone very much like RRR-276 (though more quartz and less chert) but subsequently had been dynamically changed.

In summary, RRR-276 and 359 are quartz and chert-rich clastic sedimentary rocks that have undergone some diagenetic alteration due to burial compaction but have not undergone the extensive regional low-grade greenschist metamorphism and shearing that RRR-252 has undergone.

Therefore, these samples probably should not be considered from the same formation (unless this sample RRR-252 is from a shear zone in that formation).

VI -- "Sample RRR-348 is probably Devonian and should be compared with RRR-359 for similarity."

Comment: RRR-359 and 348 are similar in grain size, sorting and angularity of framework minerals, but RRR-359 has no matrix whereas RRR-348 contains abundant authigenic(?) clay matrix (14.5\%) and has a preferred orientation of mineral clasta.

Even though RRR-359 and 348 have the same grain size and sorting, there are striking differences in the mineralogy and rock fragments. RRR-348 contains abundant clinopyroxene (20.3\%), altered volcanic rock and tuff fragments (2.6\%), trace of plagioclase feldspar whereas RRR-359 does not contain any of these mineral and rock fragments.

Traces of schist and siltstone rock fragments and green tourmaline occur in RRR-359, but not in RRR-348. RRR-348 has abundant authigenic micaccous clay matrix (indistinct grain boundaries to volcanic rock fragments) whereas RRR-359 has no matrix. 
Both RRR-359 and 348 contain quartz, chert, muscovite or sericite, and carbonate altered replaced clasts, leucoxene, and similar amounts of mudstone rock fragments. But the relative abundance of these minerals in each section is strikingly different (particularily in the amount of quartz and chert, mosaic to normal quartz). The abundance is reversed in the two samples.

The quartz and chert-rich mineralogy of Devonian sample RPR-359 is more similar to the mineralogy of the upper Cretaceous rocks of the Waring Mountains, whereas the abundance of volcanic rock fragments, pyroxene, and low quartz, and chert content of Devonian sample RRR-348 is nore similar to the mineralogy of the lower Cretaceous rocks in the Waring basin. My educated guess based on the strikingly different mineralogies is that they are not related.

RRR-359 has undergone extensive carbonate replacement of clasts of unknown original composition. Perhaps these clasts were once pyroxene and volcanic fragnents once similar to RRR-348. However, this is unlikely.
VII -. "Samples DWA-374 and RRR-323, 333, and 336 are all Jurassic- Cretaceous graywacke-type rocks deposited just north of the front of the western Brooks Range. They had their source south from the Range. RRR-310 is thought to be of the same age but is found within the Delong Mountaing of the western Brooks Range."

Comment: RRR-310 from the Delong Mountajns is coarser grained (granule conglomerate) than the other Jurassic-Cretaceous sandstones; but like the other coarse Jurassic-Cretaceous sandstones, it is poorly sorted, lacks matrix, and the rounding of the rock fragments is high. Being coarger grained than most of the Jurassic-Cretaceous sandstones, the Delong Mtin. sample contains a larger variety and generally greater abundance of rock fragments than the other coarse-grained Jurassic-Cretaceous sandstones. But the compositions of the clasts are the same kinds and occur in only 
slightly different abundanees, that is, intermediate volcanic rock fragments and sjltstone clasts are more abundant than mudstone clasts in the Delong sample. The Jurasic-Cretaceous samples and the Delong Mountains sample contain a carbonate cement. A.though tho JurassicCretaceous suite appears to be graywacke in the field, microscope examination reveals a very low content of matrix (less than $4.2 \%$ ); thus, they are arenites. They also lack metamorphic clasts and mica, the presence of which would have classified them as graywackes under an older classification.

VIII -- "The next group of thin sections comes from rocks in the foothills of the eastern Brooks Range. Samples RRR-L12, 413, 414, 418, 421, 424, 426, and 431 are fron the upper Cretaceous southwest through southeast of Sagwon. They vere all sourced from the Brooks Range. Samples RRR-435 and 440 are early Cretaceous and should be similar to each other. They are probably sourced from the Brooks Range and are probably strandline deposits as are the others from the Sagwon area."

Comment: The variety and relatjve abundance of minerals, as well as textures (size, soxting, rounding, and percentage of matrix), in the upper Cretaceous samples and early Crotaceous samplos (RRR-435 and 440) from the Sagwon area are very similar. These similarities suggest that this basin received sorted detritus from a predoninantly low-grade metamorphic (quartz mica schist and quartzite) and fine-grained sedirentary (mudstone, chert, and vein quartz) provenance from early to late cretaceous times. There were active acidic rolcanic emptions near the basin during the late Cretaceous as evidenced by rhyodacitic vitric tuff sample RRR-426. A volcanic lava flow terrane (basalts and andesites) as well as some possible acid intrusives (granodiorite or quaxtz diorite?) contributed minor detritus. 


\section{PETROGRAPHIC METHODS}

Each of the 47 thin sections underwent the following analysis: A detailed petrographic study was made of the textures and mineralogy of the slide using 3.5X, 10X, and 50X Ienses. Time required ranged from one to three hours. Observations were recorded on petrographic sheets (enclosed with this report) of each sample. Plagioclase feldspar composition was determined by extinction angles in albite twins by Michel-Levy's method and interference angles. A minimum of 8 determinations was made in each slide that contained significant amounts of plagioclase. The mineralogy of untwinned feldspars (orthoclase or $k$-spar versus untwinned plagioclase feldspar) was difficult to determine because the index of refraction of the mountingmedium is not known. Staining for k-spar or orthoclase in uncovered thin sections would solve this problem. Most minerals were determined by their characteristic optical properties; color, cyrstal form, relief, interference figure, 2V, extinction angles, twinning, and cleavage.

Measurement of grain size, sorting, and rounding of grains in each section was accomplished using a Bausch and Lomb projector. Each slide image was projected on a white sheet of paper at a known magnification. A grid of known magnifjcation was placed over 300 grains to measure the minimum diameters (c-axis, that is, the size that would fall through a sieve) and average sizes in order to determine the average grain size and the range of sizes (as a measurement of sorting) in each sample. If the range of grain sizes varied over four Wentworth size classes, the material was considered poorly sorted; over three classes - fair sorting, and over two sizes - well-sorted. Rounding and shape was estimated using 
Power's scale on 100 randomly chosen grains. The measurement of grain sizes in thin section yields a minimum size because of the twodimensional bias and all the samples are actually coarser grained.

Point counting: a minimum of 600 points per section was used in this analysis (range: 610 to 1000). A mechanical point counter with a $0.1 \mathrm{~mm}$ by $0.1 \mathrm{~mm}$ grid was used. Before point counting, each section was examined and the best part of the rock slide was outlined with blue washable fine lined marking pen. This was done to eliminate measuring artificial porosity along the too thinly ground edges of the section. The quality of each section is reported at the top of each description sheet. In general, they were good, but the amount of area each rock slide covered on each section varies from slide to slide. Hence, on some sections where only. half of the slide was covered with the rock sample a $0.1 . \mathrm{mm}$ by $0.05 \mathrm{~mm}$ grid was used in order to measure more than 600 points. Point counting was done under crossed nicols and under plain light。

The dominant minerals (greater than 1\%), visible porosity, and mount of matrix and cement was point counted on each slide. The data were summed, and the number of points for each factor was calculated as a percentage of the total. Visible porosity point count measurements are only an approximate andrelative measurement, of true porosity because real porosity is difficult to measure in thin section. In addition, plucking and grinding probably increased the true porosity. True porosity would be best measured in the laboratory using a rock sample rather than in thin section. 
The most accurate point counts and descriptions are of the unaltered coarse-grained samples with distinct grain boundaries. The fine-.grained and altered sandstones were harder to point count especjally in determining amount of matrix versus framework grains. In these slides the framework grains contained vague grain boundaries that merge with the authigenic matrix.

After each sample was point counted, the proportions of matrix, quartz and chert versus lithic fragments versus feldspars were plotted on the triangujar diagrams of Williams, Turnex, and Gilbert (1953) and the samples were subsequently classified. Two summary diagrams of all the sections are included in the report. I included some adjectives to further classify the samples such as fine-grained, and carbonate cemented. Initially the sections were grouped according to grain size, occurrence of abundant volcanic rock fragments and feldspar versus abundant quartz and schist fragments. Rosé's letter of July 27 outlining the field locations and some field description of the samples resulted in grouping the samples based on age and field location (Groups I - IX).

A mineralogical and textural summary of each group was prepared using the petrographic reports (included in this report) on each sample in the group. The mineralogy and textures of each group were compared with other groups of samples studied. Finally a shortened summary with conclusions of the most significant mineralogical and textural characteristics and differences among the groups was prepared. 


\section{Recognition of rock fragments and matrix:}

1. Volcanic rock fragments are distinct clasts with abundant microlites of plagioclase feldspar. Textures $a, b$, and $c$ below are best seen in the thin sections of the lower Cretaceous rocks of the Waring basin. Various textures present include:

a. Porphyritic clasts - large plagioclase, hornblende, or more rarely pyroxene phenocrysts in a groundmass of feldspar microlites or altered celadonite, brownish clay, or opaque iron oxides.

b. Pilotaxitic - parallel or subparallel flow alignment of plagioclase microlites in an altered greenish celadonite chlorite, brownish clay, or opaque iron groundmass. This texture is commonly found in volcanic flows of intermediate composition, such as andesites.

c. Intersertal - random orientation of feldspar microlites in some cases with opaque iron oxides (magnetite or leucoxene), pyroxene fragments between microlites, or in a celadonite, brownish clay, and chlorite groundmass. Most of the feldspars are andesine in composition. Those with hornblende phenocrysts suggest that most of the volcanic rock fragments were derived from hornblende andesites although some basalt may occur.

d. Greenish fibrous celadonite or chlorite replaced clasts with amygdules filled with radial chlorite or celadonite needles probably altered volcanic glass. Some with many tube-like amygdules may be altered pumice. 
2. Metamorphic rock fragments (best developed in the thin sections of the upper Cretaceous rocks of the Sagwon area):

a. Quartz mica schist - generally elongate clasts with parallel aligmment of bunches of muscovite or chlorite flakes (shows aggregate polarization); some mosaic quartz between flakes.

b. Quartzite (may be gneiss) - elongate clasts of mosaic strained quartz; some with straight contacts; other clasts with sutured contacts; the polycrystalline quartz units are generally elongate in the longest direction of the clasts and contain parallel or sub-parallel muscovite or chlorite flakes outlining foliation.

3. Acidic intrusive plutonic rock fragments (granodiorite or diorite?) these clasts are best seen in the coarse-grained lower Cretaceous rocks of the Waring basin and consist of large interlocking crystals of quartz, albi.te twinned plagioclase feldspar (albite and oligoclase), rare green hornblende, and untwinned sericite altered feldspar (presumably orthoclase or potash feldspar). A few pieces of micrographic quartz (a checked intergrown pattern of quartz and feldspar) occur in some individual quartz grains (not associated with intrusive rock fragment samples). These micrographic quartz fragments probably were derived from graphic granite that contained quartz with the intergrowth pattern.

4. Sedimentary rock fragments:

a. Mudstone - elongate shape with irregular edges consisting of cryptocrystalline dark brownish clay is the most common; rarely with silt size angular quartz or muscovite. 
b. Some brownish mudstone clasts are laminated with dark iron oxides (most commonly leucoxene) or carbonaceous matter. Some contain mosaic quartz...filled spherical cavities (recrystallized radiolaria?) which the dark laminae wrop around may be deep water mudstone source. Most abundant in the upper Cretaceous rocks of the Sagwon area and the JurassicCretaceous rocks.

c. Argillite or slate - dark cryptocrystalline brownish clasts that show aggregate polarization.

d. Siltstone - elongate clasts composed of predominantly silt sized angular quartz, some feldspar, and muscovite flakes in a fine-grained clay or opaque iron oxide matrix.

e. Fine-grained sandstone - rare, in coarser sandstones; same description as siltstone except quartz is fine sand size.

5. Chert - commonly as equidimensional angular clasts composed of clear cryptocrystalline quartz; rare euhedral fejdspar phenocrysts occur in some chert clasts suggesting chert is of a volcanic origin from devitrification of acidic volcanic glass. Some chert clasts also contain fragments of mica of celadonite or opaque iron oxides (leucoxene). 
Thin sections included in Group I: RRR-209, -214, and DWA-299

Thin section sample RRR-201 was not ineluded in the thin sections received.

Age and field relationships (Rose): Early Cretaceous; Western Waring Mountains, deposited in an east-west basin south of the Brooks Range; source area to the north in the Brooks Range.

\section{TEXTURE:}

These samples are texturally similar. They are texturally mature medium-gxained sandstones, contain little or no matrix, range from poorly sorted (RRR-209, DWA-299) to well-sorted (RRR-2IL), and are composed mostly of angular to subangular euhedral or prismatic feldspar and equidimensional quartz. Some large volcaric fragments are well -rounded due to theix lower resistance to abrasion than smaller quartz or feldspar. No preferred orientation was observed. In general, the porosity is low $(0.9 \%$ to $4.3 \%$ ) and is intergranulax or less commonly intragsanular. The Low porosity is due to an aburance of carbonate cement infilling pores. These sandstones probably would not make good petroleun reservoirs (assuming these are representative and are fresh samples; in the subsurface may bo different. 
MTNERALOGY:

These early Cretaceous samples are similar in mineralogy to the early Cretaceous samples of Group II which were collected in the Waring basin 70 to 1.70 miles to the eagt.

As in the Group II samples the quartz content (strained and polycrystalline varieties) is low (0.9\% to $33.7 \%$; average: $18.0 \%)$. A large variation of feldspars includes plagioclase feldspar (albite and pericline twinned; oligoclase and andesine), gome untwinned feldspar (orthoclase?; range: trace to $53.8 \%$; average: $19.6 \%$ ), and a rare occurrence of microcline in RRR-209 and DWA-299. Hornblende (6\%) and yellowish to colorless clinopyroxene (4\%) also occur in some sections (RRR-209 and DWA-299, respectively).

Heavy minerals include magnetite/ilmenite, hematite, leucoxene, and, in $R R R-214$, apatite, zix $x^{\circ}$ on, and green tourmaline. The alteration product, chlorophaeite (yellowish fibrous mineral) and greenish chlorite/ celadonite also occur completely replacing clasts (up to $5.8 \%$ of the rock). Some clasts contain chlorite replaced anygdules.

The most abundant rock fragment type is volcanic flow fragments with pilotaxitic and intergertal textures (range: $3.0 \%$ to $22.6 \%$; average 13.8\%) similar to that described for Group II. One unusual vol.canic rock type contains bladed mierolites of zeolites(?) and mosaic quarta. Chert ranges from a trace to $5.2 \%$ (average:2.0\%), followed by a low content of siltgtone and/or mudstone (range: $1.4 \%$ to $5.6 \%$ average: $2.4 \%$ ), acid plutonic clasts, granodiorite in $P R R-209(0.6 \%)$ and in DWA-299 (2.9\%), and a trace of quartitite and quartz mjca sehjst.

\section{Distinctive characteristics:}

This suite differs from the Group II suite in that two of the three samples contain some biotite $(0.4 \%$ to $7.2 \%)$ and muscovite $(0.6 \%)$. A trace of micrographic quarta and toumaline and zircon inclusions in some quartz grains also occur. The samples are cemented with and partially altered to carbonate (range: $17.7 \%$ to $30.9 \%$; average $24.8 \%$ ) and contain little or no celadonite matrix. No quartz overgrowths were observed. 
PROVENANCE OR SOURCE AREA: - The Brooks Range?

Similar to that of the lower Cretaceous rocks of Group II

1. Major source: Volcanic Plows - intermediate (andesite), perhaps basaltic to yield pyroxene and some rolcanic rock fragments; some volcanic glass altered to clasts of celadonite/chlorite.

2. Important source - acid intrusive - granodiorite; source for quartz, biotite, muscovite, oligoclase, and untwinned. feldspar (orthoclase).

3. Fine-grained sedimentary rock $=$ source for siltstone and mudstone clasts (some may be penecontemporaneous ripmups).

4. Very minor source - low-grade metamorphics ss source for quartzite or gneiss and quartz mica schist; could be source for sone strained quartz and biotite.

5. Chert - sedimentary chert beds or devitrified acidic rolcanic glass as some contain phenocrysts.

6. Mosaic quartz - vein quartz; some micro quartz veins in chert and mudstone fragments = source area for vein quartz; some mosaic quartz may be quartzite. 
Relief and Climate:

The three sanples of this sujte are compositionally immature, that is, they contain abundant unstable lithic and mineral clasts (mainly feldspars). This imnaturity suggests that the nearby(?) source area was rugged with hills, cliffs, mountains, and steep stream gradients in a temperate or arctic(?) climate so that various rock sources could be physically broken up into fragments and small pieces and rapidly removed from source area and transported before chemical weathering broke down unstable rock and mineral clasts into clays.

\section{DEPOSTTIONAL ENVIROMENT AND TRANSPORT TNG MECHANISM:}

Lack of matrix, medium grain size, angular minexals, and poor sorting in general suggest a rapid mixture of heterogeneous source with winnowing only of clays. The general angularity of the grains suggests littie or no reworking of mineral clasts and rapid burial after reaching depositional envi ronment (i.e. rapidly subsiding basin with high rates of sedimentation geosyncline). The larger and softer volcanic and plutonic grains are in some cases well-rounded with minimal transport. The medium grain size suggests high energy current transport. Probable environment to produce detritus of this textural maturity are fluvial, deltaic channels, offshore marine - littoral, or deep-water neritic(?) below wave base. 
DIACENETIC IISTORY:

Exact order of history is not discernible in thin section.

1. Compaction minor - little pressure solution of quartz or contortion of micas.

2. Carbonate replaced parts of quartz, mosaic quartz, and groundmass in rolcanic clasts.

3. Feldspars altered to scattered patches of sericite and carbonate.

4. Alteration of groundnass in volcanic rock fragments and other unidentifiable completely altered clasts to yellow fibrous chlorophaeite, chlorite, and celadonite.

5. Corrosion of pyroxene fragments.

6. Oxidation of some magnetite/ilmenite to leucoxene/hematite aggregates.

7. Precipitation of some carbonate cement in pores and in fractures across grains = Iithification. Sample RRR-214 has undergone extensive carbonate alteration.

\section{CLASSTFICATION (Gilbert, 195/):}

The three samples of this suite are either lithic or subfeldspathic Iithic arenites (mostly volcanic, RRR-209, DWA-299) or arkosic arenite (abundant plagioclase feldspar, RRR-21.4). See sumary triangular diagran. 
PETROGRAPHTC REPORT

UNTON OTI COMPANY

North SIope Sanples

Sample No. RRR-209

Analyst: A. R. Niem

Rock Name: medium-grained lithic arenite (mostly volcanic)

Number of points counted: 615

Date: August 2, 1972

Slide Quality: good, except thin edges

TE XTURE

Framework:

Porosity: 4.3\%; Type: intergranular and graxular

Median grain size: medium sand

Sorting: fair

Shape and rounding: quartz and rock fragnents are equidimensional in general and angular; a few volcanic rock fragnents well-mounded due to their relative softness.

Textural Maturity (Folk): mature: 10 little or no natrix.

2. fair sorting

3. but most grains angular

Preferred orientation: none

\section{MINERALOGY}

Framework minerals:

Quartz: 19.6\%; Types: trace of micrographic quartz; angular equidimensiona quartz mostly with undulatory extinction; some quartz with rutile needle inclusions; mosaic quart $"=$ coarse- and fine-grained strained quartz with sutured contacts (mi crostylolites); some composed of long bladed crystals of strained quarti (probably vein quartz); rare well-rounded grain

Feldspar: 5.6\%; Types: plagioclase feldspar as euhedral angular prisms; altered to sericite and albite twinned; oligoclase and andesine composition; untwinned feldspar (orthoclase?) -

prismatic, euhedral angular; altered to carbonate and sericite microcline as partly rounded equidimensional

clast with microcline twinning

Micas: 5.8\%; Type: chlorite, celadonite

Amphiboles: $6.8 \%$; Type: hornblende

Heavy minerals: trace; Type: maguetite/ilmenite as small partly rounded clast 
Sample No. RRR-209 continued ...

Rock fragments:

Chert: $5.2 \%$; cryptocrystalline quarto; chalcedony or chlorite in a series of radiating fibrous arrays (spherulites) in one clast (altered volcanic. glass?). Some chlorite replaced clasts with anygdules.

Volcanic: 22.6\%; Types: aphanitic and coarse-ugrained intermediate volcanic flow lithics consisting of pilotaxitic aligrment of plagioclase crystals (Carlssbad twiming) with celadonite green groundmass and some with magnetite/leucoxene in the interstices; other clasts have a random orientation of plagioclase microlites (intersertal); sone clasts are densely packed with microlites of feldspars; in others a fow euhedral microlites in a eryptocrystalline groundmass of celadonite green clay or dark opaque clay or iron oxide; one polcanic clast with tiny hornblende microlites;

a fourth type of volcanic fragment consists of bladed microlites of irregular geolites (?) intermised with nosaic quartz (looks like bladed vein quarta except that magnetite or celadonite

Quartzite: trace is scattered in the matrix).

Siltstone/mudstone: $5.6 \%$

Plutonic: $0.6 \%$ as one clast composed of coarse sand sized crystalline intergrowth of plagioclase (oligoclase) feldspar (albite trinned) and quartz (the quartz contains inclusions of light green tourmaline prisms)

Compositional Maturity (Folk): imature: many unstable volcanic fragments

Diagenetic alteration: I. Scattered patches of sericite replaced parts of plagioclase feldspars;

2. Scattered patches of carbonate replaced mineral clasts and occurs in matrix

3. Scattered irregular patches of fibrous greenish chlorite/celadonite replaced volcanic clasts and occurs in matrix.

Matrix: ( $<.03 \mathrm{~mm}$ ) Trace of authigenic matrix.

Type: not all the boundaries of the rolcanic rock fragments are distinct due to alteration to greenish clay celadonite which in a sense is acting as an authigenic matrix

Cement: 17.7\%; none as overgrowths

Types: carbonate as irregular aggregates filling pores or replacing grains between framework clasts;

hematite/leucoxene as irregular opaque coatings on some of the rolcanic rock fragments, feldspars, and quartz grains 
Sample No. RRR-209 continued...

\author{
SURMARY \\ INFERENCES AND CONCLUSIONS
}

\title{
Provenance:
}

Rock types: 1. Predominantly intermediate volcanic source consisting of andesitic flows and acidic rolcanic glass source for hornblende, plagioclase feldspar (andesine), devitrified spherulitic chert and chalcedony clasts and for the aburdant lithics. Some rolcanic clasts have bladed micro quartz veing that could be the source for the bladed vein quartz clasts that are abundant. Some basalt(?) source.

2. Minor source = netamorphic rock for trace of quartzite or gneiss and for the strained quartz and polycrystalline or mosaic quartz

3. Minor source $=$ fine-grained sedinentary rock = sil.tstone and raudstone or shale; micro vein quartz cutg the finegrained mudstone or shale clasts, could be vein quartz source for the large clasts of mosaic quarto

4. Chert $=$ sedimentary nodules in limestone or deep-sea bedded chert; some are devitrifjed acidjc volcanic glass as the chert contains plagioclase microlites; micro vein quarti in chert $=$ could be the source for mosaic quarta clasts

Relief: Steep relief such as hills, cliffs, and mountainous (not lowlands); rapid erosion, deposition, and burial before chemical decomposition could occur.

Climate: temperate (with winters) or arctic(?) climate for mechanical weathering to prevail over chemical weathering at times to produce many unstable rock fragments.

\section{Depositional Enviroment and Transport Mechanism:}

Current transport winnowed out the fines and produced some sorting. Fairly high energy to transport such medium-grained clasts (river or littoral currents). Rapid deposition and burial before any reworking could occur (such as in fluvial, marine offshore, subsiding geosynclinal trough). Little abrasional rounding (not surf zone). Some soft large volcanic clasts round. easily with minimal transport.

\section{Diagenetlc history:}

1. Plagioclase feldspar altered to sericite.

2. Compaction and squeezing grains together. Pressure solution of quartz minor.

3. Devitrification of rolcanic glass to spherulites of chlorite, chalcedony, and chert.

4. Alteration of groundmass of many rolcanic rock fragments to celadonite and chlorite. Alteration of rock fragment boundaries.

5. Chlorite and carbonate completely replaced unknown minerals.

6. Precipitation of carbonate and hematite/leucoxene as partial pore filling cement = lithification. 
PETROGRAPHIC REPORT

UNION OII COMPARY

North Slope Samples

Sample No. RRR-214 Analyst: A. R. Niem

Rock Name: carbonate altered arkosic arenite

Number of points counted: 620 Date: July 24, 1972 .

Slide Quality: poor, only partial section, center plucked and empty

TEXTURE

Framework:

Porosity: 0.8\%; Type: some irregular cavities in carbonate matrix

Median grain size: mediun sand

Sorting: well--sorted

Shape and rounding: euhedral feldspars; angular

Textural Maturity (Folk): mature: 1. no matrix

2. good sorting

3. but euhedral grains

Preferred orientation: none

\section{MINERALOGY}

Framework minerals:

Quartz: $0.9 \%$

Feldspar: 53.8\%; Types: euhedral plagioclase feldspar, albite twinning, some Carlsbad twimning, some pericline twinning, some feldspars untwinned.

Micas: $7.2 \%$;ypes: biotite as large pleochroic reddish brown prismatic clasts with well developed cleavages; some contain slivers of quartz

Heavy minerals: 1.6\%; Iypes: hematite; ilmenite/magnetite; zircon; apatite; tourmaline

\section{Rock fragments:}

Volcanic: $3.0 \%$; Types: clasts with euhedral feldspar laths in Siltstone: $1.4 \%$ pilotaxitic texture (andesites?), basalt

Compositional Maturlty (Folk): immature: many unstable plagioclase feldspar and mica minerals as well as rock fragments 
Sample No. RRR-214 continued ...

Diagenetic alteration:

alteration of edges and some centers of euhedral plagioclase feldspars to carbonate. Scattered sericite dispersed through much of the feldspar laths. Biotite edges altered to clay. Some whole fragments altered to celadonite.

\section{Cement: $30.9 \%$; no cement as owergrowths}

Types: carbonate cements feldspar framework grains together; some minor celadonite acting as cenent intergpersed with calcite; minor iron oxide cenent.

\section{STMPEARY}

\section{INFERENCES AND CONCLUSTONS}

\section{Provenance:}

Rock types: 1. Biotite = acid plutonic or metamorphic; such large flakes probably acid igneous; some biotite contains quartz blebs and reldspar = granodiorjte or schist

2. Euhedral plagioclase feldspar (andesine?) = intermediate igneous rocks, andesite tuff or flows or intrusives

3. Few volcanic clasts intermediate andesite and basalt

4. Siltstone clast = a fine-grained sedimentary source

Relief: High = rapid erosion before much chemical weathering

Climate: mecharical weathering over chemical weathering protection from chemical destruction of unstable micas and feldspars

\section{Depositjonal Environment and Transport Mechanism:}

Winnowing of fines, some current sorting, rapid deposition and burial without extensive reworking (low rounding) such as fluvial or neritic sands. Relatively low energy depositional environment as compared with surf to allow biotite to settle out.

Diagenetic history: exact order of these events not discernible from thin section

Plagioclase feldspar edges and parts of centers altered to carbonate (carbonatization). Most of feldspar cloudy with scattered sericite/clay probably formed before carbonate. Minor oxidation of iron minerals. Formation of celadonite (replaces some rolcanic rock fragments). Precipitation. of carbonate cement. Much of the carbonate cement may be replacement of volcanic lithics. Alteration of biotite to iron oxide or montmorillonite? clay. 
PETROGRAPHIC REPORT

UNTON OTI COMPANY

North Slope Samples

Sample No. DWA-299

Analyst: A. R. Nien

Rock Name: medium-grained rolcanic arenite Date: July 31, 1.972

Number of points counted: 634

Slide Quality: good

\section{TEXTURE}

Franework:

Porosjty: $0.9 \%$; intergrain

Median grain size: medium sand

Sorting: poor

Shape and rounding: angular quartz and feldspar; some large rolcanic fragments well-rounded

Textural Maturity (Folk): mature - 1. no matrix

2. sorting poor

3. angular to subangular clastw

\section{MTNERAIOGY}

Framework minerals:

Quartz: 33.7\%; Types: large feldspar intergrowth in mosaic quartz; angular quartz, mostly strained variety, some straight extinction, many corroded edges by carbonate, some quartz with contorted iron oxide

inclusions; tournaline and muscovite inclusions; mosaic quartz, strained and sutured contacts some with tourmaline and zircon inclusions; fragment micrographic quartz

Feldspar: trace; Types: microcline; plagloclase feldspar; untwimned feldspar (orthoclase) altered to sericite

Micas: $9.7 \%$; Types: celadonite, chlorite; nuscovite $(0.6 \%)$; biotite $(0.4 \%)$

Pyroxene: 4.1\%; augite?

Heavy minerals: $3.6 \%$; Types: leucoxene; ilmenite/magnetite 


\section{Rock Pragments:}

Chert: $0.4 \%$

Volcanic: $16.0 \%$ Types: 1. some volcanic fragments with slender corroded feldspar laths in matrix of yellowish clay (chlorophaejte) and chlorite;

2. large dark clast with long slender Carolsbad twinned laths of plagioclase in an opaque (Jeucoxene and/or magnetite?) matrix

3. basalt rock fragments, slender crystals of plagioclase feldspar, magnetite, and augite? pyroxene between feldspars (intersertal texture?; chlorite

4. spheritic devitrified glass to celadonite/

Schist: $0.9 \%$

Quartzite: $0.9 \%$

Mudstone: $0.4 \%$

Intrusive (granodiorite?): 2.9\%

Compositional Maturity (Folk): immature: many unstable lithic fragments (plutonic, sedimentary, volcanic, and metanorphic) as well as unstable mineral grains

Diagenetjc alteration:

1. Carbonate replacing some quartz

2. Yellow brown clay replaces groundmass in volcanic rock fragments; also occurs as irregular fibrous aggregates replacing (along with carbonate) other clasts or in matrix

\section{Cement: $25.8 \%$; none as overgrowths}

Types: carbonate cements framework grains together; yellow chlorophaeite clay as irregular fibrous (sometimes with cleavage) aggregates

\section{SUMMARY}

INFERENCES AND CONCLUSTONS

\section{Provenance:}

Rock types: Source is a heterogeneous mixture of predominantly basalt and other volcanic flows and lesser anounts of low-grade metamorphics (schist and quartzite) and acid intrusives (granodiorite?) and very minor sedimentary.

I. Basalt flow = pyroxene and plagioclase laths intergrown (texture)

2. Acid plutonic (granodioxite?) = quartz intergrown with plagioclase feldspar (oligoclase); probable source for biotite, muscovite, microcline, quartz, and micrographic quartz

3. Quartz muscovite chlorite schist and quartzite = Iow-grade metamorphic (micro-vein of quartz seen in one quartzite fragment)

4. Mosaic quartz = quartz vein associated with 1 ow-grade metamorphic

5. Mudstone = fine-grained sedimentary rock or penecontemporaneous rip-up 
Sample No. DWA.299 continued...

Provenance:

Rock types: continued ...

6. Inmenite/magnetite = basalt flow or acid intrusive

7. Fibrous intergrowths of quartz and minor plagioclase intrusive? like micrographic quartz clast

8. Untwimed feldspar (orthoclase?) partiy altered = acid intrusive

Relief: steep relief to allow rapid removal of unstable detritus; predominantly mechanical weathering over chemical weathering; various rock sources could be mechanically broken up into small pieces; these rock pieces rapidly removed from source area and transported before chemical weathering destroyed fragments into clay.

Depositional Environment and Transport Mechanism:

Medium grain size and poor sorting suggest a rapid mixture of heterogeneous sources with wimnowing only of clays; ljttle reworking and rapid burial after reaching depositional environment as the quartz grains are very angular. The larger and softer volcanic and plutonic grains in some cases were well-rounded with minimal transport. Probable environment $=f l u v i a l$, offshore littoral, deltaic, or deepwater.

Diagenetic history: Exact order of history not discernible.

1. Compaction minor, no pressure solution or contortion of micas.

2. Feldspars altered to scattered particles of sericite and carbonate.

3. Carbonate replaced parts of quartz, mosaic quartz, and groundmass of volcanic clasts.

4. Alteration of groundmass in volcanic lithic clasts to yellowish mineral chlorophaeite, chlorite, and carbonate.

5. Complete alteration of unidentifiable minerals to yellow fibrous clay mineral (chlorophaeite).

6. Oxidation of some magnetite/ilmenite to leucoxene/henatite aggregates.

7. Precipitation of carbonate cement in pores and in fractures across grains.

8. Corrosion of pyroxene augite fragments. 


\section{SUMMARY - Group II}

Thin sections included in Group IT: RRR-376A, 376B, 378, 379, 382A, 382B, $383,384,393,395,397,401,402,404$ (14 samples)

Age and Field Relationships (Rose): Early Cretaceous; Waring Mountains, deposited in an east-west basin 70 to 170 miles east of Group I; source area to the north in the Broolss Range.

\section{MINERALOGY:}

In general, all the samples are similar mineralogically although the abundance of various mineralogical components and/or rock fragnents vary from one section to the next. Some of the nore rare mineralogic components do not occur in some sections. The mineralogy, arranged in order of abundance, is as follows:

Quartz: 1. Angular, strained or undulatory extinction quartz most cormon (range: trace to $23.3 \%$; average: $7.9 \%$ )

2. Mosaic or polycrystalline quartz (mostiy composed of sutured or microstylolitic and strained quartz) (range: trace to $6.2 \%$; average: $4.0 \%$ )

Feldspar: 1. (most abundant) Plagioclaso - angular prismatic shape (albite twinned); some pericline twinning; composition: oligoclase to andesine ( $\mathrm{An}_{12} \mathrm{Ab}_{88}$ to $\mathrm{An}_{32} \mathrm{Ab}_{68}$; rarer albite $A b_{02} A n_{8}$ ) (trace to 22.5\%)

2. Microcline - rare - trace in RRR-LOI, 384, 395

3. Untwinsed feldspar, partly altered to sericite; probably orthoclase or k-spar; sone could be untwimned plagioclase; need to stain or know the index of refraction of the mounting mediun.

Micas: 1. Biotite or muscovite is rare or absent - trace of biotite in RRR- 402

2. Chlorite, celadonite (fibrous green clay mineral; range: trace to $17.2 \%$; average: $10.6 \%$ ), and/or chlorophaeite (fibrous yellow clay mineral replaces volcanic(?) clasts as alteration product; range: none to $7.9 \%$; average: $6.8 \%)$; common in all sections.

Amphibole: 1. Hornblende - pleochroic green prisms; also occurs in some plutonic clasts or as phenocrysts in volcanic rock clasts; range: none to $12.9 \%$; average when present: $4.7 \%$

Pyroxene: 1. Clinopyroxene - colorless to light yellow; also oceurs in phenocrysts in a few rolcanic rock fragments; range: 0 to $6.6 \%$; average when present: $3.6 \%$ 
Rock fragments:

Chert: 1. Angular clasts of cryptocrystalline quartz, some clasts with micro quarti veins; Range: 0 to $23.4 \%$; average when present: $4.7 \%$

Volcanic rock fragments: Range: $1.9 \%$ to $61.5 \%$ average: $25.4 \%$

A. (most abundant rock type) Andesite and basalt lava rock fragnents, textural types:

1. Porphyritic - hornblende, plagioclase feldspar, or pyroxene in groundnass of celadonite, opaque iron oxides (1eucoxene), or brownish clay and with or without feldspar microlites; probably hornblende andesite; plagioclase compositions are acid andesine; some may be basalta in composition.

2. Pilotaxitic, parallel alighed microlites of plagioclase feldspar usually with a celadonite, brownish clay, or opaque iron oxide groundmass; this texture is commonly found in volcanic rocks of intermediate composition (andesite).

3. Intersextal - randonly oniented plagioclase foldspar microlites sonetimes intergrown with opaque iron oxides, more rarely pyroxenes; comonly contains groundmass of greenish celadonite or brownish to opaque clays and iron oxides.

B. Celadonite/chlorite or more rarely in some sections chlorophaeite replaced clasts of probably altered vesicular volcanic glass; Range: 0 to $8.6 \%$; average: $6.5 \%$

1. Amygduloidal - celadonite clasts with sphexical cavities or amygdules contain radiating fibrous chlorite or celadonite - may have originally been long or short tubed pumice.

Sedimentary rock fragments Range: 0 to $15.5 \%$; average: $6.0 \%$

1. Most abundant type is mudstone

a. brownish or black (opaque) clay with or without occasional silt-sized angular quartz, mica, or opaque iron oxide.

b. Brownish clay with dark black opaque carbonaceous? or iron oxide (leucoxene) laminations; some with spherical microw vugs filled with mosaic quartz (distort laminae), may be recrystallized radiolaria " deep-sea muds

2. Siltstone - minor - angular clasts with abundant siltsized angular quartz and/or muscovite or feldspar in a dark brown or opaque clay matrix.

3. Sandstone - rare wine sand-sized clasts

Igneous intrusive or acidic plutonic clasts

Range: 0 to $10.9 \%$; Average, when present: $5.2 \%$

1. Granodiorite or quartz diorite composed of interlocking crystals of quartz, albite twinned plagioclase feldspar (commonly oligoclase, sometimes albite), and, more rarely, green hornblende and untwinned feldspar (probab].y orthoclase, k-spar). 
Heavy mineralg: I. Magnetite/ilmenite (trace to few percent)

2. Hematite (trace to few percent)

3. Levcoxene (trace to few percent)

4. Colorless zircon (trace)

5. Colorless garnot in a quartzite clast in RRR-402

Metamorphic rock fragments (rare)

1. quartz mica schist - trace only in RRR-395, 402

2. Quartilte - trace onIy in PRR-402, 404; one with garnet

Matrix: Percent of matrix ranges from $0 \%$ to $34.9 \%$; averages $17 \%$. Predominantly a greenish celadonite matrix of probable diagenetic origin. This is suggested because the groundmass in many of the rolcanic rock fragments has been altered to celadonite; and in many of these clasts there are no distinct grain boundaries. Commonly the groundnass celadonite in the volcanic clasts merges with the celadonite matrix. In some sections this relationship is not clear. In most sections the framework minerals are in grain support; but in a fow fine-grained sections, there is partial matrix support for some framework clasts, also suggesting a diagenetic origin for the matrix. In some sections (RRR-376B, 378, 379, 382B, 393, 402) the matrix may be, in part, orjginal and consists of a dark to brownish cryptocrystalline clay that outlines rock and mineral clast boundaries but does not appear to have been formed from these unaltered clasts. Volcaniclastic rocks are very sugceptible to the formation of diagenetic matrix resulting in destruction of porosity - commonly poor reservoix rocks.

Cement - Percentage of cenent ranges from a trace to $26.3 \%$, average when present $=3.5 \%$. Few or no quartz overgrowths were observed. The amount of cement in this suite of lower Cretaceous rocks is quite low. It is characteristically of two iron oxide types, leucoxene or hematite, with leucoxene being the dominant variety. The cement consists of occasional opaque aggregates or filaments of iron oxides scattered throughout the sections cementing a few clasts together. Only in one section, RRR-376A, a hematite cemented granule conglomerate, is the percentage of cement high (26.3\%). Carbonate cement is lacking in this suite and occurs only as an occasional pore filling.

This suite of lower cretaceous rocks is characterized and can be distingui.shed from other rock suites by:

1. Abundance of volcanic rock fragments (some sections are composed almost entirely of volcanic rock fragments; others contain equal mixtures of mudstone, chert, and volcanic rock fragments and minor plutonic rock fragments).

2. Lack or only trace of muscovite, biotite, schist, or quartzite.

3. Lack or only trace of carbonate cement.

4. Abundance of celadonite/chlorite or chlorophaeite replaced clasts (some amygduloidal) producing a greenish hue.

5. Abundance of plagioclase feldspar particularly in the medium. grained sandstones (where unstable volcanic rock fragments are broken down mineralogically to fine grain size, feldspar becomes the most abundant mineral).

6. Low amount of quartz.

7. Occurrence of green hornblende and colorless clinopyroxene.

8. Abundant authigenic celadonite matrix; some brown clay. 
This suite of Cretaceous rocks is compositionally immature (Folk'g classification) because they contain abundant unstable rock fragments (mainly volcanic, sone plutonic, and sedimentary) and unstable minerals (plagioclase and untwimed feldspar, hornblende, and pyroxene).

PROVENANCE OR SOURCE AREA - probably Brooks Range (Rose)

1. Mainly volcanic: a. Mainly volcanic flows - most of which are intermediate in conposition (homblende andesites) source for volcanic rock fragments (pilotaxitic and inany porphyritic varieties), andesine plagioclase, hornblende, clinopyroxene; some clasts with intersertal texture - may be andesitic or basaltic in composition (can't tell)

b. Kinor altered rolcanic glass - tuffs?; source for chlorite, celadonite, or chlorophaeite replaced clasts particularly the amygduloidal varieties (pumice?)

2. Iinor source - fine-grained sedimentary rock - mainly mudstone; may be also penecontemporaneous current ripups of mud bottom; however, those with micro quartz veins are obviously derived from lithified mudstone; some possible recrystallized radiolaria in laminated clasts (deep-water mudstone - geosynclinal)

Minor siltstone provenance - source for siltstone clasts

3. Minor source, acid igneous plutonic or intrusive rock - granodiorite or quarta diorite

a. Source for plutonic clasts also for hornblende, quartz, oligoclase, and albite trinned plagioclase feldspar, and untwinned feldspar (orthoclase)

4. Rare source - metamorphic - source for rare occurrence of biotite, muscovite schist and quartzite (sone garnet grade)

5. Chert: 1. Sedimentary source; may be clasts from deep-rater recrystallized radiolarian chert beds or chert nodules weathered out of limestone beds.

2. Volcanic source; devitrified acidic volcanic glass may alter to cryptocrystalline quartz (impossible to distinguish from sedinentary derived chert). A few chert clasts, however, contain euhedral phenocrysts. of plagioclase feldspar suggesting an origin from devitrification of acidic volcanic glass groundmass.

6. Polycrystalline or mosaic quartz - may be vein quartz origin because much is clear: some chert and sedimentary mudstone clasts contain micro quartz veins filled with mosaic quartz, thus the mosaic quartz provenance is probably a fine-grained sedimentary one with quartz veins. Some nay be, however, recrystallized quartzite, e.g. strained 


\section{PROVENANCE}

6. continued ...

and sutured or microstylolitic quartz, but much of this mosaic quartz clast does not have preferentially elongate quartz as do the few quartzite clasts (these quartzite clasts also contain some oriented muscovite

- foliation).

\section{Relief and Climate:}

The compositional immaturity of this suite (great abundance of unstable mineral and rock fragments) suggests that the source areas consisted of rugged topography (e.g. hills, mountains, sea cliffs?) with steep stream gradients in a climate where mechanical weathering processes dominated over chemical weathering (at least at times, such as during winter in temperate climates or possibly strictly arctic(?) climate). The dominance of mechanical weathering would produce abundant angular lithic clasts and physically break apart unstable minerals which in an otherwise chemically dominated climate (e.g. tropical) would be altered to clays. The steep topography in the source area and along the path of transport resulted in rapid removal and transport of the chemically unstable detritus to the depositional area before any significant destruction to clays by chemical weathering could occur. 


\section{TEXTURAL CHARACTERISTICS}

The early Cretaceous suite is characterized by little to abundant matrix (range: $0 \%$ to $34.9 \%$; average $14.6 \%$ ), poor sorting, and angular mineral clasts. They are texturally jmature to nature following Folk'g classification. In general, the fjner grained sandstones contain more matrix (are wackes) than the coarse-mgrained sandstones and conglomexates which are arenites as the finer grained sandstones appear to have undergone more extensive diagenetic alteration in formation of diagenetic matrix or originaliy contained more clay matrix as a result of being deposited in lower energy environments. The coarger sandstones contain more spherical, equidimensional, prismatic clasts than the finer sandstones (most comonly angular elongate clastg) and sometimes contain some subrounded to wellrounded volcanic rock fragments (being softer and larger, they round earlier than the more abrasion resistant quartz, feldspar, and other mineral detritus). Grain sizes: two samples are very fine-grained sandstones, two are fine-grained sandstones, four are medium-grained sandstones, two coarse-grained sandstones, two are very coarse sandstones, and two are granule conglomerates.

The porosity is mainly intergranular (pore space associated with matrix or between framework clasts) or less cormonly granular (pore spaces derived from dissolved framework clasts) and is generally too low (0.4\% to 5.7\%; average: $2.8 \%$ ) for this suite of rocks to be a good potential reservoix. The porosity js low due to extensive diagenetic alteration of the volcanic clasts clogging pores and to much less extent due to minor cementation (iron oxides). Sone porosity may have been artificially produced in preparation of the thin sections.

\section{DEPOSITTONAL ENVIRONMENT AND TRANSPORTING MECHANTSM}

The general poor sorting and angularity, and, in sorne cases, original. matrix (texturally immature quality) of the lower Cretaceous samples suggest that they were rapidly transported, deposited, and buried with little or no reworking by currents such as in a surf or eolian environment. The angularity and poor sorting suggest that these rocks were probably deposited in a rapidly subsiding basin (geosyncline?) with high rates of sedimentation (= rapid burial). The textural characteristics of the coarse sandstones (medium sand to gramule size) which, in general, have little or no original matrix suggest that they underwent some wimnowing and that they were deposited by high energy currents (some oriented clastg in RRR-376A and 384) such as that found in a deltaic channel, fluvial, or offshore marine environment (near sea cliffs below wave base) whereas the finer sandstones tend to contain a little more original clay and being finer grained and sometimeg laminated (RRR-379 and LO1) suggest they were deposited by weaker currents (low flow regime) in low enexgy environments such as overbank, lagoonal, swamp, protected bay, or offshore deep marine (below wave base). 


\section{DIAGENETTC HISTORY}

The exact sequence of events is not discernible in thin section.

1. Minor compaction - grains and soft sedimentary clasts do not appeax to be crushed except in one case.

2. Alteration of plagioclase and untwinned feldspax to scattered patches of sericite (particularly along cleavage planes) and more rarely to carbonate.

3. Diagenetic alteration of groundmass of many volcanic fragments mainly to gxeenish celadonite, sometimes chlorite and/or chlorophaeite (yellow mineral). Obliteration of rock fragment boundaries. Iornblende remains relatively fresh. Probable vesicular volcanic glass alters entirely to celadonite, chlorite, or chlorophaeite with spherical amygdules (vesicles) infilled with radiating chlorite or celadonite.

4. Formation of authigenic celadonite matris from alteration of volcanjc clasts infilling pore space, reduction of porosity. Rare carbonate infills some pores.

5. Oxidation of iron mineral (magnetite/ilmenite) to leucoxene and less comonly to hematite, precipitation in pore spaces as cement (not very abundant).

\section{CLASSIFICATION (ailbert, 195\%):}

Lithic arenites include sarnples: $\mathrm{RRR}-376 \mathrm{~A}, 376 \mathrm{~B}, 383,384$, and 404. (volcanic) and 397

Arkosic wackes include samples: RRR-395 and 401 Lithic wackes include samples: RRR-378, 379, 382A, 382B (volcanic)
and 393

In general, most of the coarse-grained sandstones are arenites ( $<10 \%$ matrix) and axe composed predominantly of volcanic lithic fragments al though some are composed of almost equal amounts of fine-grained sedimentary, rolcanic, and plutonic rock fragments. The arkosic wackes are composed of predominantily plagioclase feldspar and lesser or equal amounts of quartz. Many of the rackes ( $>10 \%$ matrix) may be wackes due to diagenesis rather than original matrix and the original sediment was an arenite $(<10 \%$ matrix). 
PETROGRA FHIC REPORT

UNTON OIJ, COMPANY

North Slope Samples.

Sample No. RRRm 376A

Analyst: A. R. Hiem

Rock Name: hematite cemented volcanic granule conglomerate

Number of points counted: 653

Date: August 15, 1972

Slide Quality: fair, only part of section is covered

TEXTURE

Frameworik:

Porosity: 2.7\%; Type: granulax, spaces in the clasts

Median grain size: granules

Sorting: poor

Shape and rounding: subangular to angular; rectangular shaped clasts; some spherical grains
Textural Maturity (Folk): Mature: 1. No matrix
2. Poor sorting
3. Subangular fragments

Preferxed orientation: Iong axes of rock fragments parallel to long direction of thin section

\section{MTNERALOGY}

Framework minerals:

Quartz: 5.1\%; Types: 1. Large elongate subangular mosaic or polycrystalline quartz clasts; the quartz in the clasts contain sutured or microstylolitic contacts and has strained extinction (4.4\%)

2. trace of angular coarse sand size strained quartz $(0.7 \%)$

Feldspar: trace; Type: a few plagioclase laths associated with volcanic rock fragments.

\section{Rock fragments:}

Chert: $7.7 \%$; elongate to triangular shaped fragments of cryptocrystalline quartz; a variety of kinds and sizes: a) some with patches and micro veinlets of mosaic quartz (1.2\%)

b) many have hematite filled fractures cutting them

c) some are fibrous chalcedony varieties;

d) some with specks of magnetite altered to hematite and thin micaceous clay fllaments oriented parallel to long direction of chert clasts 
Sample No. RRR-376A continued...

Rock fragments: continued ...

Volcanic: 41.9\%; 1. Porphyritic lava flow clasts; large euhedral Carlsbad twinned plagiociase and reddish brown crystals of unknown composition in a groundmass composed of cryptocrystalline quartz (zeolites?) and celadonte; a few clastg contain euhedral feldspars in opaque clayey groundmass;

2. Many clasts contain irregular hematite-filled fractures; in some clasts feldspar laths badly altered to celadonite or zeolites? (one green clast consists of green celadonite replaced microlites of feldapar).

8.5\%; Celadonite replaced rock fragments; probably originally volcanic, before alteration: some are elongate celadonite replaced elasts; looks like replacenent of vesicular volcaric glass (spherical celadomite-filled amygdules and shards?).

Mudstone: 7.5\%; Mudstone or shale clasts with angular silt-sized quartz and mainly opaque clay matrix; some contain contorted laminations; some clasts are cut by micro-veins of mosajc quartz

\section{Compositional Maturity (Folk): Immature: many lithic fragments}

Diagenetic Alteration: 1. Volcanic and other rock fragments altered to celadonite or brownish clay mineral.

2. Some feldspar in volcanic clasts replaced by celadonite and clear zeolites?.

3. Partial replacement of some grains by hematite.

4. Large rock clasts completely altered to brownish clay.

Matrix: ( $<.03 \mathrm{~mm})$ none

Cement: $26.3 \%$; nonse as quartz overgrowths

Type: hematite cement, abundant dark opaque material between clasts; also fills veinlets and fractures in the clasts; the abundance of dark hematite gives the dark reddish hue to the rock; the greenish hue is due to the abundance of celadonite replaced rock fragments. Veinlets of mosaic quartz cut clasts and hematite cement (quartz veinlets are post-hematite cement). 
Sample No. RRR-376A continued...

SUMMARY

INEERENCES AND CONCLUSTONS

\section{Provenance:}

Rock Types: I. Volcanic lava flows and volcanic glass shards, basic and/or intermediate composition; can't tell which.

2. Chert = sedimentary source from nodules in limestone erosion of deep-water novaculite beds or devitrified acidic volcanic glass.

3. Mosaic quartz $=$ probably vein quartz associated with sedimentary and volcanic source rocks (it is also contained within sedimentaxy and rolcanic clasts).

4. Mudstone or shale = some ray be penecontemporaneous rip-ups of mud bottom (too soft to be transported far) or derived from erosion of fine-grained sedimentary rock; quarti veinlets in some sedimentary clasts suggest erosion from lithified sedimentary rocks.

Relief and Climate: mechanical weathering predominated over chemical weathering at times as in such climates as arctic(?) or temperate (seasonal variation - winterg); steep topography hills, mountains, high stream gradients; steep relief a rapid erosion and removal of unstable rock fragnents before chemical decomposition.

Depositional Enviroment and Transport Mechanism:

High energy current transport accounts for coarse grain size, orientation of clasts, and winnowing of fines, such curxent transport as in streams (fluvial) or offshore littoral marine currents; poor sorting and general subangularity suggest rapid deposition and burial before any extensive reworking and abrasion (not likely surî) as in deltaic or river channel, or near sea cliffs or mouth of large river entering sea. Deposited in an area of high subsidence and sedimentation rates (as in geosynclinal sequence).

\section{Diagenetic History:}

1. Diagenetic alteration of rolcanic clasts and rock clasts of unknown original composition to celadonite, brownish clay and iron oxides; and alteration of some feldspar to celadonite and/or zeolites(?).

2. Oxidation and precipitation of abundant hematite cement by groundwater in the interstices and pores between rock clasts = lithification accompanied by compaction and fracturing of clasts; precipitation of iron oxides in fractures in rock fragments.

3. Later compaction and more fracturing and precipitation of vein quartz in rock clasts and hematite cenent.

Porosity too low (pores infilled with hematite cement) to be a potential reservoir. 
PETROGRAPHTC REPORT

UNION OIL COMPANY

North Slope Samples

Sample No. RRR-376B

Analyst: A. R. Niem

Rock Name: Very coarse-grained volcanj.c arenite

Number of points counted: 613

Date: August: 12, 1972

Slide Quality: good, except one side gouged out

TEXTURE

Framework:

Porosity: 1.6\%; Type: intergrain

Median grain size: very coarse sand, Range: medium sand to granvie Sorting: fair

Shape and rounding: rounded to subrounded; equidimensional and spherical. rock fragments

Textural Maturlty (Folk): Mature to supermature

1. Little matrix (authigenic)

2. Well-sorted to fairly sorted

3. Rounding high

Preferred orientation: none

\section{MTNERAJOGY}

Framework minerals:

Quartz: $2.7 \% ; .1$. Angular quartz $(0.5 \%)$

2. Vein quartz associated wi.th some chert as microveins and in large plutonic lithic fragment; straight contacts $(0.4 \%)$

3. Mosaic quartz, straight contacts and sutured varieties with strained extinctions (1.8\%)

Feldspar: 4.7\%; Types: Plagioclase albite twinned = abundant;

Untwinned feldspar (orthoclase?) = trace;

Andesine crystals in volcanic fragments;

01igoclase crystals in plutonic fragments (range: $\mathrm{An}_{12} \mathrm{Ab}_{88}$ to $\mathrm{Ab}_{32} \mathrm{An}_{68}$ ).

Micas: 1.7\%; Types: chlorite filling anygdules in rolcanic rock fragments, as alteration product

2. Chlorophaeite as alteration of groundmass in volcanic rock fragments

Amphiboles: $0.9 \%$; Hornblende as euhedral crystals, some as phenocrysts in volcanic rock fragments; others as individual crystals 
Pyroxene: 1.4\%; Colorless to yellow clinopyroxene (augite?); large semirounded grains, some as phenocrysts in volcanic rock fragments

Heavy minerals: $0.8 \%$; Rectangular nasses of leucorene; some metallic ilmenite al tered to loucorene

\section{Rock fragnents:}

Chert: 5.5\%; Mainly cryptocrystaljine quartz with some contorted filaments of iron oxide passing through clast; some with feldspar phenocrysts; some with authigenic replacement of chert by yellowish-orange chlorophaeite; some rounded chert clasts contain spherulites of chalcedony with extinction crosses form pattern.

Volcanic: 61.5\%; very fine- and coarse-grained clasts.

Types: 1. Clasts with pilotaxitic (or trachytic) texture = feldspar microlites aligned in subparallel manner with accessary magnetite (now leucorene) in groundmass of yellowish chlorophaeite (alteration mineral);

2. Some porphyritic lava clasts with phenocrysts of feldspar or clinopyroxene.

3. Some volcanic clasts with intersertal texture, random orientation of feldspar laths and/or hormblende with secondary minexals chlorite, chlorophaejte, or dark clay.

4. Intergranulax texture ox intergrowth of feldspar laths and clinopyroxene (augite?).

5. Some volcanic clasts with spherical amygdules filled with radiating needles of chlorite.

Sedimentary: 4.4\%; mostly siltstone as large semi-round fragnents composed of abundant angulax siltosized quartz grains in a clay matrix.

Rare mudstone, dark black opaque siliceous? clast with silt-sized quartz and abundant orange-brown clays (some with dark fibrous laminae); one mastone clast consisting of angular clay fragments cemented with rein quartz (straight contacts) and clay

Plutonic: 4.7\%; Acidic plutonic or intrusive rock fragments; crystalline intergrowth of coarse crystalg of strained quarti, plagioc]ase feldspar (oligoclase), untrinned feldspar (orthoclase?) or hornblende and plagioclase.

Compositional Maturity (Folk): Irmature: many rock fragments; some wellrounded clasts

Diagenetic Alteration: 1. Feldspar altered to scattered patches of sericite, chlorite, and chlorophaeite.

2. Chlorophaeite and chlorite replacing groundmass of rolcanic rock fragments. fragments.

3. Grayish clay masses replaced up to $3 / 4$ of rock 
Sample No. RRR-376B continued...

Matrix: ( $<.03 \mathrm{~mm}$ ) 9.2\%; in part authigenic chlorophaeite (some indistinct volcanic rock boundaries)

Type: dark opaque clay that outlines grain boundaries as thin line; probably prinary

Cement: trace; none as overgrowths.

Type: some leucoxene cement

\section{SUMMARY}

INFERENCES AND CONCLUSTONS

\section{Provenance:}

Rock types: I. Mainly volcanic; hornblende and/or pyroxene andesite lava flow $=$ source for pilotaritic fragments, hornblende, intergertal volcanic rock fragments, andesine, and plagioclase feldspar; clinopyroxene phenocrysts in volcanic rock fragnents may have some basaltic rock composition for source rock.

2. Chert; some have phenocrysts and micro quartz veins, may be devitrified or altered acidic rolcanic glass; chert terrain source of mosaic quartz (as vein quartz);

3. Chlorite/chjorophaeite altered volcanic glass $=$ glassy lava rock fragments;

4. Minor source $=$ acid intrusive rock, granodiorite and quartz diorite source for quartz and plagioclase; a few with hornblende; also source for plagioclase feldspar and untwinned fieldspar (orthoclase);

5. Minor source = fine-grained sedinentary source siltstone, mudstone (may be penecontemporaneous ripups of mud bottom), shale; chert - nodules in limestone or sedimentary chert beds.

Relief and Climate: Steep relief (hills, mountains) and mechanical. weathering prevalent over chemical at times (e.g. temperate climate) resulted in rapid erosion and transport of rock fragnents before complete chemical destruction.

Depositional Environnent and Transport Mechanism:

Texturally mature to supermature implies that there was some winnowing of fines, reworking and some sorting of clasts and rounding of rock fragments, not necessarily a surf zone or beach environment; could be also fluvial or nearshore shallow marine enviroment as rock fragments will. round very rapidly with minimurn of transport in any high energy environment compared to quartz.

Diagenetic History:

1. Compaction minor.

2. Reduction of porosity by formation of diagenetic minerals, chlorite, chlorophaeite, and clays in pores.

3. Oxidation and hydration of ilmenite/magnetite in rock fragments and individual clasts to leucoxene.

4. Authigenic growth of chlorophaeite and some chlorite in the groundmass of volcanic rock rragments. 
PETROGRAPHTC REPORT

UNION OII COMPANY

North Slope Samples

Sample No. RRR-378

Analyst: A. R. Niem

Rock Name: fine-grained arkosic-rolcanic wacke

Number of points counted: 626

Date: August 24, 1972

Slide Quality: good, thin on one side but most of section covered

TEXTURE

Framework:

Porosity: 5.7\%; Type: intergranular

Median grain size: fine sand

Sorting: fair to good

Shape and rounding: angular clasts are prisms, elongate in shape

Textural Maturity (Folk): Immature to mature:

1. Abundant matrix

2. Faix to good sorting

3. Angular grains

Preferred orientation: none

MINERALOGY

Framework minerals:

Quartz: 3.9\%; Types: angular elongate fragments mostly with strained extinction (3.3\%)

mosaic quartz and/or zeolites(?); clasts containing amygdules filled with greenish celadonite $(0.6 \%)$

Feldspar: 26.8\%; Types: mostly untwinned feldspar occurring as angular prisms; some cavities in feldspars filled with greenish celadonite; also albite twinned.

plagioclase occurs as angular euhedral Amphiboles: 1.2\%; green hornblende prisms

Pyroxene: 5.5\%; colorless to pale yellow clinopyroxene prisms Heavy minerals: $2.0 \%$; Types: 1 . magnetite/ilmenite as square opaque and spherical grains:

2. glauconite(?) occurs as dark green rounded spherical and elongate pellets; some contain quartz and other minerals in their interiors

3. Ieucoxene occurs as alteration product on some clasts and as part of matrix 
Sample No. RRR-378 continued...

Carbonate: $6.7 \%$; single crystals of carbonate completely replace feldspar prismatic clasts or occurs as pore fillings

\section{Rock fragments:}

Chert: $0.7 \%$; cryptocrystaliine quartz, some with scattered crystals of opaque iron oxides

Volcanic: $5.7 \%$; altered volcanic lava flow fragments consisting of a few feldspar microlites in greenish celacionite groundmass; one rock fragment with hornblende phenocryst; possibly sickle-shaped shards altered to clay;

Altered volcanic? clasts: $17.2 \%$ greenish fibrous celadonite and/or chlorite replaces roundish to elongate clasts, many containing amygdules filled with radiating celadonite or chlorite = devitrified volcanic glass (punice?); some celadonite replaced clasts contain plagioclase laths = volcanic

Mudstone: 1.5\%; brownish mudstone or shale clast, rounded; larger in size than quartz and feldspar clasts; consists of dominantly brownish clays and opaque iron oxides with some silt-sized angular quartz; one mudstone clast with micro quartz vein

Compositional Maturity (Folk): Imnature: abundant unstable feldspar and pyrowene and volcanic rock fragnents

Diagenetic Alteration:

1. Individual carbonate crystals completely replace feldspar prisms

2. Untwimned feldspar and plagioclase altered to patches of sericite and/or carbonate

3. Amygduloidal celadonite and/or chlorite replaced volcanic glass(?) clasts (pumice?)

4. Rare carbonate replacement of celadonite replaced clast

5. Carbonate crystals infill pores

6. On one edge of section, the matrix has been oxidized to limonite/ hematite (weathering)

Matrix: (<.03 $\mathrm{mm}) \quad 22.3 \%$; Original and some authigenic

Types: clay matrix = celadonite and brownish to opaque cryptocrystalline aggregates surrounding and between framework clasts some part of the celadonite matrix may have formed by the breakdown of rock fragments although there are few volcanic rock clasts without definite boundaries and totally there are few rock fragments in the sample. 
Sample No. RRR-378 continued ...

SUMARY

INFERENCES AND CONCLUSTONS

\section{Provenance:}

Rock types: 1. Major source $=$ volcanic source as evidenced by the occurrence of:

a) volcanic flow fragments, also could be source for plagioclase feldspar, pyroxene, and hornblende

b) celadonite/chlorite replaced volcanic glass.(?) containing chlorite infilled amygdules (vesicles) or bubble walls; probably originally punice clast - pumiceous tuff source or may be primary ash fall material intermixed with terrestrial detritus

2. Minor source = fine-grained sedimentary rock; mudstone, shale, one clast with micro quartz vein; some may be penecontemporaneous current ripeups derived from the nuxd bottom.

3. Source of quartz and untwimned feldspar = igneous or metamorphic; too angular to be recycled sedimentary source.

Relief and Climate: Mechanical weathering dominates over chemical at times (as during winter in a temperate climate) to produce rock fragments and abundant chemically unstable feldspar and pyroxene of a fine grain size; but chemical weathering prevailed at times to produce some clay (matrix) from unstable minerals. Rapid erosion over terrain of moderate to subdued relief resulted in fine grain size and abundant original clay and unstable mi neral grains.

Depositional Environment and Transport Mechanism:

Deposition in a relatively low energy environment in which elay settied with fine-grained detritus (although some clay was diagenetically formed). Iittle or no reworking by currents as suggested by the general angularity of the framework grains and abundance of matrix although some sorting occurred in transport. Fine grain size suggests transport was by low energy currents. Angularity of clasts suggest non-eolian. Environment of deposition a lagoonal overbank, swamp, or offshore marine sands below wave base, i.e. deep-water neritic not surf. Occurrence of possible glauconite pellets suggests deposition in marine environment although more likely these pellets are really celadonite derived fron alteration of acidic volcanic glass as there are many other such celadonite replaced fragments in the section.

\section{Diagenetic History:}

1. Compaction; some feldspar prisms penetrate and compress the celadonite replaced clasts.

2. Authigenic alteration of volcanic glass with vesicles to celadonite and sometimes to chlorite; infilling of vesicles with radial spherulites of celadonite/chlorite.

3. Precipitation of carbonate crystals in pores from $\mathrm{Ca}$ and carbonate. rich groundwater solutions and replacement of some feldspar by large crystals of carbonate (probably calcite).

4. Alteration of twinned and untwinned feldspar to patches of sericite and/or carbonate. 
PETROGRAPATC REPORT

UNTON OTL CORPANY

North Slope Samples

Sample No. RRR-379

Analyst: A. R. Niem

Rock Name: Very fine-grained arkosic wacke Date: August 22, 1972

Number of points counted: 650

Slide Quality: okay, too thin on one side; artificial crack across section

\section{TEXTURE}

Framework:

Porosity: 3.8\%; Type: intergramulax

Median grain size: very fine-grained sand

Sorting: good to fair

Shape and rounding: angular; laths and elongate minerals

Textural Maturity (Folk): Immature: 1. Abundant matrix; authigenic in port

2. Fair sorting

3. Very angular clasts and minerals

Preferred orientation: fine laminations parallel to long direction of slide

\section{MINERALOGY}

Framework minerals:

Quartz: 9.2\%; Types: angular elongate strained and unstrained grains $(8.4 \%)$ and mosaic quartz $(0.8 \%)$

Feldspar: $38.7 \%$ Types: clay altered feldspar plagioclase as laths and prisms; albite twinned; some completely replaced by micaceous clay sericite

untwinned feldspar (orthoclase?) and

Micas: 4.6\%; Types: chlorite and celadonite replaced elongate mineral clasts

Pyroxene: 1.2\%; Type: colorless, angular, high relief Heavy minerals: $5.6 \%$; Types: ilmenite/magnetite (2.3\%) as irregular rectangular grains with edges altered to hematite or leucoxene (3.3\%) zircon, colorless (trace) 
Sample No. RRR-379 continued . -

Rock fragments:

Chert: $0.9 \%$

Volcanic: $0.7 \%$

as angular equidimensional cryptocrystalline clasts parallel alignment of microlites of plagioclase feldspar; grain boundaries destroyed by diagenesis suggests a rolcanic origin

Compositional Maturity (Folk): Immature: abundant feldspar laths and some volcanic rock fragments

Diagenetic alteration: 1. Some untwimned feldspar altered to sericite patches.

2. Some plagioclase completely altered to clay

Matrix: (<.03 $\mathrm{mm}) \quad 34.9 \%$ in part original; in part authigenic

Types: Mixture of greenish and brownish clay (celadonite) matrix with some opaque iron oxides (levcoxene) that may be acting as a cement

SURMARY

INFERENCES AND CONCLUSIONS

\section{Provenance:}

Rock types: 1. Volcanic flows source for altered volcanic rock fragments, plagioclase feldspar, and pyroxene

2. Quartz $=$ acidic igneous rocks or metanorphics; too angular to be recycled from sedimentary rocks

3. Rare chert $=$ sedinentary chert beds, chert nodules in limestone, or devitrified volcanic glass

Relief and Climate: moderate relief; at times, extensive chemical weathering of rock sources produced original clay (original matrix) and breakdown of rock fragments and minerals into very fine sizes. The occurrence of a few rolcanic rock fragments and abundant unstable feldspar suggests some moderate relief in a temperate climate with moderate erosion and burial rates.

Depositional Enviroment and Transport Mechanism:

Fine grain size, angularity, and possibly some original matrix suggest deposition in very low energy enviroment with little or no reworking by currents such as overbank deposits in delta (lagoonal, swamp) or floodplain deposits or offshore marine - perhaps below wave base in deep-water. Fine grain size and laminations suggest deposition by low energy current (i.e. Low flow regime)

Diagenetic History: 1. Extensive alteration of some plagioclase feldspar to clay and some untwinned feldspar altered to patches of sericite.

2. Formation of authigenic clay matrix by breakdown of rolcanic rock fragments and other unstable minerals. 
PETROGRAPHIC REPORT

UNTON OII, COMPANY

North SIope Samples.

Sample No. RRR-382A

Analyst: A. R. Niem

Rock Name: very fine-grained arkosic wacke Date: August 24, 1972

Number of points counted: 614

Slide Quality: fajr; only thin partial section

TEXTURE

Framework:

Porosity: 4.5\%; Type: granular

Median grain size: very fine sand

Sorting: good

Shape and rounding: angular, equidimensional to lath-like

Textural Maturity (Folk): Irmature: 1. Abundant matrix

2. Sorting good to fair

3. Very angular grains

Preferred orientation: none

\section{MINERALOGY}

Framework ninerals:

Quartz: 3.5\%; Types: angular, clear, normal or non-undulatory extinction types most abundant

Feldspar: 39.7\%; Types: plagioclase (andesine) albite twinned, prismatic, elongate angular laths untwinned feldspar (orthoclase or untwinned plagioclase); altered to patches of sericite

Amphiboles: 2.4\%; fresh, unaltered pleochroic greenish prisms of hornblende

Pyroxene: $1.6 \%$; colorless clinopyroxene

Heavy minerals: $9.6 \%$; leucoxene; trace of colorless euhedral zircon

Rock fragments:

Volcanic: $1.9 \%$ altered volcanic rock fragnents; aggregates of microlites of plagioclase feldspar in green celadonite groundmass; rock boundaries hard to discern from matrix; one rock fragment contains hornblende and plagioclase phenocrysts 
Sample No. PRR-382A continued ...

Rock fragments: continued...

Celadonite replaced clasts: $8.6 \%$ mostly greenish;. some yellowish chlorophaeite replaced clasts; altered clay (and carbonate?) replaced clasts of unknown composition

Mudstone: $0.3 \%$; trace of rudstone clasts

Compositional Maturity (Folk): Irmature: abundant unstable feldspar

Diagenetic Alteration:

1. Clay matrix alteration of some feldspar boundaries produced serrated edges.

2. Feldspar altered to abundant patches of sericite and celadonite.

3. Groundmass of volcanic rock fragnents altered to greenish celadonite; also entire clasts altered to celadonite or chlorophaeite.

Matrix: (<.03 mm) 27.5\%; in part original(?) but some authigenic from breakdown of volcanic rock fragments

Types: brownish-yellow clay as aggregates between clasts and replaced clasts also: some greenish celadonite

Cement: trace; none as overgrowths

Type: leucoxene outlines some framework grain boundaries as opaque iron oxides and also occurs as irregular opaque patches between clasts

SUMMARY

TNFERENCES AND CONCLUSTONS

Provenance:

Rock types: 1. Mainly intermediate volcanic lava flows (probably hornblence andesites and some basalts); source for andesine plagioclase feldspar, hornblende, minor pyroxene and a]tered rolcanic rock fragments which have hornblende and plagioclase phenocrysts.

2. Mudstone $=$ fine-grained sedimentary source.

3. Quartz and untwinned feldspar (orthoclase or untwinned plagioclase = igneous and metamorphic source

Relief and Climate: Moderate relief, rapid erosion to preserve unstable feldspar and hornblende; however, extensive weathering in temperate climate did produce original clays (part of matrix) and breakdown of minerals and rock fragments into very fine grain size.

Depositional Environment and Transport Mechanism:

Fine grain size, angularity, and clay matrix suggest deposition in low energy envixonment by weak currents with little or no reworking and fairly rapid burial; such an environment as floodplain, swamp, lagoonal, offshore littoral away from surf zone, neritic, or abyssal deeps below wave base. 
Sample No. RRR-382A continued...

Diagenetic Hi story:

1. Authigenic breakdown of groundmass of volcanic rock fragments to green celadonite; destruction of rock boundaries and formation of some authigenic matrix.

2. Other unidentifiable mineral clasts completely altered to clay and some carbonate(?).

3. Feldspar, moderate to extensive alteration to patches of sericite, particularly along cleavage and twin planes. Some matrix replaced feldspar grain boundaries to produce serrated edges.

4. Hornblende, fresh and relatively unaltered; resisted diagenetic chemical attack. 
PETROGRAPHTC REPORT

UNION OIJ COMPANY

North Slope Samples

Sample No. RRR-382B

Analyst: A. R. Niem

Rock Name: coarse-grained rolcanic wacke

Date: August 1, 1972

Number of points counted: 612

Slide Quality: okay; partial section; plucking of hornblende to create artificial porosity

TEXTURE

\section{Framework:}

Porosity: 1.7\%; Type: intergrain and plucking of hornblende (artificial)

Median grain size: coarse

Sorting: poor

Shape and rounding: most rock fragments angular and spherical; feldspar prismatic euhedral and angular; a few anomalous very well-rounded lithic fragments

Textural Maturity (Folk): Immature: 1. Abundant clay matrix

2. Poor sorting

3. Angular grains

Preferred orientation: none

\section{MINERALOGY}

Framework minerals:

Quartz: trace

Feldspar: 27.2\%; Types: plagioclase (22.5\%) (oligoclase - andesine) albite and some pericline twinning; some zoned plagioclase; untwinned feldspars $(4.7 \%)$ (potash feldspar?) with incipient alteration in spots to sericite

Micas: 6.8\%; Types: biotite (trace); celadonite replaced clasts Amphiboles: 9.3\%; hornblende crystals, also occurs as phenocrysts in rolcanic clasts

Heavy minerals: trace magnetite with edges altered to hematite

Rock fragments:

Chert: $0.1 \%$ 
Sample No. RRR-382B continued...

Rock fragments: continued ...

Volcanic: 38.0\%; Types: internediate composition (hornblende andesite) occurs as large clasts containing phenocrysts of untwinned feldspar and hornblende in groundmass of plagioclase microlites and green celadonite; some rolcanic (basalt?) fragments with plagioclase phenocrysts in celadonite or isotropic brown clay groundmass; rare quartz or zeolite filled amygduloidal volcanic clasts

Compositional Maturity (Folk); Immature: alnost entixely composed of unstable volcanic fragments, hormblende, and feldspax

Diagenetic alteration: 1. Plagioclage feldspar altered to seattered particles of sericite and celadonite.

2. Celadonite and minor carbonate partly replaces feldspars (mainly along twin planes).

3. Celadonite extensively replaced glass and other minerals in groundrass and phenocrysts of volcanic rock fragments.

Matrix: ( $<.03 \mathrm{~mm})$ 16.5\%; original matrix

Types: opaque to dark green clay (concentration of celadonite) outlines many of the lithic and mineral clasts (grain boundaries are distinct, not likely diagenetically altered matrix).

Cement: none as overgrowths

Type: trace - leucoxene in dark clay matrix acting as a cement?

SUMMARY

INFERENCES AND CONCLUSIONS

\section{Provenance:}

Rock types: almost entirely volcanic source

1. Intermediate hornblende andesite and basalt(?) flows = volcanic fragments, hornblende, feldspar, andesine, magnetite;

2. Minor source (trace of biotite, untwinned potash feldspar(?), quartz) $=$ acid plutonic or low-grade metamorphic

Relief and Climate: Steep: mountainous, cliffs, hills result in rapid removal, transport, and burial of lithic fragments before much chemical weathering; mechanical weathering in a cool temperate climate predominated over chemical breakdown producing abundant chemically unstable lithic and mineral grains. 
Sample No. RRR-382B continued...

Depositional Environment and Transport Mechanism:

Current transport of coarse-grained lithics and rapid deposition and burial before much sorting or winnowing of fines could occur. Iittle or no reworking suggested by abundance of clay, poor sorting, angularity of. grains, and euhedral shapes of crystals of feldspar and hormblende. Such a sediment is produced in deltaic and fluvial channels and/or deep-water turbidite environments.

\section{Diagenetic History:}

1. Compaction minor; no evidence of extreme compaction such as pressure solution.

2. Light and dark green celadonite replaced groundmass (glass?) of many volcanic rock fragments; replacement along twin planes of plagioclase, replacement of untwinned feldspar and rarely hornblende crystals; may form some matrix.

3. Minor carbonate replacement of feldspar and oxidation of some iron minerals to leucoxene and/or hematite. 
PETROGRAPHIC REPORT

UNION OTI COMPANY

North Slope Samples

Sample No. RRR-383

Analyst: A. R. Niem

Rock Name: very coarse-grained volcanic arenite

Number of points counted: 637

Date: August 15, 1972

Slide Quality: good; one edge thin or missing

\section{TEXTURE}

Framework:

Porosity: 3.1\%; Type: granular

Median grain size: very coarse sand

Sorting: poor

Shape and rounding: Some soft sedimentary and rolcanic rock fragments are well-rounded and spherical in shape; mostly quartz, feldspar, and other rock fragments that are euhedral, angular to subangular and prismatic.

Textural Maturity (Folk): Mature: I. No matrix

2. Poor sorting

3. Most grains angular

Preferred orientation: none

\section{MINERALOGY}

Framework minerals:

Quartz: 10.1\%; Types: 1. Mosaic quartz with straight contacts and non-undulatory or normal extinction; may be oriented vein quartz or quartzite (some with chlorite flakes) (4.6\%);

2. Angular clear quartz (5.5\%)

Feldspar: 5.4\%; Types: 1. Plagioclase, albite twinned, euhedral and prismatic altered to sericite and a clay with high relief;

2. Trace of microcline in a plutonic clast

3. Some untwinned feldspar, orthoclase? or perthite

Micas: 5.1\%; Types: chlorite/celadonite/chlorophaeite

Amphiboles: $1.2 \%$ hornblende

Pyroxene: $8.1 \%$; augite? as large yellowish clasts altered partly to clay; some occur in abundance with microlites of feldspar or with hornblende in volcanic rock fragments 
Sample No. RRR-383 continued...

Heavy minerals: $1.2 \%$ magnetite

Clay replacing feldsparg: $2.1 \%$

\section{Rock Iragments:}

Chert: 2.8\%; cryptocrystal]ine quaxtz; some contain phenocrysts of feldspar sevitrified rolcanic glass

Volcanic: 31.1\%; 1. Feldspar microlites of many sizes in different volcanic clasts:

2. Some with pilotaxitic texture of laths of plagioclase with groundnass of greenish celadonite ox dark brownish opaque clay and iron oxides;

3. Poxphyritic texture; euhedral plagioclase phenocrysts floating in groundmass of feldspar microlites or celadonite;

4. Intersertal texture; randomly oriented microlites of plagioclase and magnetite with celadonite/ chlorite/clay groundmass;

5. Fibrous green yellowish celadonjte or chlorophaeite replaced clasts $(5.1 \%)$; may have been volcanic glass;

6. Amygduloidal clasts filled with fibrous radiating celadonite;

7. Hornblende intergrown with pyroxene in one clast Siltgtone and mudstone: 12.2\%; dark black or brownish laminated and massive shale or mudstone fragments; some are well-rounded; some clasts contain spherical mosaic quartz floating in clay matrix; may be recrystallized radiolaria

Plutonic: . 10.9\%; acid intrusive (granodiorite or quartz dionite) rock clasts; interlocking crystalline quartz and plagioclase (albite and pericline twinned) and occasional hornblende; micro crystals of apatite, mica, magnetite, rutile needles, and zircon in feldspar crystals; some untwinned feldspar (potash?) intergrown with quartz in granular interlocking crystalline texture; feldspar occurs as euhedral grains; quart\% as anhedral grains; some chlorite alteration minerals intergrown between quartz and feldspar in the plutonic clasts.

Compositional Maturity (Folk): Immature: many rock fragments and unstable minerals

Diagenetic Alteration:

1. Much of plagioclase feldspar in the plutonic clasts is altered to scattered patches of sericite and dark brownish clay.

2. Groundmass in volcanic clasts altered to brownish to opaque clay or celadonite. Some entire clasts replaced by celadonite. 
Sample No. RRR-383 continued ...

Matrix: $\quad(<.03 \mathrm{~mm}) \quad 9.5 \%$ probably authigenic

Type: minor amounts of greenish celadonite and minor.chlorite between framework clasts, outlining their boundaries; some opaque clay and iron oxides (leucoxene) outline clast boundaries

Cement: trace; less than 1\% as overgxowths on a few quartz grains

Type: celadonite acts as cement(?)

SUMMARY

INFERENCES AND CONCLUSTONS

Provenance:

Rock types: 1. Mostiy rolcanic flows probably intermediate (andesite) suggested by occurrence of pilotaxitic texture and. hormblende in some; oligoclase to andesine plagioclase; some nay be basalt volcanic rock fragments;

2. Abundant fine-grained sedimentary rock; mostly laminated mudstone and shale; some with radiolaria suggest deep-water shales; trace of siltstone; may be penecontemporaneous rip-ups of mud bottom;

3. Chert may be sedimentary; chert nodules out of Iinestone bed or deep-water cherts; some are definitely devitrified rolcanic acidic glass (chert with euhedral feldspar phenocrysts)

4. Abundant acidic intrusive (granodiorite or quartz diorite) $=$ quartz, plagioclase (oligoclase to albite), hornblende, and trace of microcline and orthoclase.

Relief and Climate: Hechanical weathering dominated over chemical weathering to produce abundant lithics (e.g. temperate with winter season or arctic(?)); steep topography in source area (hills, cliffs) resulted in rapid removal of unstable lithics before chemical decomposition could occur; steep stream gradient transported unstable material rapidly.

Depositional Environment and Transport Mechanism:

Coarse grain size suggests deposition by high energy current (too coarse to be eolian); poor sorting, general angularity of most clasts suggests rapid deposition and burial with little or no reworking (not surf) as in rapidly subsiding geosyncline with high rates of sedimentation; could be fluvial channel, deltaic channel, or offshore littoral or near sea cliffs.

\section{Diagenetic History:}

1. Alteration of groundmass of volcanic clasts to celadonite, greenish micaceous clay, chlorite, or brownish to opaque clay. Volcanic clasts altered to celadonite or cryptocrystalline quartz (chert).

2. Authigenic formation of celadonite clay matrix; filled and reduced pore spaces. Some framework grain boundaries indistinct due to alteration. 
PETROGRAPHIC REPORT

UNION OIL COMPANY

North Slope Samples

Sample No. RRR-384

Analyst: A. R. Niem

Rock Name: coarse-grained volcanic arenite Date: August 17, 1972

Number of points counted: 723

Slide Quality: good, covers entire section

TEXTURE

Framework:

Porosity: 1.6\%; 10w-unlikely reservoir; Type: granular

Median grain size: coarse sand; Range: medium to very coarse sand

Sorting: fair

Shape and rounding: spherical, subrounded to rounded rock fragments, but minerals (quartz and feldspar) are angular to subangular

Textural Maturity (Folk): Mature: 1. Iittle matrix

2. Fair sorting

3. Rounded to subrounded to angular clasts

Preferred orientation: slight suggestion of elongate axes of grains parallel to long direction of thin section

\section{MINERALOGY}

Framework minerals:

Quartz: 13.1\%; Types: mosaic quartz with sutured edges and strained extinction $(6.2 \%)$

quartz mostly with strained or undulatory extinction, probably vein quartz (6.9\%); one large oriented polycrystalline or mosaic quartz may be quartzite; some micrographic quartz varieties in plutonic fragments

Feldspar: 12.7\%; Types: 1. Plagioclase, prismatic, euhedral, albite twinned, some pericline twinning, oscillatory zoning.

2. Untwinned feldspars (orthoclase?) in plutonic fragments and euhedral grains, partly altered to sericite

3. Trace of microcline in one plutonic fragment 
Sample No. RRR-384 continued...

Amphiboles: 1.9\%; hornblende as pleochroic green prismatic grains

Pyroxene: $3.8 \%$ clinopyroxene yellowish to colorless; some associated with quartz in plutonic fragments and in rolcanic clasts

Heavy minerals: $1.9 \%$; hematite; trace of magnetite/ilmenite

Celadonite replaced clasts: $3.8 \%$ chlorophaeite/celadonite/chlorite replaced clasts, hornblende, pyroxene, and groundmass of volcanic rock fragments

\section{Rock fragments:}

Chert: 2.0\%; equidimensional cryptocrystalline quartz; some with euhedral plagioclase phenocrysts $=$ devitrified acidic volcanic glass

Volcanic: $40.6 \%$; 1 . Some with pilotaxitic texture; mostly plagioclase microlites; some with intergrown microlites of plagioclase and hornblende in an iron oxide groundmass.

2. Many with intersertal and pilotaxitic texture (most abundant type of clast).

3. Some amygduloidal volcanic clasts; amygdules filled radially with celadonite or chlorite

4. Clasts of porphyritic plagjoclase feldspar in an iron oxide and clay or microcrystalline quartz groundmass

Siltstone: trace; aligned chlorite flakes and abundant angular silt-sized quartz

Mudstone: 6.6\%; abundant mudstone or shale, silt-sized angular quartz or euhedraj prisms of plagioclase in fine brown clay matrix with contorted dark iron oxide or carbonaceous stringers; some dark carbonaceous varieties; some contain micro quartz veins

Plutonic: $8.4 \%$ acid plutonic fragments = clasts of crystalline intergrowth of quartz, plagioclase, and feldspar with trace of microcline, orthoclase(?)

Compositional Maturity (Folk): Immature: abundant rock fragments

Diagenetic alteration: sericite.

Plagioclase altered to brownish-orange clay? and scattered patches of

Matrix: (<.03 mm) 3.0\%; authigenic; not all rock fragments have distinct boundaries; some matrix may be original

Type: celadonite (greenish clay matrix) occurs outlining framework grains and infilling pockets between framework grains.

Cement: minor amount as quartz overgrowths

Type: 1. Main cement = trace of thin irregular filaments of leucoxene and other opaque iron oxides between clasts and occurs in fractures in clasts

2. Trace of minor cement carbonate occurs in small patches 
Sample No. RRR-384 continued...

SUMMARY

INFERENCES AND CONCLUSTONS

Provenance:

Rock types: 1. Mainly volcanic flows s source for porphyritic, anygduloidal, and intersertal fragnents.

2. Mainly hornblende andesite and pyroxene basalts, or dacites, and other intermediate volcanic flow rocks - source for pilotaxitic texture, for andesine oligoclase, plagioclase feldspar, and hornblende; basalt source for intersertal textured clasts?

3. Acjd plutonic intrusives = source for granodiorite or quartz diorite fragments; source for coarse hornblende, quartz, oligoclase feldspar, trace of microcline and pyroxene?

4. Fine-grained sedimentary rocks = mainly mudstone and shale, some siltstone; may be rip-up of mud bottom although many clasts with micro quartz veinlets suggest erosion from a lithified source.

5. Mosaic quartz probably vein quartz, clear and milky varieties may be associated with sedimentary rock source area as micro quartz veins that occur in mudstone clasts; no obvious metamorphic varietjes.

6. Chert $=$ sedimentary chert bed or in Iimestone nodules or devitrified acidic volcanic glass (especially those containing euhedral feldspar phenocrysts)

Relief and Climate: Abundant unstable lithic and mineral grains suggest mechanical weathering dominated over chemical (in a cool temperate climate). Rapid exosion over steep topography (hills and mountains in source area) and rapid transport to site of deposition before much chenical decomposition. Source area near depositional. basin (?).

Depositional Environment and Transport Mechanism:

High energy current transport of coarse debris, winnowing of fine clay; some sorting and rounding of soft volcanic clasts but rapid deposition and burial before any major reworking by currents (e.g. surf) as in fluvial. channels, deltaje channels, offshore littoral near sea cliffs as suggested by mostly angular and poorly sorted large mineral grains: Deposition in rapidly subsiding basin (geosyncline) with hjgh rates of sedimentation.

\section{Diagenetic History:}

1. Minor compaction.

2. Alteration of some clasts to celadonite, chlorite, and chlorophaeite.

3. Groundmass of many rolcanic rock fragments altered to opaque leucoxene, brownish clay or celadonite, chlorophaeite. Infilling of amygdules in rock fragnents with celadonite.

4. Scattered alteration of plagioclase to sericite patches.

5. Formation of authigenjc matrix of celadonite, trace of carbonate, and opaque iron oxides (leucoxene) cement destroys porosity unlikely reservoir. 
Sample No. RRR 393

Analyst: A. R. Niem

Rock Name: medium-grained lithic (volcanic) wacke

Number of points counted: 784

Date: August 1, 1972

Slide Quality: good; hornblende plucked in places

\section{TEXTURE}

Framework:

Porosity: 4.2\%; Type: intergranular in matrix and granular; porosity result of diagenetic alteration (solution of grains) and probable thin section plucking (artificial)

Median grajn size: medium sand; Range: very fine to mediun sand

Sorting: fair

Shape and rounding: Angular and euhedral prisms of feldspar and hornblende; angular spherical to pyramid-shaped rolcanic clasts

Textural Maturity (Folk): Immature: I. Abundant clay

2. Faix sorting

3. Very angular euhedral grains

Preferred orientation: none

\section{MINERALOGX}

Framework minerals:

Quartz: 18.2\%; Types: angular quartz (14.0\%) equidimensional; mostly strained variety; mostly straight contacts with other grains; few sutured mosaic quartz - strained and sutured contacts $(4.2 \%)$

Feldspar: 9.3\%; Types: plagioclase feldspar (albite or andesine); perthite - intergrowth of plagioclase and k-spar or quartz; few untwinned feldspar (potash?)

Amphiboles: 11.1\%; Type: hornblende with abundant sericite inclusions (0.2\%?)

Heavy minerals: $1.1 \%$; leucoxene = opaque material diffused in clayey matrix.

Unidentified mineral: 1.5\%; hornblende?, pyroxene?, olivine?, or matrix 
Sample No. RRR-393 continued ...

\section{Rock fragnents:}

Chert: $0.3 \%$

Volcanic: 14.6\%; Types: Some intermediate volcanic clasts with pilotaxitic texture (aligned microlites of feldspax); also randomly oriented

Euhedral feldspax laths (Carlsbad twinned) in celadonite clayey matrix (intersertal texture)

$11.9 \%$

Siltstone/mudstone: $4.4 \%$

Chlorite and celadonite replaces elongate

Plutonic: $0.2 \%$ granodiorite or quartz diorjte

Compositional Maturity (Folk): Immature: many unstable grains as hormblende and feldspars as well as volcanic rock fragments

Diagenetic alteration: extensive alteration

1. Many plagioclase and untwinned feldspars contain scattered patches of sericite.

2. Groundmass of volcanic clasts altered to celadonite and opaque dark clay; many fragments hard to recognize.

3. Amygdules in volcanic(?) glass(?) devitrified to fibrous celadonite and/or chlorite clasts; ghosts of anygdules left.

4. Many hornblende grains extensively altered to dark opaque clay.

Matrix: (<.03 mm) 21.6\%; orjginal and authigenic: a few ghost outlines of clasts = evidence for authigenic; most lithic grain boundaries, however, are altered to diagenetic green celadonite instead of original dark matrix clay suggests most clay matrix is or primary origin

Types: some irregular patches of dark opaque clay replaces groundmass of some volcanic clasts; between framework grains of others

Cement: $1.1 \%$; none as overgrowths

Types: very minor carbonate and greenish celadonite

SUMMARY

INFERENCES AND CONCLUSTONS

\section{Provenance:}

Rock types: I. Mostly hornblende andesite lava flows = intermediate flow rocks as source for volcanic clasts, hornblende, andesine(?), and plagioclase feldspar; some basaltic flows.

2. Fine-grained sedimentary source = siltstone, mudstone and clay matrix.

3. Trace of acid plutonic rock = granodiorite (minor source) - large quartz and plagioclase feldspar; but may be source for mosaic quartz, quartz, and some untwinned potash? feldspar. 
Sample No. RRR-393 continued ...

\section{Provenance: continued...}

Relief and Climate: Steep - hilly and mountainous terrain in source area to allow rapid removal by erosion, probably water, of ungtable rolcanic lithics and unstable minerals (feldspar. and hornblende) before chemical weathering reduced them to clay. Probably cool temperate climate for mechanical weathering to break rock into fragments and warm at times to form clay (in matrix); tropical climate would have destroyed this unstable mineralogy and produced clay only.

Depositional Enviroment and Transport Mechanism:

Rapid transport and burial (current as in fluvial and marine littoral geosynclinal; too coarse-grajned and angular to be of wind origin). Iittle or no reworking of clastic debris resulted in retention of fine clay matrix (some is authigenj.c), little abrasional rounding of framework clasts and minimal sorting. Could be deltaic chamel, fluvial channel or deep-water turbidite enviroment (if abundance of clays is mostly original). Siltstone and mudstone clasts and clay matrix may be current rip-ups of sea or river bottom muds and silts.

\section{Diagenetic History:}

1. Some compaction; some twinning of feldspars is bent, hornblendes fractured, quaxtz infills fractures.

2. Feldspars altered to scattered patches of sericite, less commonly to carbonate.

3. Groundmass of volcanic clasts altered to chlorite and celadonite resulting in formation of abundant micro feldspar laths in an altered green matrix.

4. Amygdulojdal glass (pumice?) altered to yellowish clay, chlorite, and celadonite, and infilling of amygdules with spherulitic celadonite or micromosaic quartz or zeolites.

5. Dark clay replaced some volcanic rock fragment groundmass. 
PETROGRA PHIC REPORT

UNION OII, COMPANY

North Slope Samples

Sample No. RRR-395

Analyst: A. R. Niem

Rock Name: medium-grained arkosic wacke

Date: August 26, 1972

Number of points counted: 610

Slide Quality: good, one edge thin

TEXYUURE

Framework:

Porosity: 5.0\%; Type: granular

Median grain size: fine to medium sand

Sorting: fair

Shape and rounding: angular, prisms and equidimensional grains

Textural Maturity (Folk): Immature to mature: 1. Matrix (authigenic)

2. Sorting fair

3. Angular clasts

Preferred orientation: none

\section{MINERALOGY}

Framework minerals:

Quartz: 20.3\%; Types: Polycrystalline or mosaic quartz (4.6\%), angular equidimensional fragments; most strained and microstylolitic or sutured contacts; some may be quartzite

Normal quartz (15.7\%), angular, equidimensional; some quartz grains contain abundant inclusions (pyroxene, zircons?)

Feldspar: 21.9\%; Types: plagioclase feldspar (oligoclase-andesine), albite twinned and Carlsbad twinned; euhedral; angular, some subrounded; trace of microperthite and microcline; trace of untwinned feldspar (potash feldspar?)

Micas: 0.4\%; Type: biotite as large elongate flakes Amphiboles: 4.9\%; hornblende, unaltered prisms, pleochroic green Pyroxene: 4.7\%; Clinopyroxene, colorless, small euhedral 6-sided crystals and large irregular equidimensional. grains. 
Sample No. RRR-395 continued ...

Heavy minerals: $3.2 \%$ magnetite/ilmenite as squarish to rectangular masses (generally smaller than other mineral fragments) and octahedral euhedral crystals; in part altered to leucoxene; grains are randomly scattered throughout thin section.

Rock fragments:

Chert: 1.3\%; cryptocrystalline quartz; micro quartz veins in chert clasts; some fibrous chalcedony varieties

Volcanic: 11.4\%; 1. Pilotaxitic texture = feldspar microlites aligned;

2. Intersertal texture $=$ random orientation of feldspar microlites in groundmass of brownish clay or green celadonite;

4.9\%; Mostly chlorophaeite (yellow) replaced clasts

Schist: $0.4 \%$ and celadonite/chlorite (green) replaced clasts Trace of elongate quartz-mica (biotite) schist fragment; composed of aligned (foliated) mica and minor angular quartz.

Sedimentary: 1.9\%; Mudstone (argillite) occurs as elongate fragments with contorted opaque fibers; Trace of siltstone, mostly silt-sized quartz

PIutonic: $4.9 \%$; in clay matrix. Acidic plutonic (quartz diorite or granodiorite) rock fragments; interlocking crystalline texture of coarse-grained quartz, plagioclase feldspar (and/or hornblende) form a clast.

Compositional Maturity (Folk): Immature: abundant rock and unstable mineral fragments

Diagenetic Alteration:

1. Plagioclase feldspars altered to patches of sericite, to chlorophaeite or celadonite.

2. Groundmass of volcanic rock fragments altered to celadonite or chlorophaeite; clasts altered completely.

3. Some quartz grain boundaries are irregular due to partial. replacement by clays.

Matrix: $(<.03 \mathrm{~mm})$ 14.0\%; in part diagenetic

Types: yellowish chlorophaeite or greenish celadonite matrix surrounds framework grains and in some cases merges with volcanic rock fragments (no boundaries) suggesting some diagenetic alteration. 
Sample No. RRR-395 continued...

SUNMARY

INFERENCES AND CONCLUSTONS

Provenance:

Rock types: 1. Mostly volcanic lava flows of intermediate composition (e.g. andesite) and some basalts?; source for pilotaxitic fragments, plagioclase (andesine), hornblende, and pyroxene.

2. Altered volcanic glass? = source for celadonite/ chlorophaeite replaced clasts.

3. Minor source $=$ acid intrusive (granodiorite or quartz diorite) $=$ source for plutonic clasts, plagioclase (oligoclase), hornblende, untwinned feldspar (orthoclase), quartz, and biotite.

4. Fine-grained sedimentary clasts, mostly mudstone, argillite; some siltstone; some mudstone may be penecontemporaneous ripups.

5. Minor low-grade metamorphic source; quartz mica schist = source for mosaic quartz (may be quartzite), schist fragment, quartz, and biotite.

6. Chert $=$ sedinentary chert beds or devitrified acidic volcanic glass.

7. Mosaic quartz could be vein quartz; some micro veins of quartz cut chert grains = chert source area or some may be quartzite.

Relief and Climate: Steep relief (hills, mountains, sea cliffs); rapid erosion; mechanical weathering dominant at times (cool temperate climate) so that many unstable rock and mineral fragments produced and broken down to medium sizes.

Depositional Environment and Transport Mechanism:

Since provenances were varied (igneous, metamorphic and sedimentary), there must have been extensive mixing of various rock types during transport although volcanic is dominant. Fine to medium grain size suggests low to moderate energy transport. Fair sorting, angularity, and preservation of unstable "soft" mudstone and schist rock fragments suggest rapid deposition and burial in depositional environment with little or no reworking (e.g. fluvial, delta, offshore littoral). In such enviroments there are high rates of sedimentation and subsidence hence burial as in' a geosyncline.

\section{Diagenetic History:}

1. Feldspar altered to patches of sericite.

2. Groundmass of volcanic clasts altered to celadonite and chlorite or chlorophaeite; obliteration of some rock fragment boundaries and formation of authigenic matrix. 
PETROGRAPHIC REPORT

UNION OIL COMPANY

North Slope Samples

Sample No. RRR-397

Rock Name: medium-grained lithic arenite

Number of points counted: 620

Slide Quality: good

\section{TEXTURE}

Framework:

Porosity: $0.6 \%$; low, unlikely reservoir

Median grain size: medium sand; Range: very fine to coarse sand

Sorting: poor

Shape and rounding: feldspars = prismatic; quartz $=$ angulax and sutured contacts; volcanic fragments = equidimensional, angular edges

Textural Maturjty (Folk):

Immature to mature: 1. Fines winnowed

2. Poorly sorted

3. Angular grains (except some large soft volcanics which round easily)

Preferred orientation: appears to be two finer-grained layers parallel to long direction of slide

\section{MINERALOGY}

Framework minerals:

Quartz: 28.3\%; Types: Quartz (23.3\%) some with many inclusions of long slender crystals of chlorite or hornblende and zircon;

Mosaic quartz $(5.0 \%)$ with strained and sutured or microstylolitic contacts; some altered to carbonate and iron oxides

Feldspar: 14.6\%; Types: Plagioclase (andesinemoligoclase) euhedral with inclusions of zircon, albite twinned, some pericline twinning, and oscillatory zoning (typical of volcanic plagioclase).

Micas: 1.6\%; Types: muscovite, chlorite, yellowish clay Amphiboles: 12.9\%; hornblende

Pyroxene: $4.5 \%$; augite(?)

Heavy minerals: 1.9\%; Types: leucoxene; antigorite(?)

Others: light yellow micaceous clay, chlorophaeite (7.9\%), completely replaces whole anhedral minerals = replaces bubble shard or amygdule in one case 
Rock fragments:

Chert: $2.0 \%$

Volcanic: 16.1\%; Types: intermediate volcanics; pilotaxitic and poikolitic intergrowth of feldspar laths and and opaque iron oxides; some with microamygdules; some with olivine or pyroxene phenocrysts and feldspar in clay groundmass

Siltstone: $3.8 \%$ olivine basalt?

Plutonic: 1.2\%; in one clast microcline intergrown with quartz egranodiorite; hornblende intexgrown with quartz $=$ granodiorite

Compositional Maturity (Folk):

Immature: many volcanic lithics and unstable hornblende

Diagenetic alteration: 1. Anhedral crystals of carbonate replace sections of volcanic fragments.

2. Volcanic flow fragments partly replaced by chlorite.

3. Small anhedral hornblende may be replacement product in some volcanic fragments.

Matrix: not significant amount

Cement: $4.0 \%$; none as quartz overgrowths

Types: some chlorite, leucoxene, and carbonate act as a minor cement

SUMMARY

INFERENCES AND CONCLUSTONS

\section{Provenance:}

Rock types: 1. Volcanic flow (if olivine or pyroxene) = basalt; some pilotaxitic texture = probably intermediate flow; andesites - hornblende.

2. Acid intrusive (granodiorite) = quartz, microcline, oligoclase, orthoclase, hornblende; particularly for the quartz with inclusions

3. Fine-grained sedimentary $=$ large siltstone clasts

Relief and Climate: very steep relief (hills, mountains); predominantly mechanical weathering (as in temperate climate) producing abundant angular rock and mineral fragments which were rapidly removed down steep relief (mountainous and hilly country) by erosional processes before much chemical weathering.

Depositional Environment and Transport Mechanism:

High energy transport mechanism removed medium-grained material and mixed various sources together; fine clays winnowed out but deposition and burial rapid (as sorting and rounding very low; no reworking (not surf); poor sorting and angularity indicate probable enviroments fluvial, deltaic streams, offshore littoral in rapidly subsiding area with high rates of sedimentation. 
Sample No. RRR-397 continued ...

Diagenetic History:

1. Compaction produced tightly packed lithic sandstone a destroyed porosity.

2. Minor pressure solution of quartz produced some sutured or microstylolitic contacts.

3. Alteration of unknown minerals or glass (bubble seen in one) to chlorite and yellowish fibrous micaceous clay (chlorophaeite).

4. Partial alteration of feldspar to sericite, carbonate (some entirely replaced), and chlorite.

5. Alteration of volcanic lithic groundmass to chlorite, other clays and matrix of magnetite to leucoxene.

6. Oxidation of magnetite/ilmenite to leucoxene.

7. Alteration and compaction processes destroyed porosity - unlikely reservoir. 
PETROGRAPHIC REPORT

UNION OII COMPANY

North Slope Samples

Sample No. RRR-401

Analyst: A. R: Niem

Rock Name: altered fine-grained arkosic wacke

Number of points counted: 690

Date: July 29, 1972

Slide Quality: good

TEXTUREE

Framework:

Porosity: trace; Type: intergrain

Median grain gize: fine sand; Range: very fine to fine sand

Sorting: good (excluding matrix)

Shape and rounding: angular quartz and feldspar; mainly equidimensional clasts; some elongate in shape.

Textural Maturity (Folk): immature to submature: 1. Abundant matrix 2. Good sorting 3. Low rounding

Preferred Orientation: yes, light and dark laminations parallel to long direction of section

\section{MINERAIOGY}

Framework minerals:

Quartz: 21.4\%; Types: angular pieces (20.0\%) with irregular edges corroded by matrix; minor amounts of strained mosajc quartz (1.4\%); some radiating chalcedony varieties;

Feldspar: 18.8\%; Types: mostIy plagioclase and untwinned prisms; most of which are altered to sericite; trace of microcline

Micas: trace; Types: 1. Celadonite = alteration product as stringers throughout matrix;

2. Chlorite occurs as occasional patches

Pyroxene: $1.8 \%$ colorless

Heavy minerals: 7.2\%; Types: opaque iron oxides, mainly leucoxene; trace of magnetite/ilmenite partly altered to leucoxene; colorless zircon - euhedral and irregular shape 
Sample No. RRR-LO1 continued...

\section{Rock fragments:}

Chert: $1.4 \%$ clear cryptocrystalline quartz

Volcanic: 8.6\%; many intermediate and/or basic volcanic (perhaps basalt fragment containing feldspar laths) and sone pilotaxitic texture (andesites?)

Mudstone: $2.7 \%$ semi-rounded dark to opaque claymich clasts

Compositional Maturity (Folk): Immature: many rolcanic rock fragments and compositionally unstable feldspars

Diagenetic alteration: many altered volcanic rock fragments faintly recognizable by abundance of bundles of feldspar microlites; most fragments are extensively altexed to greenish celadonite, chlorite, and other clay minerals; plagioclase feldspar altered to sericite or more rarely to carbonate.

Matrix: ( $\leqslant .03 \mathrm{~mm}) \quad 32.6 \%$ authigenic

Types: many volcanic rock fragments and feldspar boundaries are indistinct and merge with clayey matrix consisting of either micaceous clay, cryptocrystalline quartz or zeolites, celadonite, and/or splotches of leucorene; grains almost not in grain support suggests an authigenic matrix.

Cement: $6.0 \%$; no cement as orergrowths

Types: isolated crystals of carbonate scattered in matrix; celadonite clay may be acting in part as cement; two veinlets cut across thin section; one of mostly carbonate replacing quartz, the other of quartz with minor carbonate crystals.

SUMMARY

INEERENCES AND CONCLUSTONS

\section{Provenance:}

Rock types: 1. Volcanic flows, intermediate or andesite (as suggested by pilotaxitic texture) and/or basaltic -. could be source of feldspar also.

2. Mudstone $=$ sedimentary lithic fragment; or penecontemporaneous rip-up.

3. Microcline $=$ acid igneous or metamorphic

Relief and Climate: steep to moderate, rapid removal of broken up rock fragments; temperate climate (winters) mechanical weathering processes important for reducing source rock to rock fragments and feldspars before chemical weathering could reduce all the particles and unstable feldspars to clays. They were rapidly removed by erosional processes due to steep relief. 
Sample No. RRR-LOI continued...

Depositional Environment and Transport Mechanism:

Low energy current transport (low flow regime) suggested by laminae (unless cross-bedded). Concentration of dark iron minerals differentiates. dark laminae from light laminae. Rapid deposition with little reworking as suggested by low rounding in quartz and feldspar and presence of soft unstable volcanic rock fragments, not high energy surf or eolian

envixonment. If some of the matrix is original, it would suggest deposition in a low energy environment such as a turbidite or fluvial. or deltaic overbank, estuarine, or lagoonal.

Diagenetic History:

1. Alteration of volcanic rock fragments groundmass to celadonite, chlorite, and other colorless clay minerals.

2. Oxidation and hydration of ilmenite/magnetite to leucoxene.

3. Partial alteration of feldspar to sericite.

4. Infiling of microfractures with quartz which then was replaced by carbonate and infilling of few pores with carbonate cenent by groundwater after lithification.

Porosity is too low due to diagenetic alteration and cementation for this rock to be a good potential reservoir. 


\section{PETROGRA PHIC REPORT \\ UNTON OIL COMPANY \\ North Slope Samples}

Sample No. RRR-402

Analyst: A. R. Niem

Rock Name: medium-grained subfeldspathic lithic arenite

Number of points counted: 605

Date: August 16, 1972

Slide Quality: faix; rock section covers only $\frac{1}{2}$ of slide

TEXTURE

Framework:

Porosity: 2.1\%; Type: granular

Median grain size: medium sand

Sorting: poor

Shape and rounding: angular to subangular elongate clasts

Textural Maturity (Folk): Mature: 1. Minor matrix (authigenic arid original)

2. Poor sorting

3. Angular to subangular grains

Preferred orientation: elongate grains approximately parallel to long direction of thin section.

\section{MTNERALOGY}

Framework minerals:

Quartz: 18.1\%; Types: 1. Polycrystalline or mosaic quartz in variety of sizes, consist of elongate subangular strained and sutured polycrystalline quartz $(11.5 \%)$;

2. Angular clear quartz, many with nonundulatory or normal extinction $(6.6 \%)$

Feldspar: 3.4\%; Types: plagioclase; acid andesine $\left(\mathrm{An}_{30} \mathrm{Ab} 70\right)$, albite twinned, prismatic euhearal grains

Micas: trace; Types: biotite flakes; muscovite

Amphiboles: $0.9 \%$; Hornblende occurs as individual green pleochroic prismatic crystals or as rounded clasts composed of many hornblende crystals

Pyroxene: 6.6\%; Clinopyroxene as large colorless anhedral crystals Heavy minerals: 4.7\%; Trace of magnetite; leucoxene (iron oxide) replaced clasts 


\section{Rock fragments:}

Chert: 23.4\%; Chert forms largest clasts; composed of cryptocrystalline quartz; some clasts with fractures of dark opaque clay, one very large clast has spherical vugs (recrystallized radiolaria?) filled with either green celadonite, mosajc quartz, or carbonate; micro-veinlets of vein quartz with straight contacts and normal extinction cut through many chert clasts.

Volcanic: 10.9\%; 1. Pilotaxitic texture microlites of ffeldspar in a celadonite groundnass
2. Intersertal texture $=$ random orientation of feldsparg in green celadonite or opaque iron oxide matrix

5.4\%; Fibrous green celadonite/chlorite/chlorophaeite replaced clasts; some have radiating spherical cavities filled with celadonite.

Schist: 0.8\%; quarta raica schist clast

Quartzite: $0.8 \%$; mainly clasts of strained and sutured or microstylolitic polyerystalline or mosaic quartz containing some oriented (foliated) muscovite and occasional garnet

Mudstone and siltstone: 1.6.3\%;

1. Mostly mudstone or shale or argillite (slate), sone with aggregate polarization; occurg as dark brown and some laminated elongate clasts $(4.8 \%)$ with clay and dark iron oxide stroingers; some clasts are cut by micromosaic quartz veins;

2. Trace of siltstone, mostly abundant silt-sized angular quartz, feldspar, and muscovite in clay matrix.

Compositional Maturity (Folk): Immature: abundant rock fragments and unstable minerals

Diagenetic Alteration: 1. Groundmass in volcaric rock fragments altered to celadonite; entire mineral or rock clasts altered to greenish celadonite;

2. Authigenic matrix; celadonite infills pores.

3. Plagioclase feldspar altered to patches of sericite.

\section{Matrix: ( $<.03 \mathrm{~mm}) \quad 9.5 \%$}

Types: Authigenic = celadonite (greenish fibrous clay) and chlorophaeite between framework clasts (may be acting as a cement); bourdaries of volcanic clasts not distinct, merges with celadonite matrix.

Original = dark black opaque carbonaceous clay or iron oxides occur as filaments and contorted laminae; outlines distinct grain boundaries

Cement: trace; none as overgrowths

Type: leucoxene as thin yellow-orange filanents around framework clasts 
Sample No. RRR-LO2 continued...

SUMMAPY

INFERENCES AND CONCLUSTONS

\section{Provenance:}

Rock types: 1. Mainly chert sedimentary chert beds in deep-water eugeosynclinal; may contain recrystallized radiolaria suggesting deep-water chert;

2. Fine-grained sedimentary rocks, mostiy carbonaceous mudstone (organic-rich?), shale, argillite; some laminated, many not rip-up because micro quartz veins cut through each clast suggesting they were lithified; some may be bottom ripups; some siltstone source.

3. Hosaic quartz = many micro quartz reins consisting of mosaic quartz cut individual rock fragments (chert, mudstone, volcanics); probably source for much mosaic quartz; some may be metamorphic quartitite;

4. Trace of some low-grade metamorphic = quartz mica schist, metamorphic quartzite; quartzite up to gaxnet grade metamorphic; source for quartz;

5. (Third most abundant) intermediate volcanic andesite flows source for andesine plagioclase and pilotaxitic volcanic rock fragments; also source for hornblende and clinopyroxene phenocrysts; may be some basalt.

6. Trace of biotite and muscovite $=$ low-grade metamorphic or acid plutonic source.

Relief and Clinate: In'source area, steep relief (nountains, sea sea cliffs?, hilis) and mechanical weathering predominant at times over chemical weathering; cool temperate or arctic(?) climate = results in rapid removal and transport of unstable rock and mineral detritus before extensive chemical decomposition.

\section{Depositional Environment and Transport Mechanism:}

Coarse grain size, poor sorting, and angularity suggest high energy current transport (not eolian) and rapid deposition and burial in rapidly subsiding basin (e.g. geosyncline with high rates of sedimentation). No major reworking by currents (such as surf) is suggested because of angularity and poor sorting although clays may have been winnowed. Probable environment $=$ fluvial channel, deltaic channels, offshore littoral or nearshore littoral near a rugged coastline (sea cliffs).

\section{Diagenetic history:}

1. Some compaction; quartz fragments penetrate mudstone rock fragments; some mudstone rock fragments contorted around resistant grains reduced porosity.

2. Alteration of groundmass of volcanic clasts to celadonite; some whole mineral clasts (volcanic glass?) and pyroxene altered to celadonite or chlorophaeite.

3. Authigenic clay precipitated (celadonite) as matrix infills pores = low porosity; unlikely reservoir. 
PETROGRAPHTC REPORT

UNION OIL COMPANY

North Slope Samples

Sample No. RRR-LOL

Analyst: A. R. Niem

Rock Name: Volcanic-lithic granule conglomerate

Number of points counted: 618

Date: August 14, 1972

Slide Quality: poor; plucked and pitted = artificial porosity

TEXTURE

Framework:

Porosity: 2.8\%; Type: artificial due to plucking, irregular grinding and pulling rock section apart

Median grain size: granules

Sorting: poor

Shape and rounding: subangular to rounded; triangular to rectangular grains

Textural Maturity (Folk): Mature: 1. Ifttle matrix

2. Poor sorting

3. Grains subrounded to rounded

Preferred orientation: none

\section{MTNERALOGY}

Framework minerals:

Quartz: 2.4\%; Types: a) subangular to subrounded equidimensional; clear; mostly contains normal extinction

b) mosaic quartz minor, occurs as pore filling between framework grains

Feldspan: 1.2\%; Types: Occurs as slender nicrolites of prismatic shape mostly in volcanic and plutonic clasts albite or Carlsbad twinned plagioclase feldspar (oligoclase to albite $\mathrm{Ab}_{9} \mathrm{An}_{8}$ ) untrimed feldspar (orthoclase?) altered to sericite; contains a cleavage

Micas: trace; chlorite/celadonite in natrix and alteration product of groundmass in rolcanic clasts 
Sample No. RRR-LOL continued...

Rock fragments:

Chert: 9.3\%; cryptocrystalline quartz, some with phenocrysts of euhedral plagioclase suggesting devitrified acidic volcanic glass origin; most chert contains micro quartz vejns and patches of mosajc quartz

Volcanic: 54.)\%; (the feldspar microlites are a variety of sizes from silt to coarse sand due to different degrees of crystallization before eruption)

a) Some clasts contain pilotaxitic texture; Iong slender feldspar laths in subparallel orientation;

b) Porphyritic (oligoclase-andesine) lava flow clasts consist of euhedral plagioclase laths with a groundmass of microlites of plagioclase and iron oxides (magnetite?), some have a groundmass of celadonite or opaque clays:

c) Clasts with intersertal texture consist of plagioclase microlites (Carlsbad twinned) in random Quartzite: $2.7 \%$ orientation in a celadonite altered groundmass

Muảstone: $15.5 \%$; rounded grains of mudstone or shale; mostly dark black, bromish or opaque clay size matrix with some silt size grains of angular quartz or mica

Plutonic: 6.3\%; large rounded clasts with a granular texture of interlocking untrinned (potash?) feldspar, plagioclase, and quarta crystals acidic intrusive, granodiorite; some contain anhedral crystals altered to chlorite and chlorophaeite and opaque leucorene-limonite

Compositional Maturity (Folk): Irmature: abundant rock fragments

Diagenetic alteration: 1. Groundmass of volcanic fragments altered to celadonite/chlorite

2. Feldspar altered to patches of sericite

3. Some clay replaced clasts

Matrix: (<.03 mm) 4.0\%; mostly original (most grains have distinct boundarjes) and partly authigenic

Type: Fine-grained clay intermixed with celadonite with some silt-sized angular quartz

Cement: $1.2 \%$; none as quartz overgrowths

Type: hematite/leucoxene cement as fine filaments and aggregates outline some grain boundaries 
Provenance:

Rock types: 1. Mainly volcanic clasts and chert; pilotaxitic texture in some clasts suggests intermediate volcanic source such 2s andesite flows; some porphyritic volcanic clasts contain plagioclase oligoclase suggesting some clasts may be from dacitic flows or others may be from basaltic flows.

2. Chert from sedimentary chert beds or chert nodules in limestone; those chert clasts with plagioclase phenocrysts suggest they are derived from devitrification of volcanic glass.

3. Fire-grained sedimentary rock; mostly mudstone or shale (penecontemporaneous ripmups of the mud bottom) and some siltstone.

4. Minor source - acio plutonic (intrusive) = granodiorite (albite plagioclase (ks spar) and quarta) or quarta diorite; also source for quartz.

5. Hinor - possible metamorphic source as suggested by one quartzite fragment.

Relief and climate: Steep relief in source area. Rapid mechanical breakdown over chemical disintegration (temperate climate) produced many rock fragments which were carried away by rapid erosion (as in streams with steep gradients) before significant chemical destruction.

Depositional. Environment and Transport Hechanism:

Coarse grain size, occurrence of relatively soft sedimentary clasts, poor sorting, occurrence of matrix (if some original and not all authigenic) suggest rapid deposition and buriai, e.g. high energy current such as river. (fluvial), high anergy delta channel, or offshore littoral. High degree of rounding of softer lithic volcanic and sedimentary clasts may have been produced during minimal transport. Rounded chert may be recycled.

\section{Diagenetic History:}

1. Alteration of groundmass of volcanic rock fragments to green celadonite, chlorite, and opaque clays.

2. Alteration of feldspar to sericite.

3. Oxidation and precipitation of iron oxides (Ieucoxene and hematite) around framework grains destroys porosity.

4. Precipitation of some mosaic quartz filling pores. 
Thin sections included in Group III: RRR-266, 387, 389, 399, and 403

Age and field relationships (Rosé): Upper Cretaceous; Waring Mountains, deposjted in an east-rest basin south of the Brooks Range; source area is a metanorphic terrajn exposed to the north in the Baird. and Schwatka Mountains of the Brooks Range

\section{TEXTURE AND CLASSIFICATION:}

Two samples are fine-grained sandstones (RRR-266, 387), two are medium-graired sandstones (RRR-389, 399), and one is a coarse-grained sandstone (RRR-403). In general, these upper Cretaceous rocks are arenites (three quartz arenites, one subfeldspathic lithic arenite, and one subfeldspathic lithic wacke). That is, they lack matrix ( $55.9 \%)$ and are cemented with hematite, leucoxene, carbonate, and very minor quartz overgrowths. Only sample RRR-387 is a wacke and contajins abundant celadonite (greenish clay) matrix (16.3\%) which is probably diagenetic in origin (indistinct grain boundaries of schist and argillite fragments merge with celadonite matrix). Thus, in general, these samples are submature to mature in Folk's textural classification, with the exception of RRR-387 which is immature.

In general, the samples are poorly to moderately sorted except RRR-266 which is well-sorted. The mineral and rock clasts in all samples are angular to subangular. The mica and quartite fragments are elongate in shape and the quartz clasts elongate to equidimensional.

Unlike the lower Cretaceous rocks of similar grain sizes from the Waring basin, these upper Cretaceous rocks are more texturally mature; that is, they contain less matrix. They are also, from this limited sampling, finer grained. They are texturally similar in that they are poorly sorted and contain abundant angular grains. There is a preferred orientation of mica and schist fragments in samples RRR-399 and 403 and a lamination due to grain size differences in RRR-387.

The porosity of this upper Cretaceous suite is quite high (range: $2.5 \%$ to $28.8 \%$; average: $10.5 \%$ ) compared to the lower Cretaceous "dirty" volcanic sandstones of the Waring basin which have undergone more apparent diagenetic alteration. The porosity is mostly intergranulax; some porosity may have been artificially created in preparation of the thin section. If the porosity is naturally this high (should have some permeability tests run on samples), these rocks are potential petroleum reservoirs. At least, they have a much better potential than the lower Cretaceous rocks of the Waring basin. Precipitation of hematite and rare carbonate cement and compaction (as evidenced by contorted mica and schist fragments) has reduced porosity somewhat. 


\section{MINERAIOGY:}

The upper Cretaceous sandstones are characterized by a. distinct mineralogy from the lower Cretaceous sandstones of the Waring basin and this mineralogy can be used to recognize these sandstones.

1. These sandstones are quartz-rich clastics ( $40 \%$ to $52.5 \%$; average: $4.8 .8 \%$ ). The lower Cretaceous sandstones, on the other hand, have a much lower quartz content (range: $0.9 \%$ to $33.7 \%$; average 18.0\%). Most of the quartz is a strained or undulatory quartz variety. Some normal. or non-undulatory quartz occurs, and rare quarto clasts contain rutile needle inclusions. Some quartz grains have serrated or microstylolitic boundaries due to pressure solution interpenetration with other quartz grains. Polycrystalline or mosaic quartz (range: $1.2 \%$ to $32.0 \%$; average: 11.5\%) is composed of interlocking crystals of strained quartz that have sutured or serrated boundaries. Unlike the lower Cretaceous rocks of the Waring basin, plagioclase feldspar and untwinned feldspars are rare in these upper Cretaceous rocks. Similarly muscovite is abundant in these rocks (< $1 \%$ to $13.7 \%$; average: $6.7 \%$ ) although it is absent in the lover Cretaceous rocks. There are also traces of biotite and chlorite. Also no hornblende or pyroxene occurs in this upper Cretaceous suite. Heary minexals (trace to $<1.2 \%$ ) include leucoxene, hematite, green tourmaline, rutile needles, and zircon.

\section{Rock fragments:}

1. Chert content is 1ow. The amount of chert ranges from a trace to $8.3 \%$; averages $4.3 \%$.

2. Unlike the lower Cretaceous rocks of the Waring basin, there are abundant low-grade metamorphic rock fragments (green schist facies?) in these rocks.

a. Quartz mica schist fragments Range: trace to $13.2 \%$; average: $4.8 \%$

b. Quartzite - some micaceous quartzite Range: 0 to $16.3 \%$; average: $5.1 \%$

3. The lower Cretaceous rocks of the Waring basin contain abundant volcanic rock fragments; the upper Cretaceous rocks contain none.

4. The fine-grained sedimentary rock fragments in the upper Cretaceous rocks are mostly siltstone (range: $0.5 \%$ to $7.4 \%$; average: $3.9 \%$ ) and rare mudstone; whereas in the lower Cretaceous rocks, there is a greater abundance (up to $15.5 \%$ ) and variety of fine-grained sedimentary rock fragments; and most of these are dark mudstones. 
Cement and matrix: see texture section

PROVENANCE OR SOURCE AREA:

$$
\begin{aligned}
\text { Major = low-grade metamorphic }- & \text { quartz muscovite schist, } \\
& \text { quartz chlorite schist, } \\
& \text { quartzite and/or gneiss }
\end{aligned}
$$

The quartz mica schist and particularly the micaceous quartzite clasts in the upper cretaceous rocks could have been derived from metamorphic rocks (micaceous quartzjtes) like RRR-239 (pre-Devonian) or FRR-252 (Devonian?) in the Schwatka Mountains as the clasts are identical in mineralogy and texture to these metamorphic rocks. Rosé suggests they could also have been derived from the metamorphic terrane in the Baird Mountains of the Brooks Range.

The abundant muscovite llakes, rare biotite, and chlorite probably also were derived from low-grade metamorphic rocks as is the abundant strained or undulatory quartz although it is possible some is from acid plutonic sources. The quartz is too angular to have been recycled from sedimentary rocks. The mosaic quartz may have been derived from vein quartz or quartzite sources. The chert fragments may have a sedimentary origin (e.g. from erosion of chert nodules in a limestone bed or deepwater recrystallized radiolarian chert bed) or may have a volcanic origin (devitrified rolcanic glass).

A minor source is fine-grained sedimentary, mainly siltstone or slate (argillite).

Thus, in the lower Cretaceous the main provenance consisted of intermediate volcanic flows ( $e . g$. hormblende andesites and basalts), some fine-grained sedinentary terrane (mainly mudstone types), acid intrusives (granodiorite), and very minor low-grade metamorphics (trace). By upper Cretaceous time, the provenance was predominantly a low-grade metamorphic source of quartz muscovite schist and gneiss and/or quartzites supplying a great abundance of quartz, muscovite, and metamorphic rock fragments. 


\section{COMPOSTT TONAL, MATURTTY:}

\section{Relief and Climate:}

This suj.te of upper Cretaceous rocks is supermature to mature in composition by Folk's classification; that is, there is a great abundance of stable clasts (quartz and chert) and smaller amounts of unstable clasts such as muscovite and schist fragments.

The abundance of quartz and chert, small amount of unstable minerals (muscovite) and metamorphic rock fragments, and fine grain size suggest that the clastic material was derived from a terrane of moderate relief, low hills, relatively shallow stream gradients in a warm humid temperate climate. In such an envixonment, most rock fragments will be broken down to mineral components, and unstable minerals will be altered by chemical weathering processes to clay and winnowed away, leaving a residuum enriched in quartz and chert. Mechanical weathering processes dominate at times (in winter) to produce unstable metamorphic and sedimentary rock clasts and muscovite. This material from nearby sources?s on a moderate relief, was carried away from the site of weathering by erosional processes (streams) before complete chemical breakdown. Thus, compared with the volcanic Iithic-rich lower Cretaceous sandstones, the upper Cretaceous sandstones appear to have been derived from source areas with less rugged topography and a more temperate (warmer and more humid) climate. The increase in quartz content may also reflect derivation from a more quartz-rich terrane in upper Cretaceous time rather than a difference in climate or topography. 
Deposition in a low to moderate energy erviromment is indicated by the general mature texture and by the abundance of ruscovite flakes in this suite. The fine clays were, in general, winnowed out by current action; but deposition was fajrly rapid with little or no reworking (abrasion) as the grains are quite angular and sorting is, in general, fair to poor and there is an abundance of "soft" mica and schist clasts. A possible enviromment is fluvial, offshore marine (littoral sand bars or neritic below wave base), or deltaic channel and overbank. The orientation of mica and schist fragments in RRR-399 and RRR-403 suggest compaction and/or water current transport (currents had competence to move fine to coarse sand size detritus).

\section{DTAGENETIC HISTORY:}

1. Moderate to extensive compaction indicated by crushed and contorted large muscovite flakes between quartz grains and some interpenetration of quartz by pressure solution to produce serrated or microstylolitic boundaries between adjacent quartz grains.

2. Minor quartz overgrowths were produced on some quartz grains by precipitation of quartz by silica enriched groundwater (may have occurred during pressure solution interpenetration).

3. Oxidation of iron minerals (magnetite?) to hematite and/or remobilization and precipitation of iron oxides (hematite, leucoxene) by groundwater to form partial pore fjlling cement thereby reducing porosity.

4. $\mathrm{CO}_{2}$ and $\mathrm{Ca}^{++}$enriched groundwater precipitated carbonate (probably caIcite) in pores only in RRR-266. Some solution of quartz grain edges and replacement by carbonate minerals.

5. In RRR-387 and 403 partial alteration of micas and schist boundaries to celadonite and/or chlorite produced indistinct rock fragment boundaries and formed diagenetic celadonite and/or chlorite matrix. 
PETROGRA PHIC REPORT

UNION OIL COMPANY

North Slope Samples.

Sample No. RRR-266

Analyst: A. R. Niem

Rock Name: fine-grained micaceous quartz arenite

Number of points counted: 1237 Date: June 21, 1972

Slide Quality: thin edges, appear to be plucked and pulled apart creating much artificial porosity

TE XIURE

Framework:

Porosity: 28.8\%; Type: intergranular, veins, also irregular areas too large to be naturally formed

Median grain size: fine sand; Range: very fine to medium sand

Sorting: well-sorted except for a rare large clast

Shape and rounding: angular, some interpenetration of quartz grains

Textural Maturity (Folk): Moderate: little matrix (winnowed) but sorting fair to good and grains are angular.

Preferred orientation: none

\section{MINERALOGY}

Framework minerals:

Quartz: 49.4\%; Types: 1. Mosaic or polycrystalline quartz - most with sutured or microstylolitic boundaries; some with straight boundaries (1.2\%)

2. Strained quartz - some with opaque needle inclusions $(48.2 \%)$

Micas: 8.0\%; Types: muscovite, individual flakes and shreds dispersed throughout section

Heavy minerals: 1.2\%; Types: 1 . Hematite - between grains and as pore filling

2. Zircon and tourmaline (trace)

\section{Rock fragments:}

Chert: trace

Schist: $0.6 \%$; quartz mica schist

Sedimentary rock fragments: $0.5 \%$

Compositional Maturity (Folk): mature to supermature: mostly quartz but also contain abundant mica and rare schist fragments 
Sample No. RRR-266 continued ...

Matrix: (<.03 $\mathrm{mm}$ ) 5.9\%; probably original (all grain boundaries distinct not diagenetically formed matrix)

Type: colorless, thin microcrystalline clay aggregates between

framework clasts - may act as cement

Cement: 5.2\%; some quartz overgrowths (1ess than 1\%)

Types: Minor hematite as irregular reddish masses filling void spaces between framework mineral grains

Some clay matrix may be acting as a cement

Main cement $=$ carbonate (iron stained) infilling pores.

SUMMARY

INFERENCES AND CONCLUSTONS

Provenance:

Rock types: schist and much mica = low-grade metamorphic source; also source for quartz

composite (mosaic) quartz = vein quartz or quartzite

mudstone $=$ gedimentary rock

Relief and Climate: low to moderate relief $=$ slow removal of weathered detritus allowing chemical destruction of most unstable minerals except quartz and micas. Warm humid tenperate climate $=$ breakdown of unstable minerals and rock fragments; only quartz and micas renain; schist broken dow into smaller mica flakes.

Depositional Environment and Transport Mechanism:

Low energy depositional enviroment is suggested by the angularity and fine grain size of quartz and by the abundance of muscovite flakes (which remain in suspension for long periods of time), but some winnowing removed most of the clays and there was abrasional breakdown of most rock fragments

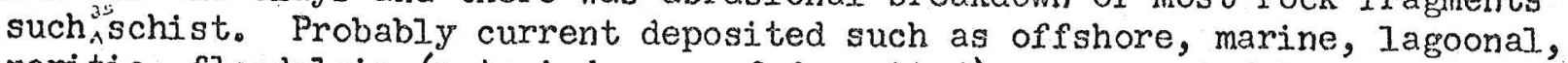
neritic, floodplain (not wind or surf deposited) as suggested by the high angularity of the grains.

Diagenetic History:

1. Compaction crushing and contortion of large mica flakes and some interpenetration by pressure solution of quartz producing serrated or microstylolitic boundaries - results in reduction of some porosity.

2. Oxidation of iron minerals to hematite; remobilization and precipitation of iron oxides by groundwater to form cement; reduction of some porosity.

3. Some recrystallization of clay minerals to form cement between grains.

4. Minor overgrowth by silica precipitation on quartz. Then carbonaterich groundwater precipitation in pores. Some solution of quartz clast boundaries by replacement by carbonate.

Good reservoir rock with high porosity. However, porosity may be artificial due to plucking of grains in the thin section. 
PETROGRA PHTC REPORT

UNTON OIL COMPANY

North Slope Samples

Sample No. RRR-387 Analyst: A. R. Niern

Rock Name: fine-grained quartz-rich subfeldspathic lithic wacke

Number of points counted: 648 Date: July 17, 1972

Slide Quality: poor; only paxtially covered; much grinding of edges

\section{TEXTURE}

Framework:

Porosity: 4.0\%; Type: intergranular

Median grain size: fine sand; Range: very fine to coarse sand

Sorting: poorly sorted

Shape and rounding: quartz - angular, elongate to equidimensional, some large grains are sub. rounded

Textural Maturity (Folk): Immature: 1. Abundant matxix

2. Poorly sorited

3. Angular grains

Preferred orientation: none; possibly a coarse layer in center parallel to long direction of section with two finer layers on either side

\section{MINERALOGY}

Framework minerals:

Quartz: 40.0\%; Types: angular strained quartz most common (33.9\%) some quartz with normal or non-undulatory extinction polycrystalline or mosaic quartz $(6.1 \%)$ with straight contacts; some chlorite or mica replaced parts of mosaic quartz

Micas: 1.5\%; Types: muscovite and chloxite (comnonly celadonite replaced) occur as aggregates and fibers

Heavy minerals: 1.0\%; Types: leucoxene, green tourmaline; scattered rutile or carborundum needles

Others: trace of celadonite/glauconite(?) as dark green irregular pellets; some may be alteration of other minerals

17.2\%; fibrous grains of celadonite/chlorite

\section{Rock fragments:}

Chert: $0.7 \%$

Schist: $13.2 \%$

Quartzite: $3.3 \%$

Siltstone/mudstone: $2.1 \%$ 
Sample No. RRR-387 continued...

Compositional Maturity (Folk): submature to mature: some lithic fragments and unstable micas

Diagenetic alteration: alteration of micas, schist, and argillite to green celadonite clay matrix forming indistinct grain boundarjes

Matrix: (<.03 mm) 16.3\%; mostly authigenic

Types: green celadonite filling the interstices between grajns; other micaceous clays associated with schist and axgijlite fragments and replace much of them; many schist and argillite grains do not have recognizable boundaries suggesting matrix formed by diagenetic alteration of framework grains.

Cement: trace; none as quartz overgrowths

Type: minor, some opaque leucoxene and iron oxides.

SUMMARY

INFERENCES AND CONCLUSTONS

\section{Provenance:}

Rock types: argillite/slate = sedimentary or penecontemporaneous mud bottom ripuups

2. chlorite, quartz mica schist, quartzite, and muscovite = low-grade metamorphic; muscovite may be acid plutonic

3. mosaic quartz = vein quartz or quartzite (metamorphic)

Relief and Climate: moderate to low relief; relatively rapid erosion and transport before complete chemical weathering of unstable mica and metamorphic rock fragments The very fine grain size and abundance of quartz suggest chemical destruction of many unstable minerals and rock f'ragments (e.g. warm, humid climate). However, mechanical weathering processes dominated over chemical weathering processes at times (e.g. winter).

Depositional Environment and Transport Mechanism:

Rapid deposition in low energy environment (such as turbidite sands introduced in deep-sea deposit or f'luvial channel) with little or no reworking as suggested by the abundance of matrix (if in part original), poor sorting, and angularity of grains = little or no abrasion. Some mudstone/argillite fragments may be current rip-ups of the mud (sea?) floor.

\section{Diagenetic History:}

1. Compaction - contortion of argillite, schist, and muscovite fragments - reduced porosity.

2. Extensive alteration of muscovite, some schist and argillite to celadonite and other micaceous clays in matrix as well as opaque leucoxene $=$ further reduction of porosity. 
PETROGRAPHIC REPORT

UNION OII COMPANY

North Slope Samples

Sample No. RRR-389

Analyst: A. R. Niem

Rock Name: pebbly medium-grained quartz arenite

Number of pojnts counted: 1215

Date: June 21, 1972

Slide Quality: good, edges too thin, plucking creates artificial porosity

TEXTURE

Framework:

Porosity: 12.4\%; Type: intragranular associated with hematite matrix

Median grain size: medium sand; Range: fine to coarse sand

Sorting: fair to poor (bimodal?)

Shape and rounding: subangular quartz

Textural Maturity (Folk): Moderately: mature: 1. Jacks matrix

2. Some sorting

3. Very angular grains, little rounding

Preferred orientation: none

\section{MTNERALOGY}

Framework minerals:

Quartz: 52.5\%; Types: mostly strained quartz (undulatory extinction), some quartz with normal or non-undulatory extinction; some interpenetration of quartz boundaries; rare guartz grains with rutile needle inclusions (39.4\%)

mosaic quartz with sutured boundaries (13.1\%)

Micas: < 1\%; Types: chlorite and muscovite occur as elongate flakes commonly contorted by compaction

Heavy minerals: trace; Types: hematite, leucoxene, trace of zircon

Clay: less than $1 \%$

Rock fragments:

Chert: $8.3 \%$

Micaceous quartzite: $3.7 \%$

Siltstone: $7.4 \%$

Compositional Maturity (Folk): supermature 
Sample No. RRR-389 continued...

Diagenetic alteration:

1. Compaction = crushed and distorted muscovite grains; reduction of porosity.

2. Some interpenetration of grains.

3. Oxidation of iron minerals (magnetite?, ilmenite) to hematite and leucoxene and groundwater precipitation of hematite cement coating grains = reduction of porosity.

Matrix: (<.03 mm) less than 1.\%; orjginal matrix

Types: dark argillaceous clay coating, with hematite in pores between grains (outlines grain boundaries); framework minerals have distinct boundaries; no minerals in slide show alteration to this clay matrix

= thus suggests original clay matrix.

Cement: $14.7 \%$; less than $2 \%$ as quartz overgrowths

Types: 1. Hematite - coats and outlines grajns as a film

2. Leucoxene - irregular shreds and fibers outline grains

3. Minor silica or quartz cement - occurs between quartz grains as overgrowths.

Cement randomly dispersed through section gives speckled appearance to slide.

\section{SUMMARY}

INEERENCES AND CONCLUSTONS

\section{Provenance:}

Rock types: 1. Micaceous quartzite = low-grade metamorphic

2. Siltstone = fine-grained sedimentary

3. Some mosaic quartz may be vein quartz

Relief and climate: low gentle to moderate relief to allow time for chemical destruction of nost unstable grains and rock fragments to clay = increase abundance of quartz. At times warm and humid (e.g. temperate) climate to produce breakdown of unstable minerals and rock fragments $=$ increase abundance of quartz.

Depositional Envi ronment and Transport Mechanism:

Winnowing of most of the fines (matrix) and some sorting of material $=$ probably fluvial or offshore littoral marine processes. Rounding too low to be eolian. Also one coarse sand clast too coarse for wind deposition.

Strong currents had competence to move pebble and mediun sand-sized material. Rounding is low which suggests no prolonged current abrasion (e.g. surf) also supported by presence of "softer" siltstone and micaceous quartzite fragments (except some larger grains well-rounded produced by prolonged current or wave abrasion = mixing of two sources?).

Diagenetic History: see diagenetic alteration

Petroleum potential: tightly packed and some cementation, however, moderate to high porosity $=$ probably a potential reservoir 
Sample No. RRR-399

Analyst: A。 R. Niem

Rock Name: rnedium-grained micaceous quartz arenite

Number of points counted: 641

Date: July 16, 1972

Slide Quality: good

\section{TEXTURE}

\section{Framework:}

Porosity:' 5.1\%; Type: intergranular (between framework grains)

Median grain size: mediun sand; Range: very fine sand to pebble

Sorting: poor

Shape and rounding: Angular grains with serrated or microstylolitic boundaries due to extensive compaction (pressure solution); grains equidimensional to elongate; mica, schist, and quartzite fragmenta elongate.

Textural Maturity (Folk): Submature: 1. Lack of fines (winnowed)

2. Poor sorting

3. Low rounding

Preferred orientation: mica and schist fragments aligned almost parallel to elongate direction of section

\section{MINERALOGY}

Framework mineralg:

Quartz: 52.2\%; Types: mostly strained quartz (46.8\%); some quartz containing tourmaline needles as inclusions and straight extinction; most have partly serrated edges; mosaic quartz ( $5.4 \%$ )

Micas: 13.7\%; Types: mainly muscovite flakes and fibers; traces of chlorite and biotite

Rock fragments:

Chert: $7.3 \%$

Schist: $2.1 \%$

Quartzite: $2.3 \%$

Siltstone: $4.2 \%$

Compositional Maturity (Folk): mature to supermature: 1. relatively abundant muscovite (unstable mineral), some schist and quartzite fragments al though quartz and chert content very high 
Sample No. RRR-399 continued...

Diagenetic alteration: contorted muscovite flakes and schist fragments (many are iron stained) altered or oxidized to hematite and probably acted as a source for the hematite cement precipitated elsewhere in the rock.

Matrix: less than $1 \%$

Cement: 12.7\%; none as quart; overgrowths

Types: heratite cement occurs as aggregates in pores between some framework grains thereby reducing porosity.

SUMMARY

INFERENCES AND CONCLUSTONS

\section{Provenance:}

Rock types: 1. Strained quartz from schist $=$ low-grade metamosphics

2. Strained quartz from quartzite $=$ low-grade metamorphics

3. Muscovite $=$ low-grade metamorphics or acidic plutonic

4. Siltstone sine-grained sedimentary

5. Chert $=$ sedimentary chert beds or nodules in limestone beds or devitrified volcanic glass

6. Mosaic quartz = possibly vein quartz or quartzite

Relief and Climate: moderate relief = relatively rapid erosion and transport before complete weathering and destruction of unstable mica and metamorphic clasts. Warm, humid temperate climate resulted in chemical destruction of most unstable mineral and rock fragments - increased abundance of quartz. However, mechanical weathering was greater than chemical weathering at times (winter) as evidenced by presence of some unstable minerals and rock fragments

Depositional Environment and Transport Mechanism:

Orientation of some mica and schist fragments due to either compaction and/or unidirectional current transport by water (medium grain size indicates fairly strong currents). Fines were winnowed, but deposition and burial. was rapid with little or no reworking (abrasion) as the grains are quite angular and sorting is only fair. Possible enviromments: fluvial or offshore marine, delta channel sands or littoral (e.g. sand bars but not surf).

\section{Diagenetic History:}

1. Extensive compaction due to burial? or tectonism? resulted in elimination of much porosity; evidence: contortion of mica grains; pressure solution of quartz and quartzite grains to produce serrated or microstylolitic boundaries.

2. Oxidation and precipitation of hematite cement in pores and as contorted stringers between framework grains - also reduced porosity.

However, porosity fair to high = potential reservoix rock. 
PETROGRA PHTC REPORT

UNION OIL COMPANY

North Slope Samples

Sample No. RRR-. 403

Analyst: A. R. Niem

Rock Name: coarse-grained subfeldspathic Iithic arenite

Number of points counted: 631

Date: JuIy 15, 1972

Slide Quality: partial section on slide; some plucked grains

\section{TEXTURE}

\section{Framework:}

Porosity: 2.5\%; Type: intergranular and plucked area on slide

Median grain size: coarse sand; Range: fine sand to pebbles

Sorting: poor

Shape and rounding: very angular to subangular quartz and quartzite fragments; some grains elongate in shape

Textural Maturity (Folk): submature: I. Angular grains

2. Lack of matrix (winnowed)

3. Poorly sorted

Preferred orientation: contorted mica and schist fragments vaguely aligned diagonally acrows slide

\section{MINERALOGY}

Framework minerals:

Quartz: 50.0\%; Types: 1. Mostly mosaic or polycrystalline quartz $(32.0 \%)$; composed of interlocking euhedral crystals with straight boundaries; some mosajc clasts contain interlocking crystals with slightly crenulated or sutured borders;

2. Straight or normal extinction clear quartz (18.0\%); some undulatory or strained quartz varieties

Feldspar: trace; Type: rare small plagioclase

Micas: 9.8\%; Types: chlorite and muscovite

Heavy minerals: trace; Types: leucoxene and hematite

\section{Rock fragments:}

Chert: $4.7 \%$

Schist: $8.5 \%$

Quartzite: $16.3 \%$

Siltstone: $5.5 \%$ 
Diagenetic alteration: development of diagenetic chlorite or celadonite matrix?

Matrix: (<.03 mm) 1.5\%; diagenetic matrix

Types: films of chlorite between framework grains formed from diagenetic alteration of chlorite schist fragments (grain borders indistinct and merge with compositionally similar matrix).

Cement: trace of quartz overgrowths (one grain)

chlorite matrix probably binding sandstone together (may act as a cement).

SUMMARY

INFERENCES AND CONCLUSIONS

\section{Provenance:}

Rock types: 1. Quartz $=$ too angular to be recycled sedimentary rocks; probably metamorphic associated with quartzite, but also may be derived from volcanic or plutonic sources.

2. Chert $=$ volcanic or sedimentary

3. Individual muscovite flakes = probably metanorphic but may be also from acidic plutonic source.

4. Muscovite and chlorite schists and quartzite or gneiss = low-grade metamorphic source

5. Siltstone and cherty mudstone = fine-grained sedimentary rocks

6. Quartzite and schist fragments = metamorphic source such as pre--Devonian micaceous quaxtzite sample RRR-239 from Schwatka Mountajns

Relief and Climate: moderate to low relief $=$ relatively slow to moderate erosion resulted in destruction of most unstable metamorphic lithic fragments, increased abundance of quartz, although source area may be close - abundant schist grains. Probably temperate climate in which chemical weathering destroyed most unstable minerals thereby increasing abundance of quartz and chert but mechanical weathering dominant over chemical at times, such as in winters to break down unstable "soft" metamorphic fragments into sand-size fragments from nearby source without complete chemical destruction of fragments.

Depositional Environment and Transport Mechanism:

Fairly coarse grain size and poor sorting $=$ rapid deposition and short transport by tractive currents (suggested by orientation of schist and mica fragments). Too coarse-grained to be eolian. Fines winnowed out. Angular and euhedral grains and abundance of "soft" mica and schist fragments suggest little or no reworking (little abrasion) and short transport such as in fluvial channels and littoral environments (offshore bars) - not surf. Diagenetic History:

1. Extensive compaction of grains as indicated by crushed and contorted appearance of schist, chlorite, and muscovite fragments = reduced porosity.

2. Formation of authigenic chlorite matrix or cement $=$ reduced porosity. 
Sample RRR-386

Field location: igneous intrusive that intrudes lower Cretaceous rocks in east-west basin (Waring Mountains?), southern Brooks Range (Rosé).

Name: porphyritic dacite or rhyodacite intrusive

\section{MINERALOGY:}

Quartz: 13.1\%: euhedral large phenocrysts containing slightly reabsorbed or embayed borders

Feldspar: 11.9\%: large euhedral phenocrysts of plagioclase (albite, acid andesine and oligoclase), also untwinned and twinned varieties

Micas: 7.4\%: chlorite infills microcracks; replaces edges of quartz and feldspar and some relict ferromagnesian phenocrysts

Heavy minerals: 5.4\%: magnetite or ilmenite occurs as small cubes and octahedrons dispersed throughout microcrystalline quartz groundmass; leucoxene occurs as irregular opaque aggregates in groundmass; hematite occurs as black opaque stringers associated with chlorite.

Groundmass: 61.3\%: interlocking microcrystalline mixture of strained quartz, feldspar microlites, and chlorite aggregates: if groundmass contains potash feldspar, the rock is a rhyodacite.

\section{EMPLACEMENT AND ORIGIN:}

Eruption of viscous acidic magma of dacitic composition as a massive flow or near surface intrusive plug or dome or less likely as a near surface rhyolite dike. Rapid cooling produced a glassy or fine-grained microcrystalline groundmass. Large phenocrysts of quartz and plagioclase feldspar formed previously in magna chamber.

\section{DIAGENETIC HISTORY:}

1. Probable devitrification and/or alteration of acidic glass groundmass to interlocking microcrystalline quartz, feldspar, and chlorite.

2. Alteration of edges of euhedral plagioclase phenocrysts to chlorite.

3. Ireegular micr-fractures formed in solidified intrusive; the resulting cracks or fractures were infilled with chlorite which in part was then oxidized to hematite.

GENERAL COMMENT: Weathering and erosion of this and other related dacite or rhyodacite intrusives could be the source for chert or fine-grained mosaic quartz (groundmass of the intrusive) for the upper Cretaceous sedimentary rocks the Waring basin as well as a source for quartz, acid plagioclase, and magnetite. 
PETROGRA PHIC REPORT

UNION OIL COMPANY

North Slope Samples

Sample No. RRR-386

Analyst: A. R: Niem

Rock Name: porphyritic dacite or rhyodacite intrusive

Number of points counted: 644 Date: July 14, 1972

Slide Quality: good

TEXIURE

Framework:

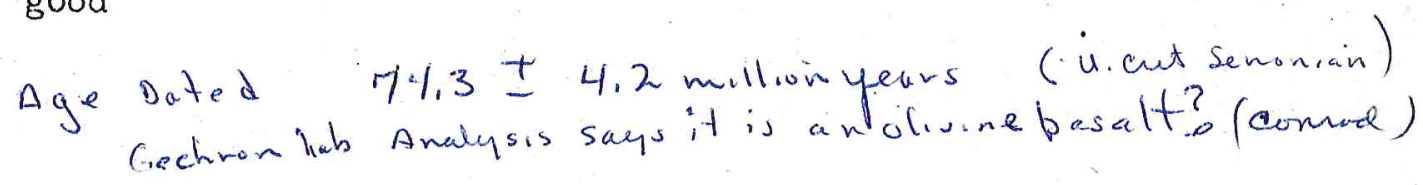

Porosity: 0.6\%; Type: due to plucked grains

Preferred orientation: none

\section{MINERALOGY}

Framework minerals:

Quartz: 13.1\%; Types: euhedral large phenocrysts; slightly reabsorbed or embayed borders

Feldspar: 11.9\%; Types: euhedral phenocrysts of plagioclase

(albite to oligoclase in composition)

Micas: 7.4\%; Type: chlorite fills microwfractures; also replaces quartz and feldspar phenocrysts boundaries

Heavy minerals: $5.4 \%$; Types: 1 . magnetite or ilmenite occurs as small cubes or octahedrons dispersed throughout microcrystalline quartz groundmass;

2. leucoxene occurs as irregular opaque aggregates throughout the groundmass

3. hematite occurs as black opaque stringers or contorted laminae associated with chlorite

Groundmass: 61.3\%; microcrystalline quartz; feldspar microlites and chlorite; interlocking strained microcrystalline quartz and feldspar microlites forms groundmass along with tiny aggregates of chlorite dispersed throughout the section.

SUMMARY

INFERENCES AND CONCLUSIONS

Emplacement: eruption of viscous rhyodacitic/dacitic lava flow, near surface plug, or dome or less likely, may be near surface rhyodacitic dike

\section{Diagenetic History:}

Edges of some euhedral plagioclase phenocrysts altered to zones of chlorite; chlorite forms in groundmass. Devitrification of acidic glass groundmass to interlocking microcrystalline quartz, feldspar, and chlorite. Irregular fractures filled with chlorite, and chlorite oxidized to opaque hematite in part. Fractures formed from stress after magma solidified. 
Thin sections included in Group IV: RRR-391; -392

Age and field relationships (Rosé): Igneous or sedimentary? or combination of the two?, Waring Mountains, southwestern Brooks Range; Waring basin; closely associated with jgneous intrusive and extrusive rocks;

(Niem): lower Cretaceous?

General Comment: Thin section study shows that these are clastic sedimentary rocks; not intrusive igneous; they contain a mixture of recognizable volcanic and sedimentary rock fragments and/or mineral constituents not possibly found in combination in any igneous rock. However, due to extensive diagenetic alteration and abundant matrix in RRR-391 and -392 and the extremely fine grain size of RRR-392 (siltstone wacke), the difficulty in distinguishing the origin in the field is easily understandable; it was difficult even in thin section due to the extensive alteration.

\section{TEXTURE AND CLASSTFICATION:}

RRR-392 is composed of coarse silt-sized clasts suspended in an abundant clay (celadonite) matrix, hence classified as a silty quartz wacke. RRR-39I is a highly altered medium-grained volcanic wacke with abundant green celadonite and brown clay matrix (37.6\%). The matrix is probably authigenic as the altered volcanic rock fragments have indistinct boundaries that merge with the same minerals that compose the matrix. Both samples are poorly to fairly well sorted (if matrix is included). The mineral grains are angular to subangular and rectangular or elongate in shape. Due to abundant authigenic matrix, fair to poor sorting, and general angularity of the clasts, these samples are texturally immature by Folk's classjication.

No preferred orientation of grains was noted. Porosity ranges from high (8.9\%) granular and intergranular in RRR-391 to not measurable in RRR-392 due to much plucking and irregularity in preparation of thin section. 
1. Quartz content is high (37.7\%) in RRR-392 (quartz wacke) and low in RRR-391 (2.5\%). Mostly strained or undulatory variety and equal amounts of mosaic quartz in RRR-391.

2. Plagioclase feldspar high (14.1\%) in RRR-391 but low (trace) in RRR-392.

3. Micas - fibrous celadonite and/or chlorite (8.7\% to $14.7 \%$ ) replaced elongate clasts; also infills pores in matxix.

4. Amphibole - hornblende - (3.8\%) in RRR-392.

5. Pyroxene - trace in RRR-391.

6. Heavy minerals: scattered aggregates of opaque leucoxene and magnetjte/ilmenite in matrix.

\section{Rock fragments:}

1. Chert - $0.4 \%$ in RRR-392

2. Volcanic (in RRR-391) - 13.5\% - flows

a. Pilotaxitic texture

b. Some amygduloidal chlorjte and/or celadonite altered clasts with series of closely packed celadonite filled tubes or vesicles $=$ altered volcanic glass (pumice?)

3. Mudstone $-2.0 \%$ in RRR-391

4. Clay altered rock fragments (unknown composition) $10.2 \%$ in RRR-391

\section{General Comments:}

In general, the finer grained silty RRR-392 sandstone is much more quartz-rich and lacks the rock fragments or plagioclase feldspar of the medium-grained RRR-391 sandstone. This may be a reflection of effect of grain size on determining which mineral and rock fragments exist and in what abundance. Compositionally and texturally RRR-391, the mediumgrained volcanic wacke, is similar to the lower Cretaceous suite of the Waring basin (rolcanic rock fragments, chlorite/celadonite replaced vesicular clasts, abundant plagioclase feldspar, low quartz content, mudstone fragments, and pyroxene), and my opinion is that it is probably early Cretaceous is age。 RRR-391 is quartz-rich like the upper Cretaceous of the Waring Mountains suite but lacks muscovite and does contain hornblende only found in the lower Cretaceous suite of the Waring Mountains. My opinion, based on limited evidence, is that it is early Cretaceous in age and the higher quartz content reflects the grain size effect on mineral. distribution and abundance. 


\section{PROVENANCE:}

RRR-391: major source = volcanic flows possibly intermediate in composition (andesite) suggested by pilotaxitic texture in volcanic rock fragments and tuffs (pumice and volcanic glass) for celadonite/chlorite vesicles replaced clasts; source for feldspar and pyroxene. minor source : fine-grained sedimentary rocks, mudstone or shale, may be penecontemporaneous mud bottom rip-ups; source for quartz.

RRR-392: quartz-hornblende = hornblende andesites or acidic intrusives (granodiorites); source for quartz, too.

quartz-rich rocks - metamorphic or acid igneous; too angular

to be recycled sandstone; may be derived from mudstone or siltstones, however.

\section{COMPOSTRTONAL MATURITY:}

\section{Relief and Climate:}

RRR-392 is compositionally mature, and silt-sized material (abundant quartz) suggests sediment derivation from distant source areas.

Low relief with abundant chemical weathering resulted in reduction of unstable rock and mineral fragments to clay and mechanical breakdown of quartz to very fine grain size.

RRR-391 is compositionally immature (abundant rock fragments) and mediurn grain size suggests derivation from source area of moderate relief with a temperate climate (mechanical weathering dominated over chemical. weathering in vinter season) to produce and remove by erosion abundant rock fragments and compositionally unstable plagioclase feldspar before extensive chemical decomposition to clay. 


\section{DEPOSITIONAL ENVIRONMENT AND TRANSPORTTNG MECHANISM:}

Sample RRR-392 the fine grain size (silt), angularity of framework clasts, and abundant matrix (texturally immature) suggest transport by weak currents and deposition in a low energy quiet water enviroment (e.g. as in deep marine, lakes, swamp, lagoonal environment) to allow very fine quartz and clays to settle out. No reworking by currents. Sample RRR-391 is too extensively altered to determine textural maturity and depositional. environment with certainty. If similar to the other lower Cretaceous rock suite of the Waring Mountains, most likely it was transported by stronger currents than RRR-392 with a competence of moving mediun grained sand, rapidly deposited and buried to produce a fairly well-sorted but angular sediment as in fluvial channels, deltaic channel, or offshore marine near sea cliffs(?).

\section{DIAGENETTC HISTORY:}

1. Complete alteration of mineral clasts to yellowish chlorophaejte and celadonite/chlorite infilling of vesicles in some clasts (as in RRR-391) by celadonite and/or chlorite.

2. Formation of authigenic matrix - brownish clay and celadonite by alteration of volcanic rock fragments in RRR-391 = indistinct boundaries.

3. In RRR-391, feldspar extensively altered to sericite and then fractured and infilled with celadonite.

4. In RRR-392, after lithification, some micro-fracturing and fractures filled with vein quartz precipitated from silica enriched groundwater. 
PETROGRAPHIC REPORT

UNION OIT, COMPANY

North Slope Samples

Sample No. RRR-39I

Analyst: A. R. Niem

Rock Name: highly altered medium-grajned volcanic wacke

Number of points counted: 637

Date: August 22, 1972

Slide Quality: okay; only partial coverage

\section{TEXTURE}

Framework:

Porosity: 8.9\%; Type: granular; in the matrix pores

Median grain size: medium sand; Range: fine to coarse sand

Sorting: fair

Shape and rounding: angular to subangular; prisms, elongate fragments

Textural Maturity (Folk): Probably immature: 1. Abundant authigenic matrix

2. Fair sorting

3. Angular clasts

Preferred orientation: none

\section{MINERALOGY}

Framework minerals:

Quartz: 2.5\%; Type: irregular mosaic quartz clasts (1.9\%) trace of angular silt-sized fragments $(0.6 \%)$

Feldspar: 14.1\%; Type: Plagioclase laths and prisms; highly altered to sericite (and zeolites?); fractures filled with celadonite

Micas: $8.7 \%$; Types: fibrous celadonite replaced elongate clasts; infills vesicles; occurs as aggregates in matrix; chlorite infills pores and replaces clasts

Pyroxene: trace highly altered to sericite and celadonite

Heavy minerals: 2.1\%; Type: leucoxene as opaque rectangular clasts floating in matrix 
Sample No. RRR-391 continued ...

Rock fragments:

Volcanic: $13.5 \%$; lava: 1. Altered clasts still retain pilotaxitic texture of mj.crolites of plagioclase feldspar and magnetite (now altered to leucoxene); some with celadonite or brown clay groundmass

2. Amygduloidal (chlorite or celadonite filled) clasts; some with series of parallel. closely packed tubes (celadonite) in clay

Mudstone: $2.0 \%$ groundmass; looks like altered pumice (volcanic glass)

Extensively altered rock fragnents (unknown composition): 10.2\%

Compositional Maturity (Folk): Immature: altered rock fragments

Diagenetic al teration:

1. Bunches of fibrous radial celadonite or chlorite infill vesicles (which may be amygdules in volcanic rock fragments); no boundaries.

2. Many rock and mineral clasts replaced by predominantly brown to opaque clay or sometimes chlorite or celadonite. Grain boundaries destroyed.

3. Plagioclase feldspar completely altered to sericite or zeolite and fractures filled with celadonite.

Matrix: ( $<.03 \mathrm{~mm}) \quad 37.6 \%$; authigenic, no grain boundaries; some grains are in matrix support.

Types: dark opaque to brownish clay aggregates intermixed with greenish celadonite and light-colored zeolites

SUMMARY

INFERENCES AND CONCIUUSTONS

\section{Provenance:}

Rock types: Although highly altered rock, some outlines of volcanic rock clasts still visible. The extensive degree of alteration suggests the original sediment was composed predominantly of unstable lithic clasts probably volcanic flow rock fragments, altered volcanic glass (amygdules) may be bubble and long tube pumice altered to celadonite.

Thus, source area = volcanic flows, possibly intermediate in composition (andesite), some pilotaxitic texture, and tuffs (pumice and volcanic glass).

Minor source $=$ mudstone or shale, fine-grained sedimentary rocks; may be penecontemporaneous rip-ups.

Relief and Climate: rapid erosion over steep topography in temperate climate produced abundant unstable rock clasts. 
Sample No. RRR-391 continued...

Depositional Environment and Transport Mechanism:

Due to extensive degree of alteration, the textural maturity and depositional environment cannot be readily discerned. Probably it is like that of other less altered sections of lithic wackes in the lower cretaceous suite of the Waring Mountains. Rapid transport jn high energy fluid and rapid deposition and burial to produce fair sorted and angular sediment (e.g. fluvial channels, deltaic channels, offshore marine near sea cliffs).

Diagenetic History:

1. Extensive alteration of rock, particularly volcanic glass (pumice?) and amygduloidal (infilled with chlorite) volcanic flow fragments, and unstable mineral fragments to browish clays, celadonite, and chlorite.

2. Euhedral feldspars extensively altered to sericite and then fractured and fractures were infilled with celadonite.

3. Formation of authigenic matrix from breakdown of rock and unstable mineral fragments; elimination of grain boundaries.

Porosity is high, may be artificially produced by too much grinding in parts of the thin section. 
PETROGRA PHIC REPORT

UNION OIL COMPANY

North Slope Samples

Sample No. RRR-392

Analyst: A. R. Niem

Rock Name: silty quartz wacke

Date: August 5, 1972

Number of points counted: 609

Slide Quality: poor; mostly irregular ground; only small part of section on slide; many man-made fractures as section pulled apart

TEXTURE

Porosity: can not measure; too much plucking and irregularity in grinding; probably low porosity due to abundant clay matxix.

Median grain size: coarse silt

Sorting: well-sorted (if exclude matrix); poorly sorted if include matrix.

Shape and rounding: minerals angular; squarish and rectangular

Textural Maturity (Folk): Irnmature: 1. Abundant clay matrix

2. Good sorting

3. Angular graj.ns

Preferred orientation: none

\section{MINERALOGY}

Framework minerals:

Quartz: 47.1\%; Types: angular quartz; mostly strained extinction; trace of mosaic quartz

Feldspar: trace of plagioclase as long slender laths with Carlsbad twinning

Amphiboles: $3.8 \%$; Type: hornblende

Heavy minerals: $0.8 \%$; Types: magnetite/ilmenite; leucoxene

Celadonite: $14.7 \%$

Rock fragments:

Chert: $0.4 \%$

Compositional Maturity (Folk): mature to supermature: mostly quartz with some hornblende

Diagenetic alteration:

Unknown mineral completely altered to celadonite clasts 
Matrix: ( $<.03 \mathrm{~mm}$ ) 32.9\%; can not tell if original or authigenic; possibly authigenic

Types: celadonite (greenish clay) as yellow-green aggregates or very fine platelets around framework grains

SUMMARY

INFERENCES AND CONCLUSTONS

\section{Provenance:}

Rock types: same source as for the volcanic arenites of the lower Cretaceous but finer grained; possibly rock fragments destroyed.

Quartz-rich rock = metamorphic or igneous; too angular to be recycled sandstone; may be redeposited quartz derived from mudstone, shales, or siltstone, however.

Hornblende $=$ hornblende andesites or intermediate or acidic intrusives

Relief and Climate: possibly low relief; chemical weathering predominant $=$ reduction of unstable rock and mineral fragments to clay and mechanical weathering breakdown of quartz to very fine grain size.

\section{Depositional Environment and Transport Mechanism:}

Low energy quiet water to allow very fine quartz and clays to settle out (such as in deep water, lakes, swamp, lagoonal). No reworking as indicated by abundance of clays.

\section{Diagenetic History:}

1. Alteration of mineral clasts completely to yellow-green chlorophaeite and celadonite and partly to clay matrix.

2. After lithification, some micro-fracturing and fractures filled with vein quartz. 
Thin sections included in Group V: RRR-276, 359, and 348

Age and field relationships (Rose): Devonian sandstone sequence cropping out in northwestern part of Schwatka Mountains of Brooks Range: source terrain may be Ne ruokpuk (Precambrian - Silurian)

RRR-348 - probably Devonian(?) compared with RRR-359 for similarity

\section{CLASSTFICATION:}

RRR-276 is a pebbly medjum-grained quartz arenite, and RRR-359 is a coarse-grained carbonate cemented subfeldspathic lithic arenite. On the other hand, RRR-348 is a coarse-grained subfeldspathic lithic wacke.

\section{TEXYURE:}

The Devonian sandstones, RRR-359, 276, and 348 are similar to each other in that they are coarse-grained (except RRR-276), poorly sorted, and contain very angular to subangular framework minerals (many grains are elongate in shape). Texturally, RRR-276 and 359 are mature (angular grains and poor sorting but lack matrix) whereas RRR-348 (Devonian?) is immature (contains abundant diagenetic matrix, $14.5 \%$ micaceous clays and zeolites?).

The grains in RRR-359 have no preferred orientation, but in sample RRR-348 the clasts are aligned perpendicular to the long direction of the thin section. There is a suggestion of preferred orientation to some of the clay laminae in RRR-276.

Porosity is low (less than 1\% in RRR-276; $2.5 \%$ in RRR-359; $3 \%$ in RRR-348) due to extensive hematite and carbonate cementation of pores, and alteration of grains. These sandstones do not have a good potential as petroleum reservoirs unless later tectonically fractured or have undergone later groundwater solution of carbonate cement elsewhere.

In summary, texturally RRR-359 and 348 are similar in grain size, sorting, and angularity of framework minerals, but RRR-359 has no matrix whereas RRR-348 contains abundant diagenetically formed clay matrix (14.5\%) and has a preferred orientation of mineral clasts. 


\section{MINERALOGY:}

The quartz content is high (24.3\% to $31.3 \%$ ) in RRR-359 and RRR-276, but low (5.6\%) in RRR-348. Non-undulatory or normal quartz is twice as abundant as mosaic quartz in RRR-359 and RRR-276; but, on the other hand, mosaic or polycrystalline quartz is more abundant ( $3.4 \%$ ) than normal quartz $(2.2 \%)$ in RRR-348.

Feldspar: very low content is all three sandstones. 0.1\% plagioclase feldspar in RRR-3L8; none in RRR-359 and RRR-276.

Micas: muscovite and sericite flakes range from only a trace to $1.6 \%$ in RRR-276 and in RRR-359, whereas in RRR-348 mica and micaceous or sericite replaced clasts are quite abundant (21.9\%).

Heavy minerals: are similar in all three sections. They include leucoxene aggregates and filaments (traces in RRR-276 and 359, up to $7 \%$ in RRR-348), trace of hematite and zircon in RRR-276 and a trace of green tourmaline in RRR-359.

Pyroxene: RRR-348, however, is distinctively different from RRR-359 in that RRR-348 contains abundant (1.5.4\%) colorless clinopyroxene (pigeonite?), and RRR-359 and RRR-276 contain none.

\section{Rock fragments:}

1. Chert is extremely abundant $(55.5 \%)$ in RRR-276 (the only rock fragment that is pebble-sized), high (16.8\%) in RRR-359 and Iow $(3.2 \%)$ in RRR-348; some clasts contain micro quaxtz veins.

2. Mudstone (6.6\% and 5.5\%) occurs in both RRR-359 and RRR-348; none in RRR-276.

3. Only a trace of schist and siltstone in RRR-359.

4. RRR-348 is the only sample to contain recognizable altered volcanic lava flow fragments and possible carbonate altered shard structures and celadonite/chlorite replaced clasts.

5. Both RRR-359 and 34.8 have large carbonate replaced clasts (up to 20\% in RRR-348), and some carbonate and limonite cement. RRR-276 contains a hematite cement.

In summary RRR-359 and RRR-348 are similar in mineralogy in some respects in that they contain quartz, chert, muscovite or sericite, and carbonate altered replaced clasts, leucoxene, and similar anounts of mudstone rock fragments. But the relative abundance of these minerals in each section is strikingly different (particularly in the amount of quartz and chert, mosajc to normal quartz). The abundance is reversed in the two samples.

Also even though RRR-359 and RRR-348 are of the same grain size and. sorting, there are striking differences in the mineralogy in other respects. RRR-348 contains abundant clinopyroxene (20.3\%), altered volcanic rock and tuff fragments (2.6\%), trace of plagioclase feldspar whereas RRR-359 does not contain any of these mineral and rock fragments. 


\section{MINERALOGY continued . .}

On the other hand, traces of schist clasts, siltstone grains, and green tourmaline occur in RRR-359, but not in RRR-348. RRR-348 contains abundant diagenetically formed micaceous clay matrix (indistinct grain boundaries of volcanic rock fragments that merge with matrix of similar composition) whereas RRR-359 has no matrix.

Thus, there are striking differences in mineralogy in these two Devonian samples particularly in terms of the abundance of pyroxene, quartz, and chert, and in the occurrence of volcanic rock fragments in one but not the other. The quartz and chert-rich mineralogy of Devonian sample RRR-359 is more similar to the upper Cretaceous rocks of the Waring Mountains while the amount of volcanic rock fragments, pyroxene, and low quartz content, and chert content of Devonian sample RRR-348 is more like the lower Cretaceous rock mineralogy in the Waring basin. In conclusion, RRR-348 and RRR-359 appear to be strikingly different in mineralogy from what one would expect for the same formation and grain size and my educated guess is that they are not obviously related mineralogically.

RRR-359 has undergone extensive carbonate replacement of unknown clasts, perhaps these were once pyroxene and volcanic fragments once similar to RRR-348. However, this is unlikely. 
PROVENANCE:

Major source: quartz and chert-rich terrane for RRR-359 and 276.

Chert clasts may be derived from sedimentary source rocks; that is, chert nodules eroded from limestone beds or deep-water chert beds, or may have formed from devitrification of acidic volcanic glass.

Minor source: fine-grained sedinentary rock, mostly mudstone - some siltstone; may also be penecontemporaneous mud bottom rip-ups; this provenance could also be a source for muscovite and fine quartz in these sandstones.

Minor source: low-grade metamorphics = source for clasts of mica schist and quartzite or gneiss for RRR-359; metamorphic provenance could be also source for quartz with strained or undulatory extinction and muscovite flakes.

Mosaic quartz: derived from vein quartz or metamorphic quartzite sources.

Volcanic flows for RRR-348 - probably basic and/or intermediate volcanic lava; source for volcanic rock fragments, and clinopyroxene (pigeonite?) from basalt flows.

Tuff source for RRR-348; ash falls source for the carbonate replaced glass shards(?).

\section{COMPOSTT IONAL MATURITY:}

\section{Relief and Climate:}

RRR-276 is compositionally supermature (87\% chert and quartz). RRR-359 is mature to supermature, mostIy quartz and chert, some sedimentary rock fragments, and RRR-348 is immature due to abundant mineralogically unstable clinopyroxene and some volcanic fragments.

High mineralogical maturity of RRR-276 and RRR-359 suggest derivation of sediment that form these sandstones from low-lying source areas (10w or gently rolling topography) in a warm humid tropical or temperate climate that resulted in extensive chemical destruction of most unstable minerals and rock fragments to clay, thus enriching the sediments in chert and quartz. Slow erosion removal of unstable material due to gentle topography, enhanced effect of chemical breakdown of unstable minerals. In contrast, RRR-348 is mineralogically immature suggesting mechanical weathering processes dominated over chemical weathering processes at times (such as temperate climate with winters) in which a steep relief in the source area facilitated more rapid erosion or removal of the unstable pyroxene and volcanic rock fragment-rich detrjtus before extensive chemical weathering could reduce the detritus to clays. The source for RRR-348 may be closer. More samples need to be studied to determine climatic conditions and relief. 


\section{DEPOSITIONAL ENVIRONMENT AND TRANSPORTING MECHANISM:}

The moderate textural maturity of $R R R-348,276$, and 359 suggests extensive winnowing of fines as little original matrix remains, but current transport was not extensive or prolonged enough to sort and round the quartz and chert detritus to any significant degree as suggested by the . general poor sorting and angularity of the sandstone. RRR-276 appears to be a bimodal mixture of two grain sizes, suggesting origin from two sources (chert pebbles and medium-grained quartz); many unstable rock fragments probably destroyed by extensjve abrasion in RRR-276. Some mudstone fragments may be current rip-ups of the penecontemporaneous mud bottom in RRR -359 and 348. Their occurrence in RRR-359 and 348 suggests no extensive or prolonged abrasion as these are soft unstable clasts and are easily destroyed. Current competence was strong enough to move medium to coarse sand. Current orientation in RRR-348. Low degree of sorting and rounding in RRR-348 suggests rapjd burial and no extensive current reworking (not surf). Probable enviromments: RRR-276 = littoral; RRR -348 and $35^{\prime} 9=$ delta or fluvial channel or marine.

\section{DIAGENETIC HISTORY:}

1. Compaction extensive - as evidenced by contorted appearance of mudstone clasts and mica clasts which are also penetrated by adjacent quartz grains in RRR-348; extensive interpenetration of grain boundaries by pressure solution of chert and quartz clasts suggests a deep burial.

2. Oxidation of iron minerals to leucoxene, Iimonite, or hematite and precipitation of these iron oxides by groundwater in the interstices between grains as a cement.

3. Complete replacement of unknow minerals and of feldspar and volcanic clasts in RRR-348 by carbonate and by micaceous clay minerals; destruction of grain boundaries and formation of diagenetic micaceous clay matrix in RRR-348. Carbonate rhombs in RRR-359 replaced interior of chert clasts and also carbonate and limonite replaced grain boundaries of quartz and mosaic quartz grains to produce irregular edges. Alteration most extensive in RRR-359 and 348, and very little in RRR-276. 


\section{PETROGRA PHIC REPORT}

UNTON OIL COMPANY

North Slope Sarmples

Sample No. RRR-276

Analyst: A. R. Niem

Rock Name: pebbly medium-grained quartz-cherty arenite

Number of points counted: 1243

Date: June 20, 1972

Sljde Quality: good

\section{TEXTURE}

Framework:

Porosity: Jess than 1\%; Type: possibly plucked particles

Median grain size: medium sand; Range: very fine sand to pebbles

Sorting: poor; bimodal $=$ pebbles and medium sand

Shape and rounding: irregular, subangular to angular grain boundaries due to extensive interpenetration of quartz grains; large framework clasts approach spherical shape; smaller framework clasts are elongate in shape

Textural Maturity (Folk): Moderately mature: 1. Iittle matrix

2. Poor sorting

3. Angular to subangular

Preferred orientation: none, although some clay laminae parallel. aligned at $45^{\circ}$ angle to long direction of thin section

\section{MINERALOGY}

Framework minerals:

Quartz: 31.3\%; Types: clear quartz with strained extinction (18.2\%); some quartz with straight extinction; polycrystalline or mosaic quartz ( $5.0 \%)$; micro quartz veins $(8.1 \%)$ in chert and quartz clasts

Micas: trace; Types: contorted muscovite flakes between chert and quartz grains

Heavy minerals: trace of magnetite; leucoxene; hematite (octahedron shape); euhedral zircon crystals

Rock fragments:

Chert: 55.5\% - largest clasts are chert, cryptocrystalline quartz; some chert contains micro quartz veins

Compositional Maturity (Folk): Supermature: almost entirely chemically resistant quartz, chert, and hematite 
Sample No. RRR-276 continued...

Diagenetic alteration:

1. Oxidation of ixon-rich minerals to hematite and minor leucoxene; remobilization of some hematite by solution around grain boundaries (cementing agent); some recrystallization and orientation of micaceous clay minerals forming matrix.

2. Pressure solution caused extensive interpenetration of chert and quartz clasts destroying original quartz boundaries. This suggests deep burial and stress (producing strained or undulatory quartz) and also produced contortion of clay laminae; resulted in extreme reduction of porosity.

Later tectonic(?) fractures filled with precipitated quartz from pressure solution (cut across grain boundaries and matrix).

Matrix: $(<.03 \mathrm{~mm}) \quad 3.9 \%$ original matrix

Type: micaceous clay (not diagenetic because no lithic grains or unstable minerals present to form from and all the framework grains have distinct boundaries).

Cement: $8.7 \%$; no cement as quartz overgrowths

Types: hematite - aggregates of hematite grains bind chert and quartz framework clasts and also some of the micaceous clays may be
acting as a cement

SUMMA RY

INFERENCES AND CONCLUSTONS

Provenance: Rock types: quartz- and chert-rich provenance; quartz may be recycled

1. Chert - may be sedimentary in origin, e.g. deep-water chert beds or nodules from limestone beds; or may have formed from devitrification of acidic volcanic glass.

2. Polycrystalline or mosaic quartz strained and interpenetrated crystalline quartz derived from quartz veins or quartzite.

3. Euhedral magnetite or zircon suggest first cycle origin from basic volcanics, igneous plutons, or metamorphics

Relief and Climate: gentle or low stream gradients resulted in slow erosion and transport allowing extensive chemical destruction of unstable mineral and rock clasts. Warm and humic temperate climate resulted in extensive destruction of unstable minerals and rock fragments; only quartz, chert, and magnetjte remain. This conclusion is suggested by mineralogic maturity.

Depositional Environment and Transport Mechanism:

Moderate textural maturity suggests winnowing of much of the fines; little matrix remains, although depositional process was not extensive enough to sort the material or perhaps there was a mixing of two sources quartz). Extensive abrasion may have (coarsest size in cherts; finer in minerals (such as on anstable chert; quartz rounding is obscured subsequent concentration of quartz and chert; quartz rounding is obscured by diagenetic history but euhedral magnetite 
Sample No. RRR-276 continued...

Depositional Environment and Transport Mechanism continued...

grains suggest little abrasion of these clasts (first cycle of sedimentation). Small magnetite grains settled at same rate with larger but less dense chert and quartz grains. Coarse grain size suggests current deposition as in marine (littoral) or fluvial; not wind (too coarse-grained).

Diagenetic History: see diagenetic alteration

Very low porosity - this sandstone has a very poor potential as a reservoir for petroleun unless fractured or jointed. 
PETROGRAPHIC REPORT

UNION OIL COMPANY

North Slope Samples
Analyst: A. R. Niem

Rock Name: coarse-grained subfeldspathic lithic wacke

Number of points counted: 614 Date: August 21, 1972

Slide Quality: good, missing on one edge

\section{TEXTURE}

Framework:

Porosity: 3.0\%; Type: granular; pores between grains

Median gxain size: coarse sand: Range: fine to very coarse sand

Sorting: poor

Shape and rounding: angular elongate clasts

Textural Maturity (Folk): Immature to mature: 1. Authigenic matrix

2. Poor sorting

3. Angular grains

Preferred orientation: clasts are aligned almost perpendicular to long direction of thin section

\section{MINERALOGY}

Framework minerals:

Quartz: 5.6\%; Types: elongate clasts of polycrystalline (mosaic) quartz (3.4\%), quartz with strained extinction and occasional mica inclusions and microstylolitic or serrated crystalline boundaries (2.2\%) trace of angular, clear quartz

Feldspar: 0.1\%; Type: trace of plagioclase feldspar, prism-shaped Micas: 21.9\%; Types: abundant mica and elongate fibrous micaceous clasts; replacement of minerals or rock clasts

Pyroxene: 15.4\%; Type: clinopyroxene (pigeonite) - anhedral to prismatic shape, colorless crystals with high relief

Heavy minerals: 7.3\%; Type: leucoxene occurs as irregular anhedral aggregates and filaments

Carbonate: 20.3\%; carbonate replaced large angular elongate clasts (small carbonate crystal aggregates to large carbonate crystals); carbonate also infills fractures in pyroxene. 
Sample No. RRR-348 continued...

Rock fragments:

Chert: $3.2 \%$; cryptocrystalline quartz occurs as oblong fragments; abundant fibrous micaceous clay minerals cut through clasts

Volcanic: 2.6\%; ghost outlines of extensively altered volcanic lava flow clasts containing feldspar microlites replaced by micaceous clay and/or carbonate in opaque iron oxide groundmass; some clasts with stretched volcanic shard structure - may be pumice or welded ash flow tuff fragment; tuff fragments altered extensively to carbonate.

Mudstone: 5.5\%; mudstone or shale clasts = elongate fragments composed of brown or opaque clay and iron oxides; some contain dark contorted filaments or fibers of carbonaceous matter or iron oxides

Compositional Maturity (Folk): Immature: abundant chemically unstable pyroxene

Diagenetic alteration:

1. Irregular patches of carbonate replaced large elongate clasts of unknown composition; some carbonate associated with mosaic quartz or zeolites(?) replacing clasts. Volcanic fragments extensively altered to clay and iron oxides.

2. Fibrous and contorted micaceous clay (sericite?) replaced elongate clasts penetrated by resistant minerals.

3. Some celadonite/chlorite replaced clasts.

Matrix: (<.03 mm) 14.5\%; diagenetic origin; many completely altered mineral and rock fragments of same composition as matrix. Grains have indistinct boundaries that merge with matrix.

Type: fibrous micaceous clay minerals and zeolites(?).

Cement: minor amounts of carbonate and iron oxides (leucoxene) outline mineral and rock clasts; some may be pore-filling cement.

SUMMARY

INFERENCES AND CONCLUSIONS

Provenance:

Rock types: 1. Clinopyroxene (pigeonite) = phenocrysts from basalt flows or from diabase or dolerite sills.

2. Basalts and/or intermediate (andesite) volcanic lava = source for altered volcanic rock fragments; also source for plagioclase; carbonate replacement of volcanic glass shards(?) suggest tuff source or ash falls in source area.

3. Fine-grained sedimentary rock $=$ source for mudstone or shale, or these clasts may be penecontemporaneous current rip-ups of the mud bottom.

4. Chert $=$ sourced either from devitrified acidic volcanic glass or sedimentary chert beds or chert nodules from limestone beds. 
Sample No. RRR-348 continued ...

Relief and Climate: Mechanical weathering predominated over chemical. weathering as in a cool temperate climate facilitated retention of unstable minerals (pyroxene) and volcanic rock fragments; steep relief (hills) resulted in rapid erosion.

Depositional Environment and Transport Mechanism:

Much of matrix of diagenetic origin. Orientation of coarse clasts, poor sorting, and angularity of clasts suggest high energy current transport, deposition, and burial in a rapidly subsiding area (geosyncline?) with high rates of sedimentation. Iittle or no reworking of this poorly sorted angular rock and mineral detritus. Enviroments of deposition may be subsiding delta channels, fluvial, or if marine, offshore littoral near mouth of high energy river or near sea cliffs (rugged coastline).

Diagenetic History:

1. Extensive compaction resulted in contorted and crushed appearance of sedimentary rock fragments.

2. Extensive replacement of feldspar and rock clasts (mainly volcanic) by carbonate and by a fibrous micaceous clay mineral and zeolites? destruction of framework grain boundaries; formation of diagenetic micaceous clay matrix and infilling of pore space by carbonate cement. Oxidation and hydration of iron mineral (ilmenite) to leucoxene stringers and aggregates. The pyroxene minerals resisted most alteration processes. 
PETROGRA PHTC REPORT

UNTON OIL COMPANY

North SIope Samples

Sample No. RRR-359

Analyst: A. R. Niem

Rock Name: coarse-grained carbonate cemented (or altered?) subfeldspathic Iithic arenite

Number of points counted: 600

Date: July 15, 1972

Slide Quality: okay

TEXIURE

Framework:

Porosity: 2.5\%; Type: intragranular, probably grains plucked out of section or artifjcial cracks

Median grain size: coarse sand; Range: very fine to coarse sand

Sorting: poor

Shape and rounding: very angular; elongate quartz

Textural Maturity (Folk): Mature: 1. Fines winnowed

2. Angular clasts

3. Poor sorting

Preferred orientation: none

\section{MINERALOGY}

Framework minerals:

Quartz: 24.3\%; Types: clasts of polycrystalline or mosajc quartz (8.7\%) with strained extinction and straight crystal boundaries; some strained mosaic quartz with serrated crystal boundaries (may be quartzite); clean quartz grains with serrated grain boundaries where boundaries replaced by carbonate and iron oxides (15.6\%)

Micas: 1.6\%; Types: a few flakes of muscovite; also sericite (a micaceous mineral completely replacing clasts of unknown composition)

Heavy minerals: trace; Types: green tourmaline inclusion in quartz grains; leucoxene/limonite

\section{Rock fragments:}

Chert: 16.8\%; cryptocrystalline quartz; some clasts contain isolated carbonate crystals, tiny mica flakes, and/or irregular

Schist: trace dark contorted laminae cutting across grains.

Siltstone: trace 
Sample No. RRR-359 continued...

Rock fragments: continued...

Mudstone: $6.6 \%$; elongate dark very fine-grained carbonaceous (fibrous laminae) clasts contain a few siltsized quartz or mica flakes; some brown clay clasts; some argillite clasts with aggregate polarization

Compositional Maturity (Folk): Mature to supermature - very high abundance of quartz and chert; a few sedimentary rock fragments

Diagenetic alteration: extensive

Many edges of quartz, mosaic quartz, and chert grains are serrated or embayed by solution and replaced by carbonate and iron oxides.

Cement: $47.8 \%$; none as quartz overgrowths

Types: Carbonate occurs as extensive replacement of mineral grains. Many carbonate crystals are rhombs. Sone may be pore fillings; others penetrate and replace chert and other lithic fragments. Extensive amounts of leucoxene/limonite form dark irregular mottled cement aggregates in the interstices between grains and in the carbonate replaced grains.

SUMMARY

INFERENCES AND CONCLUSIONS

\section{Provenance:}

Rock types: 1. Siltstone and carbonaceous mudstone derived from finegrained sedimentary rocks; some may be penecontemporaneous current rip-ups of the mud bottom.

2. Polycrystalline or mosaic quartz = vein quartz or metamorphic source.

3. Muscovite $=$ probably mica schist source or acidic plutonic

4. Schist fragment - low-grade metamorphic source

5. Argillaceous chert = sedimentary rocks - chert beds or chert nodules from limestone beds

Relief and Climate: moderate to low relief resulted in slow erosion of detritus allowing extensive chemical weathering of unstable lithic clasts and unstable mica minerals to produce a sediment enriched in chert and quartz (warm, humid tropical. or temperate climate).

Depositional Environment and Transport Mechanism:

Current deposited such as on a delta/fluvial channel or shallow marine sand and current scour ( $r i p$-up) of underlying cohesive carbonaceous muds and silts. Fines winnowed but rapid deposition with little reworking or abrasion to produce angular grains. Otherwise, soft sedimentary clasts would have been destroyed. 
Diagenetic History:

Complete replacement of lithics or mineral of unknown composition by carbonate; partial replacement of interiors of chert by carbonate rhombs. Solution of edges of chert, mosaic quartz, and quartz grains and replacement by carbonate and limonite to produce serrated grain boundaries on clasts. Growth of carbonate and simultaneous precipitation of iron oxides resulted in incorporation of opaque iron oxides in carbonate rhombs. Oxidation of iron-rich minerals and extensive precipitation from groundwater of. limonite and some leucoxene in the interstices between grains as a cement.

Porosity is very low due to extensive limonite and carbonate cementation and replacement. This rock has a poor reservoir potential. 
SUMMARY - Group VI

Thin sections included in Group VI: RRR-323, INA-374, RRR-333, and 336; $R R R-310$

Age and field relationships (Rosé): Jurassic-Cretaceous graywacke-type rocks deposited just north of front of western Brooks Range; source area to the south from the Brooks Range. RRR-310 also Jurassic.Cretaceous but from Delong Mountaing of the western Brooks Range.

\section{CLASSIFICATTON:}

The first four samples all arenites (lithic, volcanic feldspathic, and quartz types) and range in grain size from very fine-grained sandstone to coarse-grained sandstones. RRR-310 is a carbonate cemented Iithic granule conglomerate. The low matrix content ( $<4.2 \%)$ in these sandstones classify them as arenites, not as wackes. They also lack metamorphic clasts and mica, the presence of which would have classified them as graywackes under an older classification.

\section{TEXTURE:}

Grain size ranges from very fine-grained sandstone to granule conglomerate. The sandstones are good to moderately sorted except RRR-310, the granule conglomerate, which is poorly sorted. Rock fragments in the medium- and coarse-grained sandstones are well-rounded to subrounded while the quartz is still angular. The clasts are typically. more angular in the finer grained sandstones.

The diagenetic matrix ranges from a trace to $4.2 \%$. The average is 1.4\%. It is composed of greenish celadonite and/or opaque clay. There are sone indistinct grain boundaries (merge with matrix) on the volcanic rock fragments suggesting a diagenetic origin for the matrix.

These samples are texturally mature to supermature in Folk's classification (sample DWA-374 is supermature) based on the low amount of matrix, moderate to good sorting, and the higher degree of rounding of the rock fragments than of the quartz grains.

Some preferred orientation was noted in these samples. RRR-336 and DWA-374 contain a fine-grained lamination and elongate grains in RRR-310 are aligned. Porosity ranges from low (2.0\%) to moderate (6.7\%) and is of the granular and intergranular types.

Cement, mainly carbonate, occurs as an abundant pore filining and ranges from $8.4 \%$ to $43.7 \%$. Iron oxide, leucoxene, and celadonite act as a minor cement. Quartz overgrowths occur in none of the samples except in DWA -374 which contains $3.0 \%$ quartz overgrowths. 


\section{MINERALOGY:}

Quartz is abundant in these samples ( $12.0 \%$ to $46.2 \%$; average: $30.1 \%$ )。 It is most abundant in the medium and finer grained sandstones. Strained or undulatory quartz is the most commonly occurring variety. Mjcrographic quartz (some grains with green tourmaline inclusions) is present in RRR-333 and mosaic or polycrystalline quartz is less common ( $3.4 \%$ to $11.0 \%$ ) than normal quartz in all sections.

Feldspar is the second most abundant mineral in this suite (1.1\% to 11.0\%). The following types of feldspar are present:

1. Albite twinned plagioclase feldspar is most comon (andesine to albite in composition).

2. Trace of untwinned feldspar, possibly orthoclase?

3. Feldspar is most abundant in the medium- and coarse-grained sandstones.

Micas (trace to 4.6\%) mostly green fibrous celadonite/chlorite occur as authigenic or replacement product; trace of muscovite or biotite in $\mathrm{RRR}-310,323,333$, and 336.

Amphiboles (9.9\% in RRR-333; 6.8\% in DWA-374; trace in RRR-31.0) pleochroic green hornblende

Heavy minerals $(0.5 \%$ to $4.0 \%)$ mostly opaque iron oxides, leucoxene, and hematite; trace of magnetite/ilmenite and yellowish zircon.

Rock fragments:

Volcanic lava flow clasts very abundant type of rock fragment

1. Intersertal and pilotaxitic texture; microlites of plagioclase feldspar and opaque iron oxide in celadonite, chlorite, or iron oxide groundmass; (trace to $12.7 \%$ )

2. Trace of chlorite and cryptocrystalline quartz replacing altered glass shards.

Sedimentary:

Mudstone $(0.4 \%$ to $27.8 \%)$ most abundant rock rragment type in RRR-323; occur as the following types:

1. dark carbonaceous variety contains spherulites of mosaic quartz (recrystallized radiolaria?) and sponge spicules.

2. Most common type is clast of browish fine-grained clay; some contain contorted dark clay laminae.

Siltstone (0 to $13.4 \%$ in RRR-310)

Fine-grained sandstone: $0.4 \%$ in RRR-310

Chert: $(0.6 \%$ to $10.8 \%$ ) cryptocrystalline quartz; few contain feldspar phenocrysts.

Metamorphic - very low abundance to non-existence in the sandstones

1. Quartzite $(0.6 \%$ in RRR-310)

2. Quartz mica schist (0.4\% in RRR-336) 
MINERALOGY continued ...

Rock fragments continued...

Acidic plutonic (granodiorite or quartz diorite) $0.4 \%$ in RRR-323 to $1.3 \%$ in RRR-310; occurs only in the coarser grained samples; consists of interlocking crystalline quartz and plagioclase feldspar and rarely untwinned feldspar (orthoclase?)

Carbonate replaced clasts $0.9 \%$ to $15.3 \%$

\section{PROVENANCE:}

Major source: intermediate (hornblende andesites) and basaltic volcanic flows source for hormblende, plagioclase feldspar (andegine); some volcanic ash in DWA-374, altered pumice and shards

Major source: fine-grained sedimentary rocks, shale or carbonaceous mudstone with radiolaria(?) (deep-water marine); some siltstone and rare fine-grained sandstone (also source for quartz); some mudstone could be penecontemporaneous current rip-ups of mud bottom

Moderate source: chert - some bedded deep-water sedimentary chert beds (ghosts of recrystallized radjolaria in RRR-310), chert nodules in limestone beds, or in some cases where chert contains phenocrysts of feldspar probable source from devitrification of acidic volcanic glass.

Minor source: acid intrusive - possibly granodiorite or quartz diorite; source for plutonic fragment; rare muscovite, hornblende, quartz (including micrographic quartz), and plagioclase feldspar (oligoclase)

Very minor source: low-grade metamorphjc, trace of possible quartzite and quartz mica schist fragments in two thin sections; also source for quartz and minor muscovite.

Moderate source: mosaic quartz, probably vein quartz from sedimentary terrane as micro-veinlets of mosaic quartz cut sedimentary rock fragments (mudstone) in RRR-310; secondary source may be quartzite.

Provenance is best deciphered from the coarser-grained sandstones that contain rock fragments. 


\section{COMPOSITIONAT MATURITY:}

Inmature to mature in Folk's classification. Coarse-grained sandstones are immature as they contain abundant unstable rock fragments. Fine-grained sandstones are mature because the quartz content is high and there are fewer unstable mineral and rock fragments.

\section{Relief and Climate:}

Steep relief such as hills and mountains with high stream gradients to rapidIy carry away unstable rock and mineral fragments from the site of weathering before complete chemical decomposition. Probably derived under a temperate climate where mechanical weathexing predominated over chemical weathering at times (such as during winter) to produce unstable rock and mineral detritus and not predominantly clay. Only exception in RRR-336 which is a very fine-grajned quartz-rich sandstone without rock fragments suggesting derivation from a source with low to moderate relief where chemical weathering destroyed most unstable rock and minerals thereby enriching the sediment in quartz and forming the very fine grain size.

\section{DEPOSITIONAL, ENVIRONMENT AND TRANSPORTING MECHANISM:}

Textural maturity suggests current deposition by fairly high energy currents with competence to carry granules and coarse sand, to winnow out most fines, and to produce faix sorting. The softer lithic volcanic and mudstone fragments were rounded by transport over long distances. The soft mudstone clasts may be, in part, penecontemporaneous rip-ups of the mud bottom by current scour; They are not likely deposited in sure zone or they would have been destroyed by constant abrasion. Changes in current energy formed laminations of various grain sizes in DWA-37L and orientation of granules in RRR-310. Probably fairly rapid burial after deposition because in general the quartz and feldspar are angular. Probable environments $=$ fluvial or deltaic channels, or offshore marine littoral sands (near sea cliffs); DWA-374 has a high textural maturity (some wellrounded quartz and feldspar, good sorting, and no matrix) probably offshore bar, beach? strandline deposit. RRR-336 is a very fine-grained laminated sandstone, probably deposited by weak current carrying very fine-grained material including muscovite which settled slowly in low energy environment with abundant carbonate mud(?); such environments as lagoonal swamp, or protected bay, tidal flats, of deep marine. 
1. Minor compaction: well-packed sandstone, but quartz grains do not show pressure solution effects nor are rock fragments crushed.

2. Alteration of feldspars to scattered patches of sericite.

3. Extensive alteration of groundmass of volcanic rock fragments to greenish celadonite, opaque iron oxides (mainly leucoxene), dark brown clay, chlorite, and more rarely to carbonate or hematite. Destruction of volcanic grain boundaries in RRR-333.

4. Celadonite, chlorite, or carbonate completely replaced mineral and/or rock clasts of unknown affinities. Precipitation of some quarti overgrowths in INA -374 .

5. Precipitation of mainly carbonate and/or hematite (or leucoxene). cement by ground water in remaining pore spaces between grain boundaries. May be recrystallized calcareous mud in RRR-336 since it is so abundant and quartz grains are floating in it. Some tectonic(?) fractures in lithified RRR-310 which was later infilled with carbonate. No carbonate cement in RRR-333 but cement is leucoxene and celadonite. 
GENERAL COMMENTS:

The general mineralogy of this Jurassic-Cretaceous suite of the northwestern Brooks Range and Delong Mountains is similar to that of the lower Cretaceous rocks of the Waring basin in southwestern Brooks Range in that both suites contain volcanic rock fragments (hornblende andesites and basalts), plagioclase feldspar (oligoclase and andesine), untwinned. feldspar (orthoclase), abundant mudstone rock fragments, chert, plutonic rock fragments (granodiorite or quartz diorite), and very low percentage of quartzite or schist. This Jurassic-.Cretaceous suite tends to have a little higher abundance of quartz, have less diagenetically formed matrix, and more rounded grains and is better sorted than the lower Cretaceous suite of the Waring basin suggesting slightly more agitated environments for the Jurassic-Cretaceous suite and more winnowing of clays. But both suites appear to have the same type of provenance in the Brooks Range which apparently shed detritus north and south into the Waring basin and the Delong Mountains. Since these Jurassic-Cretaceous rocks are similar in texture and mineralogy to that of the lower Cretaceous, it is suggested that the bulk of them may be lower cretaceous in age. They do not resemble the muscovite and schist-rich quartz sandstones of the upper Cretaceous of the Waring basin. They are also distinct from the lower Cretaceous of the Waring Mountains (Group II) in that many of the sandstones contain extensive carbonate cement.

RRR-310, from the Delong Mountains, is coarser grained (granule conglomerate) than the other Jurassic-Cretaceous sandstones but like the other coarser Jurassic-Cretaceous sandstones, it is poorly sorted, lacks matrix, and the rounding of the rock fragments is good. Being coarser grained, the Delong sample contains a larger variety and general greater abundance of rock fragments than the other coarse-grained. JurassicCretaceous sandstones, but these clasts are the same kinds and only occur in the slightly different relative abundance, that is, both contain basaltic and intermediate volcanics, siltstone is more abundant than mudstone, and acid plutonic rock fragments, and vein quarta fragments. All occur in carbonate matrix. Hence, RRR-310 is similar in mineralogy and some textural characterisitcs to the coarser Jurassic-Cretaceous sandstones although formed in a different place. 
PETROGRA PHIC REPORT

UNION OIC COMPANY

North Slope Samples

Sample No. RRR-323

Analyst: A. R. Niem

Rock Name: coarse-grajned lithic (mudstone-volcanic) arenite

Number of points counted: 620

Date: August 5, 1972

Slide Quality: Good, except it is a small section and only covers center of slide

\section{TEXTURE}

Framework:

Porosity: 6.7\%; Types: pores, intergranular

Median grain size: coarse sand; Range: medium sand to granule

Sorting: fair

Shape and rounding: Volcanic, chert, and mudstone clastg are well-rounded; quartz and feldspar are angular, equidimensional or prismatic in shape; some well-rounded quartz grains

Textural Maturity (Folk): mature: 1. Lack of fines

2. Poor sorting

3. Many soft rock fragments well-rounded but hard quartz still angular

Preferred orientation: none

\section{MINERALOGY}

Framework mj.nerals:

Quartz: 15.2\%; Types: angular quartz, mostly strained or undulatory extinction (11.0\%); some quartz with tourmaline inclusions

mosaic quartz or polycrystalline quartz

$(4.2 \%)=$ interlocking crystalline quartz with microstylolitic or sutured boundaries; some contain mica flakes.

Feldspar: 5.3\%; Type: plagioclase feldspar (oligoclase-andesine) with albite twinning

Micas: 1.1\%; Types: celadonite and chlorite replacing clasts; trace of muscovite

Heavy minerals: 4.0\%; Types: opaque iron oxides - leucoxene

Carbonate: 14.6\%; occurs as irregular aggregates partiy replacing volcanic rock fragments, plagioclase feldspar, and chert 
Sample No. RRR-323 continued...

\section{Rock fragments:}

Chert: $4.6 \%$; occurs as rounded fragments; some clasts contain micro quantz veins

Volcanic: 12.7\%; occurs as rounded fragments with plagioclase feldspar laths in opaque iron oxide and celadonite groundmass; both pilotaxitic and intersertal textures are present

Siltstone: 3.7\%; large clast of abundant angulax quartz, iron oxides cemented by carbonate.

Mudstone: 27.4\%; some laminated mudstone clasts with dark aligned iron oxides interrupted by spherulites of radial chalcedony (possibly recrystallized forams); also mudstone, shale, and argillite occur as wellrounded clasts of dark opaque clays and iron oxides with some angular silt-sized quartz and mica floating in this matrix; some fragments have micro quartz veins (mosaic quartz) cutting through them.

One rounded spiculite mudstone fragment consists of sponge spicules as long slender curved needles of mosaic quartz tapered at one end, in finegrained matrix of iron oxides and clay

Plutonic: 0.4\%; large rounded acidic plutonic clast with interlocking crystals of plagioclase feldspar and quartz

Compositional Maturity (Folk): Immature: abundant large chemically unstable volcanic and sedimentary rock fragments

Diagenetic alteration:

1. Plagioclase grains altered to patches of sericite.

2. Groundmass of volcanic fragments altered to iron oxides, chlorite, or celadonite.

Matrix: (<.03 mm) 3.8\%; mostly original; some diagenetically formed (boundaries of some volcanic rock fragments not distinct)

Types: dark clay and iron oxides; same clay that makes up shale and mudstone fragments scattered around edges of framework grains

Cement: none as quartz overgrowths

Type: carbonate occurs as pore filling cement as well as alteration mineral of other mineral and rock fragments 
Sample No. RRR-323 continued ...

SUMMARY

INFERENCES AND CONCLUSTONS

\section{Provenance:}

Rock types: 1. Predominantly fine-grajned sedimentary rock shale, mudstone, siltstone, argillite (slate?) as wellrounded fragments; some may be current rip-ups of the mud bottom; other laminated mudstones contain possible recrystallized radiolaria or forams and one spiculite (sponge spicules) suggest erosion of fine-grained deep water marine sedimentary rocks.

2. Volcanic flows

3. Quartz = may be metamorphic, plutonic or the few well-rounded grains probably are recycled from sedimentary sources

4. Mosaic quartz = a source associated with rein quartz; some micro quartz veins (nosajc quartz) in some chert and mudstone clasts suggest vein quartz source associated with sedimentary rocks.

5. Chert $=$ sedimentary nodules in limestone, deep-water bedded chert, or devitrified acidic volcanic glass

6. Minor source $=$ acidic plutonic intrusive (granodiorite or quartz diorite); also source for quartz grains.

Relief and Climate: steep relief = hills; rapid erosion over steep gradient resulted in rapid removal and transport of chemically unstable rock fragnents. Temperate or cold climate; mechanical weathering predominant over chemical weathering to produce many chemically unstable rock fragments and mineral grains.

Depositional Environment and Transport Mechanism:

Fair sorting, good rounding in some clasts, and winnowed clay suggest an agitated environment, some transport, and rapid deposition. The soft sedimentary rock fragments round rapidly and would not hold up in a surf environment with continuous abrasion; probably they are current rip-ups in an offshore littoral or fluvial channels or deltaj.c environment.

Diagenetic History:

1. Little compaction.

2. Carbonate replaced some feldspar, volcanic rock fragments and is also precipitated from solution as pore filling cement.

3. Celadonite/chlorite formed as alteration product of groundmass of volcanic rock fragments.

4. Initial formation of sericite patches on plagioclase feldspar. 
PETROGRAPHIC REPORT

UNION OII COMPANY

North Slope Samples

Sample No. DWA -374

Analyst: A. R. Niem

Rock Name: medium-grained lithic (volcanic and feldspathic) arenite

Number of points counted: 749

Date: August 3, 1972

Slide Quality: good, but carbonate minerals too thick

(thin section not ground down enough)

TEXTURE

Framework:

Porosity: 2.0\%; Type: granular.

Median grain size: medium sand; Range: fine to medium sand

Sorting: good

Shape and rounding: hornblende: subrounded to well-rounded spheres and prisms

quartz: subangular to subrounded equidimensional grains. and spheres

rock fragments: subangular to subrounded clasts

Chert: wel].-rounded grains

Textural Maturity (Folk): mature to supermature: 1. No matrix

2. Sorting good

3. Many clasts

well-rounded

Preferred orientation: yes, a few fine laminations of smaller grains perpendicular to long direction of thin section

\section{MINERA LOGY}

Framework minerals:

Quartz: 46.2\%; Types: clear, rounded to angular grains; strained quartz most common type (24.0\%); some quartz with tourmaline, muscovite, and rutile inclusions; a possible grain of graphic intergrowth of quartz;

mosaic quartz $=$ interlocking polycrystalline quartz with sutured or microstylolitic boundaries (11.9\%); a common mosaic quartz variety consists of interlocking elongate blades of quartz (10.3\%)

Feldspar: 11.0\%; Types: plagioclase (andesine) albite twinned

$(8.4 \%)$; some pericline twinning and oscillatory zoned twinned feldspar $(2.6 \%)$; trace of microcline and untwinned orthoclase. 
Sample No. DWA-374 continued...

Framework minerals: continued ...

Micas: 4.6\%; Types: chlorite replaces some volcanic clasts Amphiboles: 6.8\%; Type: hormblende, pleochroic green grains, good cleavage

Heavy minerals: 2.0\%; Types: opaque iron oxide; magnetite; ilmenite cubes; altering in part to hematite; yellow zircon inclusions in feldspar

\section{Rock fragments:}

Chert: $1.7 \%$ occurs as cryptocrystalline quartz in some well-rounded equant grains; some contain feldspax phenocrysts suggesting a volcanic origin (chert formed from devitrification of acidic glass)

Volcanic: 10.9\%; Types: pilotaxitic and intersertal textures (aligned and randomily oriented slender feldspar microlites in celadonite, chlorite, cryptocrystalline quartz, or iron oxide groundmass); occasional magnetite grains occur between feldspars in volcaric clasts.

Punice and shards: trace occurs as vesicular clasts of devitrified cryptocrystaliine quartz and chlorite (shard outlines)

Vesicular chlorite replaced clasts: trace: vesjcular green chlorite; vesicles filled with quartz (amygdules)

= devitrified bubble wall shards?

Siltstone and mudstone: $1.8 \%$; mudstone, shale and argillite occurs as dirty elongate micaceous clay clasts with patches of opaque iron oxides. Minor siltstone fragnents consist of abundant angular quartz, mica, and feldspar in a clay matrix.

Compositional Maturity (Folk): Immature: many volcanic rock fragmentg and unstable minerals includj.ng plagioclase feldspar and hornblende

Diagenetic a]teration: 1. Plagioclase feldspar altered to scattered patches of. sericite and partly replaced by carbonate in some cases.

2. Volcanic rock fragments and volcanic glass, pumice and shards altered to celadonite and chlorite.

Matrix: ( $<.03 \mathrm{~mm}$ ) 4.2\%; original matrix; grain support; no obvious breakdown of rock fragments; grain boundarjes are distinct.

Type: fine opaque clay outlines boundaries of grains (may be leucoxene)

Cement: $8.4 \%$; about $30 \%$ of the cement occurs as quartz overgrowths

Types: Carbonate cement infills pores; quartz cement as overgrowths on quartz grains; iron oxides as minor pore filling cement. 
Sample No. DWA-374 continued...

SUMMARY

INFERENCES AND CONCLUSTONS

\section{Provenance:}

Rock types: 1. Main source = intermediate lava flows . hornblende andesites, some basalt.

2. Chert $=$ clasts with phenocrysts of feldspar are devitrified acidic glass source; other clasts may be sedimentary or volcanic in origin.

3. Volcanic ash = supply for volcanic glass?; vesicular pumice and shards now altered to chlorite/celadonite with quartz and chlorite filled amygdules?

4. Quartz = derived from acidic intrusives, vein quartz sources, or metamorphic sources. Some well-nrounded grains may be recycled.

5. Mosajc quartz $=$ vein quartz

6. Fine-ngrained sedimentary source (mudstone, shale, argillite, slate, siltstone); mudstone may be also penecontemporaneous ripped-up clasts of mud bottom by currents.

Relief and Climate: steep relief; mountains or hilly topography; rapid erosion in order to preserve the unstable rock fragments and minerals from chemical disintegration. Mechanical weathering prevailed over chemical weathering at times as in a cool temperate climate; producing much chemically unstable rock and mineral detritus.

Depositional Environment and Transport Mechanism:

Laminations (formed by concentrations of heavy opaque minerals and different grain sizes) suggest a deposition by pulsating currents of various high and low energies; currents had the ability (competence) to move medium-grained sand. The lack of matrix, good sorting, and occurrence of well-rounded hornblende, some quartz, chert, and volcanic rock fragments suggest deposition in a hj.gh energy environment with a long history of reworking (abrasion and movement back and forth) such as surf, shallow water littoral, strandline deposits. Too coarse-grained to be eolian.

\section{Diagenetic History:}

1. Well compacted.

2. Alteration of volcanic rock fragments (and glass?, pumice) to celadonite and chlorite.

3. Precipitation from groundwater solutions of quartz overgrowths on quartz grains (in optical continuity with grains) resulted in cementing of some of the grains. Then precipitation of carbonate and hematite in pores.

4. Feldspars altered to patches of sericite.

5. Porosity is low due to cementation and alteration of grains not good potential as petroleum reservoir rock. 
PETROGRAPHTC REPORT

UNION OTI COMPANY

North Slope Samples

Sample No. RRR-333

Analyst: A. R. Niem

Rock Name: fine-grained feldspathic arenite

Number of points counted: 631. Date: August 3, 1972

Slide Quality: fair; only center of slide contains rock section

TE XTUURE

Framework:

Porosity: 2.5\%; Type: granular and intergranular

Median grain size: fine sand; Range: very fine to fine sand

Sorting: fair to well-sorted

Shape and rounding: quartz $=$ angular, spherical to equidimensional in shape, some elongate;

feldspar and hornblende = prismatic shape

Textural Maturity (Folk): Mature: 1. No matrix

2. Sorting fair to good

3. But grains very angular

Preferred orientation: none

\section{MINERALOGY}

Framework minerals:

Quartz: 39.9\%; Types: clear quartz mostly with undulatory or strained extinction, mainly microstylolitic or sutured. contacts with other quartz grains (30.9\%); a few quartz grajng with green tourmaline inclusions; trace of micrographic intergrowth of quartz; mosaic quartz $(9.0 \%)$ - clear polycrystalline quartz containing crystalline quartz units that have strained extinction and mostly straight contacts; some radial. fjurous chalcedony varieties

Feldspar: 14.5\%; Types: plagioclase (andesine to albite in composition) prisms (11.1\%) albite twinned and altered to scattered patches of sericite; some quartz inclusions intergrown with feldspar prisms; minor: untwinned feldspar (orthoclase?) altered to patches of sericite $(3.4 \%)$

Micas: trace; types: biotite and muscovite flakes; chlorite Amphiboles: 9.9\%; Type: hornblende: Heavy minerals: $3.9 \%$; Type: trace of magnetite/ilmenite; mostly hematite/leucoxene outline grain boundaries

Carbonate: $0.9 \%$; occurs as occasional patches 


\section{Rock fragments:}

Chert: $0.6 \%$

Volcanic: $12.5 \%$;

Mudstone: $1.1 \%$
Types: pilotaxitic texture = aligned slender crystals of Carlsbad twinned feldspar intersertal =: random orientation of slender crystals of twinned feldspar dark opaque clasts containing few silt-sized quartz, feldspar, and mica fragments

Compositional Maturjty (Folk): Immature to mature: many volcanic rock fragments and unstable feldspar and hornblende; even though quartz content is high

Diagenetic alteration:

Many volcanic rock fragments are extensively altered to green celadonite or opaque iron oxides resulting in indistinct grain boundaries that merge with matrix; only aggregates of aligned slender plagioclase crystals mark the site of the altered volcanic fragments; alteration of squarish hornblende and some chert to patches of opaque leucoxene and green celadonite giving the clasts a mottled appearance; also boundaries of some quartz grains are replaced by celadonite giving sutured or nicrostylolitic appearance.

Matrix: $\quad(<.03 \mathrm{~mm})$ trace of authigenic matrix

Type: some celadonite may act as matrix

Cement: 13.7\%; none as overgrowths

Type: thin film of celadonite (diagenetically formed) and leucoxene outline boundaries of grains and act as cement between grains

SUMMARY

INFERENCES AND CONCLUSTONS

\section{Provenance:}

Rock types: 1. Predominantly volcanic = intermediate flows (hornblende andesites) as source for volcanic rock fragments, hornblende; and plagioclase feldspar (andesine); some basalt(?) source

2. Chert $=$ sedimentary chert nodules derived from limestone or sedimentary bedded chert or from devitrified acidic volcanic glass

3. Mosaic quartz $=$ probably vein quartz; less likely recrystallized quartzite (no orientation of crystalline quartz units); some rnicro quartz veins in volcanic rock fragments suggesting volcanic terrain may be source for large mosaic quartz clasts; radiating fibrous chalcedony may be sedimentary source or devitrified acidic volcanic glass.

4. Mudstone $=$ derived from fine--grained sedimentary rocks or penecontemporaneous rip-ups of cohesive bottom sediment. 
Sample No. RRR-333 continued...

Rock types continued...

5. Quartz = too angular to be recycled sedimentary; may be either acidic igneous or metamorphic or individual clasts derived from vein quartz

6. Trace of graphic intergrowth of quartz suggests plutonic quartz (possibly acidic intrusive)

Relief and Climate: Steep relief; rapid erosion removed unstable rock fragments and minerals before chemical destruction. Probably cool temperate or arctic(?) climate where mechanical

weathering processes dominated over chemical processes, at least at times, to produce abundant rock fragments instead of clays and quartz.

Depositional Enviromment and Transport Mechanism:

Current transport, rapid exosion, deposition and burial (e.g. geosynclinal); winnowing of fine clays and sorting of clastic debris produced a finegrained fairly well-sorted sandstone. Angulaxity of grains suggests rapid burial. and no reworking (certainly not surf zone; more likely fluvial, deltaic, or offshore marine). Although RRR-33.3 has same mineralogy as the caarse-grained volcanic arenites in this Jurassic-Cretaceous sandstone suite (such as DWA-374), it contains a greater abundance of quartz; probably because the soft unstable volcanic rock fragments and minerals were destroyed at this finer grain size and are thus not as abundant, concentrating the harder and more resistant quartz. Also there may have been more quartz available at the source area for this sandstone.

\section{Diagenetic History:}

1. Compaction produced closely and well-packed sandstone but was not too extensive as there is little pressure solution of quartz or crushing of grains.

2. Feldspar altered to patches of sericite.

3. Groundmass of volcanic rouk fragments altered to celadonite, chlorite, and opaque dark clay or iron oxides (leucoxene), rarely to carbonate or hematite; this alteration resulted in the destruction of fragment boundaries.

4. Celadonite and chlorite completely replace mineral clasts of unknown original composition.

5. Diagenetic iron oxide (hematite/leucoxene) and mainly celadonite precipitated as cement in pores between grain boundaries; carbonate cement rare as pore filling.

Porosity is low - poor potential as a reservoir. 
PETROGRA PHIC REPORT

UNTON OIL COMPANY

North Slope Samples

Sample No. RRR-336

Analyst: A. R。 Niem

Rock Name: very fine-grained carbonate-.cemented quartz arenite

Number of points counted: 625 Date: June 29, 1972

Slide Quality: poor - only a partial section

TEXTURE

Framework:

Porosity: 4.0\%; Type: particle shaped pores - either plucked or dissolved by diagenesis

Median grain size: very fine sand; Range: coarse silt to fine sand

Sorting: well-sorted

Shape and rounding: angular, with embayed grain boundaries

Textural Maturity (Folk):

1. Mature if cement is diagenetically precipitated from solution after burjal.

2. Immature if cement is recrystallized primary calcareous mud

Preferred orientation: faint lamination parallel to elongate direction of slide; framework grains floating in carbonate cement.

\section{MINERALOGY}

Framework minerals:

Quartz: $38.7 \%$; Types: 1. angular strained quartz, high embayed grain boundaries $(35.3 \%)$

2. mosaic quartz, angular, highly embayed grain boundaries $(3.4 \%)$

3. trace of micrographic quartz

Feldspar: 3.5\%; Types: angular plagioclase with embayed grain boundaries, and much alteration to sericite

Micas: $0.6 \%$; Types: muscovjte, trace of biotite

Heavy minerals: 2.5\%; Types: leucoxene, opaque ilmenite or magnetite; zircon

\section{Rock fragments:}

Chert: $5.7 \%$

Schist: $0.4 \%$

Mudstone: $0.4 \%$

Organic fragments: elongate thin carbonate fragments, may be gastropod or clam shell fragments. 
Sample No. RRR-336 continued...

Compositional Maturity (Folk): Mature to supermature: mostly quartz and chert; no lithic fragments; minor feldspar

Diagenetic alteration: extensive alteration of plagioclase grains to carbonate and replacement of plagioclase and quartz grain boundaries (embayed) by carbonate; carbonate replacement of muscovite.

Matrix: $\quad(<.03 \mathrm{~mm})$ trace

Cement: $43.8 \%$; none as quartz overgrowths

Types: carbonate cement occurs as platy aggregates between grains, very fine grain size looks like recrystallization of carbonate mud (rheomorphism); primary origin of carbonate mud is suggested because the framework grains are floating in carbonate cement; some may be carbonate cement precipitated as pore fillings.

SUMMARY

INFERENCES AND CONCLUSIONS

\section{Provenance:}

Rock types: 1. Acidic plutonic or metamorphic = biotite

2. Acidic plutonic = micrographic quartz

3. Quartz and plagioclase-rich provenance, e.g. plutonic or metamorphic; too angular to be recycled from sedimentary rocks

4. Composite or mosaic quartz = vein quartz or quartzite

5. Mica $=$ plutonic, metamorphic or recycled sedimentary rocks

6. IImenite/magnetite $=$ plutonic, metamorphic, or recycled sedimentary rocks

Relief and Climate: lowlands, gentle; allowed extensive chemical destruction of unstable rock fragments to clay minerals; resistant minerals quartz and chert broken down by mechanical means and chemical means to very fine grain size.

Depositional Environment and Transport Mechanism:

Quartz, plagioclase, and mica flakes settled in a very low energy environment (fine grain size) that contained calcareous mud such as a lagoon, swamp, protected tidal flat, or deep marine; no current reworking; no eolian transport because grains are too angular; some weak currents to produce weak lamination.

\section{Diagenetic History:}

*1. Recrystallization of carbonate mud to carbonate cement aggregates

OR 2. Extensive alteration of plagioclase grains and other unstable rock fragments and minerals and precipitation of aggregates of carbonate in pore spaces.

3. Oxidation of iron mineral to leucoxene.

*History \#1 is preferred.

Porosity is very low; tightly cemented; not a good reservoir. 
PETROGRAPHIC REPORT

UNION OIL COMPANY

North Slope Samples

Sample No. RRR-310

Analyst: A. R。 Niem

Rock Nane: carbonate cemented lithic granule conglomerate

Number of points counted: 716

Date: August 13, 1972

Slide Quality: good, thin section too thin on one edge

TE XTPURE

Framework:

Porosity: 2.9\%; Type: mostly intergranular and some granular

Median grain size: granules; Range: fine sand to granules

Sorting: poor

Shape and rounding: many well-rounded equidimensional lithic clasts; some angular

Textural Maturity (Folk): Mature: 1. Lacks matrix

2. Sorting poor (nixture of two sources?)

3. Rounding good to fair

Preferred orientation: some suggestion that long axes of grains aligned perpendicular to long direction of slide

\section{MINERALOGY}

Framework minerals:

- Quartz: 12.0\%; Types: rounded clasts $(8.7 \%)$, most with strained extinction;

polycrystalline or mosajc quartz (vein quartz $(3.3 \%)$ clasts with strained extinction, interlocking crystalline quartz contain serrated or microstylolitic boundaries; some mosaic quartz contains blades of quartz intergrowths radiating inward from boundaries of elongate clasts = vein quartz; some micro quartz veins in siltstone fragments; some well-rounded quartz fragments

Feldspar: 1.1\%; Types: trace of plagioclase feldspar; albite twinned prisms; few as framework clasts; most in rock fragments;

untwinned feldspar (orthoclase?)

Micas: 2.6\%; Type: trace of muscovite flakes

Amphiboles: trace of hornblende altered to chlorite/celadonite Heavy minerals: $0.5 \%$; magnetite 
Samples No. RRR-310 continued...

Carbonate: carbonate filled veinlets cut across section; crystals of carbonate also replace feldspar

Fibrous celadonite (minor chlorite) completely replace well-rounded light greenish clasts.

\section{Rock fragments:}

Chert: 10.8\%; cryptocrystalline quartz; some chert with dark contorted laminae; other chert type (minor). composed of intergrowth of fibrous quartz or chalcedony; some chert with silt-sized angular quartz and mosaic quartz infilling spherical cavities (forams that have been recrystallized?) floating in crypto crystalline quartz matrix.

Volcanic: 8.2\%; well-rounded spherical clasts of volcanic flow fragments with an intersertal texture (random orientation of microlites of feldspar and opaque iron oxides in celadonite, chlorite or opaque leucoxene groundmass).

Quartzite: $0.6 \%$; possible quartzite fragments composed of interlocking elongate crystalline quartz. The crystalline quartz is intexgrown with mica in a subparallel alignment.

Siltstone: 13.4\%; clasts consist of poorly sorted angular silt-sized quartz, feldspar, and mica (biotite and muscovite) in a fine clay (or carbonate) or iron oxide matrix.

Mudstone: 4.8\%; mudstone or shale; dark black opaque carbonaceous (carbon-rich) siliceous varieties $(4.6 \%)$ wi.th spherulites (recrystallized radiolaria? and sponge spicules?) filled with mosaic quartz and chalcedony; some semi-rounded laminated varieties;

other varieties: brownish fine-grained clay clasts with dark patches of iron oxides; some with dark contorted laminae

Carbonate replaced clasts: 15.3\%; large carbonate clasts formed by carbonate replacement of rock fragments (some may be limestone clasts); the clasts consist of fine-grained sparry calcite infilled with rhombs of dolomite (appears to be replacement of other minerals in a chert fragnent); in one large fragment of Iimestone, sparry calcite infills many spherical cavities (recrystallized formainifera(?) or volcanic vesicles); the cavities are outlined by iron oxides; some clasts are composed entirely of micrite (fine calcareous mud)

Plutonic: 1.3\%; acidic plutonic intrusive (granodiorite), equant grains of plagioclase feldspar, untwinned. feldspar (orthoclase?), and quartz interlocking granular texture; feldspar altered to sericite.

Sandstone: $0.4 \%$; very fine-grained sandstone; mainly silt and sand sized angular quartz and some plagioclase feldspar and minor mica in fine-grained clay matrix. 
Compositional Maturity (Folk): Immature: abundant rock fragments

Diagenetic alteration:

1. Celadonite/chlorite replaces both entire clasts (original composition unknown) and the groundmass of volcanic clasts; only feldspar microlites and magnetite renain; also various degrees of carbonate replacement of volcanic and siltstone clasts

2. Carbonate replaces feldspar also.

Matrix: $\quad(<.03 \mathrm{~mm})$ trace

Cement: $20.8 \%$; none as quartz overgrowths

Types: mainly carbonate cement in pore spaces between clasts; minor amounts of celadonite cement associated with carbonate cement Minor cement = mainly opaque hematite and some leucoxene coats framework grains.

SUMMARY

INFERENCES AND CONCLUSTONS

\section{Provenance:}

Rock sources: 1. Mainly fine-grained sedimentary, shale, carbonaceous mudstone with recrystallized radiolaria(?) (deep-water marine?), siltstone, and fine-grained sandstone; some mudstone could be penecontemporaneous current rip-ups of mud bottom; could be some limestone source.

2. Chert source $=$ deep-water cherts; some clasts contain ghosts of radiolaria or, less likely, origin for some is from devitrification of acidic volcanic glass.

3. Some volcanic flows, intermediate and basaltic volcanics = source for volcanic clasts; some carbonate replaced.

4. Minor acidic plutonic source - granodiorite, possibly diorite in composition; also serves as source for quartz

5. Very minor metamorphic, possible quartzite clasts

6. Mosaic quartz, probably vein quartz, some micro quartz veins cut across sedimentary clasts suggesting the vein quartz source was associated wi th sedimentary terrain.

7. Muscovite $=$ plutonic or metamorphic source

Relief and Climate: Steep relief, hills, high stream gradients, rapidly carried lithic detritus away from site of weathering before chemical decomposition. Mechanical weathering predominated over chemical weathering at times (as in cool temperate climate) to produce abundant chemically unstable rock and mineral detritus.

\section{Depositional Environment and Transport Mechanism:}

Deposition by high energy mechanism; strong current to carry granule size detritus; finer detritus clays winnowed; rounding of lithics by transport over long distance; scouring of mud bottom to produce mud chips; rapid deposition as sorting still poor; probably fluvial/littoral offshore (e.g. rugged coastline) depositional environment. 
Diagenetic History:

1. Minor compaction.

2. Extensive alteration of some volcanic lithic groundmass to celadonite and opaque iron oxides. Partial to complete replacement of clasts by diagenetic carbonate and celadonite. Alteration of feldspar to sericite.

3. Oxidation ond precipitation of hematite cement on grain boundaries; also partial replacement of some clasts by hematite.

4. Precipitation of carbonate cement in remaining pore spaces between grajin boundaries.

5. Minor solution of some unknown minerals to produce a granular porosity. Fracturing of lithified rock. Rock fractures infilled with precipitated carbonate from groundwater. Porosity low due to cementation and alteration - poor reservoir potential. 
SUMMARY - Group VII

Thin sections included in Group VII: Upper Cretaceous: RRR-412, 413, 414, $416,478,421,424,426,431$ and lower Cretaceous: RRR- 435 and 440

Age and field relationships (Rosé): Foothills of eastern Brooks Range; southwest through southeast of Sagwon; the source for al 1 the samples lies in the Brooks Range;

Samples RRR -435 and 440 should be similar to each other; source in Brooks Range and probably strandline deposits as are the other samples from the Sagwon area.

\section{CLASSIFICATTON:}

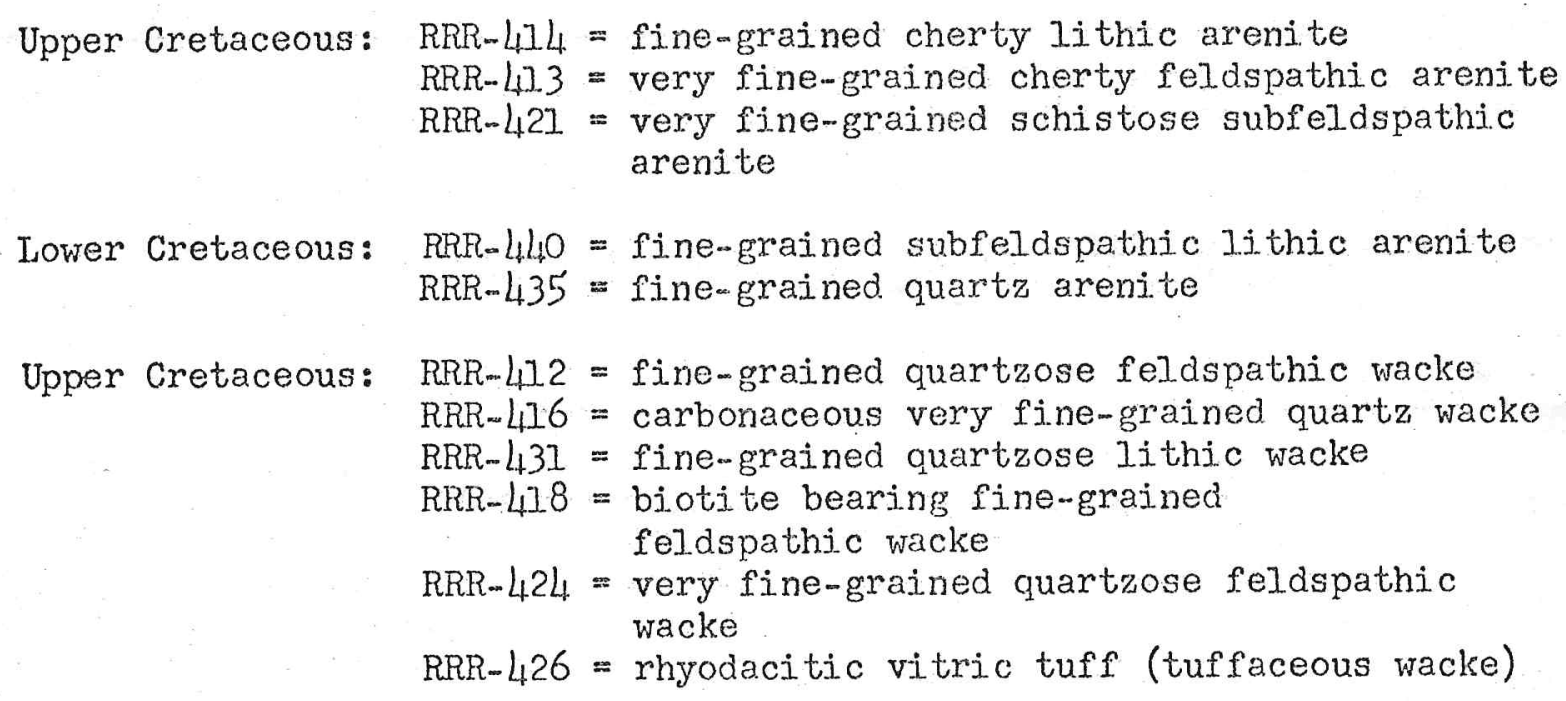

Two lower Cretaceous and three upper Cretaceous samples are quartz or subfeldspathic lithic arenites and one feldspathic arenite. Five upper Cretaceous rocks are predominantly quartzose feldspathic wackes with one quartz and lithic wacke. All the samples are quartzose (quartz-rich). One upper Cretaceous sample is vitric tuff or tuffaceous sandstone (wacke).

\section{TEXTURE:}

All upper and lower Cretaceous samples of the Sagwon area are very. fine-grained to fine-grained sandstones. These upper and lower Cretaceous sandstones are, in general, finer grained than the samples from the upper and lower Cretaceous of the Waring basin and the Jurassic-Cretaceous samples north of the Brooks Range in the Delong Mountains. The framework clasts are well-sorted to moderately sorted (excluding clay matrix) and better sorted, in general, than the upper and lower Cretaceous rocks of the Waring basin. Most of the framework clasts are angular to subangular. Only in RRR-418 are the clasts subangular to subrounded. Most of the clasts are elongate slivers or prisms. 
Five samples are wackes with clay matrix (mixtures of greenish celadonite, brown or colorless clays or zeolites(?), cryptocrystalline quartz, and opaque iron oxides ranging from 1.1.0\% to $29.4 \%$. The matrix is, in part, authinal. (distinct boundaries between framework grains and matrix) to partly authigenic (indistinct rock fragment boundaries altered to the same kind of material that forms the matrix). Matrix is very high (52\%) in RRR-426, a vitric tuff, and consists of brownish clay with an admixture of iron oxides and silt size quartz around volcanic shards. Clay matrix is very low. in the four arenites (trace to $3.8 \%$ ).

The arenites, except RRR-435, are cemented with pore-filling carbonate (17.2\% to 33\%) and minor hematite cement. The wackes also, in general, contain large amounts of carbonate, some celadonite, and hematite or leucoxene cement, (trace to $22.3 \%$ ). RRR-431 contajns $7.2 \%$ quartz overgrowths
as cement.

Porosity ranges from low to very high $(1.5 \%$ to $15.8 \%$ ). The average is high $(7.7 \%)$ and is best in the arenites. Porosity is mostiy the intra. plucking produced in the matrix with some granular and is due to artificial preparation of the thin sections. The moderate solution of $2 \%$ ) in tuff sample RRR-426 is a granular variety due to lower Cretaceous Cretaceous rocks of the Waring Moun area is also high in the upper probably the best potential petrol eum

The only preferred orientation was observed in RRR-L18 (due to orientation of mica and schist fragments), in RRR-416 due to aligned carbonaceous matter, RRR-424, and faint lamination found in RRR-413. AII samples are in framework grain support except RRR-426, the tuff, in which shards and quartz grains are floating in $52 \%$ clay matrix.

Texturally, the lower Cretaceous arenite samples RRR-440 and 435 and upper Cretaceous arenite samples RRR-414 and 421 are mature with little or no clay matrix. (less than 10\%), fair sorting, but angular and subangular clasts. The upper Cretaceous wacke samples, on the other hand, are texturally immature; that is, they contain abundant matrix (some of which is authigenic and some original), angular elongate grains, and the material excluding the matrix is moderately to well-sorted. 


\section{MINERALOGY:}

Quartz is the most abundant mineral in this suite. It ranges from $32 \%$ to $68.7 \%$ excluding tuff saxple RRR-426 where quartz is low (5.0\%). This high quartz content is similar to that of the quartzmrich upper Cretaceous rocks of the Waring basin and unlike the low quartz content of the lower Cretaceous rocks of the Waring basin. It is slightly more abundant than the quartz content in the Jurassic-Cretaceous suite of the northwestern Brooks Range although the fine grain size may also account for the quartz richness (most other rock fragments and unstable minerals break dow and are destroyed at this grain size). The most abundant quartz types are clear undulatory and non-undulatory extinction varieties, followed by a lower abundance of mosaic or polycrystalline quartz (0.4\% to $7.7 \%$ ). RRR-440, 435, and 431 contain some quartz with inclusions consisting of trains of bubbles, iron oxides, rutile or yellow tourmalines. A trace of micrographic intergrowth of quartz and feldspar occurs in RRR-4ill.

Feldspar content in general is low (0 to 7.9\%), predominantly plagioclase feldspar with albite and raxe pericline twinning, followed by untwinned feldspar (k-spar or orthoclase), and a trace of microcline in RRR-478. Feldspar abundance is lower than, the lower Cretaceous rocks of the Waring basin and more like that of the upper Cretaceous of the Waring basin and the Jurassic-Cretaceous rocks northwest of the Brooks Range.

Micas $(0.4 \%$ to $4.4 \%)$ consist predominantly of flakes of muscovite with lesser amounts of biotite (trace to $0.9 \%$ ) and chlorite. Although biotite and muscovite are less abundant relative to other mineral types, it is a characteristic mineral in these upper and lower Cretaceous suites. The abundance of muscovite and biotite is much higher than in the lower cretaceous rocks of the Waring basin and Jurassic-Cretaceous rocks of the northwestern Brooks Range and comparable to the amount found in the upper Cretaceous rocks of the Waring basin. The micas in the lower Cretaceous of the Waring basin and the Jurassic-Cretaceous rocks are diagenetic chlorite and celadonite replaced clasts.

Pyroxene and amphibole - only a trace of colorless pyroxene in RRR-4l2, 413, 416, 418, and 431. Significantly, there is a lack of green hornblende (traces only) and/or pyroxene in this upper and lower Cretaceous suite in the northeastern Brooks Range similar to the upper Cretaceous sandstone suite of the Waring basin, but unlike the lower Cretaceous sandstones of the Waring Mountains and the coarser grained sandstones of the JurassicCretaceous group. No pyroxene or hornblende was recognized in the two lower Cretaceous samples of the Sagwon area.

Heavy minerals (trace to $6.4 \%$ ); fairly low content of heavy minerals compared to other Cretaceous suites. Most abundant heavies are opaque iron oxides (hematite, leucoxene, magnetite and/or ilmenite) with trace amounts in some samples of apatite, zircon, green tourmaline, and epidote.

Other minerals: glauconite $(0.5 \%)$ in RRR-435 carbonate replaced minerals (including feldspars) $7.2 \%$ in RRR- 424 ; $1.1 \%$ in RRR- 426 
Rock fragments:

Percentage abundance of rock fragments is quite low; may reflect fine grain size of samples; rock fragments do not normally occur in such fine sizes.

One of the more abundant rock fragment types in this suite is chert.

Chert content is generally low (trace to 11.5\%) except in RRR-414.

Volcanic rock fragments - very low content: some lava fragments with pilotaxitic texture (intermediate composition) and intersertal texture (feldspar microlites in celadonite groundmass) (basa]t composition). The abundance of volcanic lava flow rock fragments is non-existent to very low (trace to $3.2 \%$ ) in this upper and lower Cretaceous suite of the Sagwon area compared to the volcanicrich lithic sandstones of the lower Cretaceous of the Waring basin and the Jurassic-Cretaceous rocks of the northwestern Brooks Range. The low content of volcanic rock fragments is similar to the upper Cretaceous of the Waring basin. The low content of volcanic rock fragments encountered here might reflect the effect of grain size also as rarely does one find fine to very fine-grained volcanic rock fragments in abundance.

The celadonite/chlorite amygduloidal replaced clasts and altered volcanic glass of the lower Cretaceous of the Waring Mountains are also missing in this suite.

Volcanic glass shards are abundant (29.7\%) only in RRR-426, dacitic or rhyodacitic tuff. They are mostly sickle-shaped, some bubble wall, and bubble shards of fine ash size. They are associated with quartz and acidic plagioclase feldspar. Some have original acidic volcanic glass; others are partially replaced by chert or the zeolite analcime(?) and/or heulandite.

Metamorphic - schist (trace to $12.2 \%$ ). The percentage of schist fragments ranges from low to moderately high. Most samples contain a few percent of schist fragments except tuff sample RRR-L26. The abundance of schist fragments in this upper and lower Cretaceous suite is similar to the abundance in the upper Cretaceous Waring basin suite, but it contrasts with the lower Cretaceous suite of the Waring Mountains and the Jurassic-Cretaceous of the northwestern Brooks Range which contain no schist fragments to only traces of schist, even though they contain an abundance of other rock fragments. Although the schist content is low, it is one of the most abundant rock types in this suite.

-quartzite occurs only as a trace in four upper and lower Cretaceous samples (RRR-435, 440, 431, and 42I):

Sedimentary rocks - although containing a low abundance relative to total mineralogy (trace to $7.0 \%$ ), one of the most abundant rock fragment types in most samples along with chert or schist is mudstone (argillite and/or slate).

siltstone content is low in general; it occurs in abundance only in $\mathrm{RRR}-431$ (2.4\%).

carbonaceous organic matter occurs in abundance (11.1\%) as parallel aligned stringers and fibers only in RRR-416. Some plant cellular structures seen. 


\section{PROVENANCE:}

Major sources:

1. Sandstone predominantly derived from low-grade metamorphic quartz muscovite and biotite schist terrain, that also included some metamorphic quartzite; this terrain could also be the source for the abundant strained quartz, muscovite and biotite, traces of apatite, and epidote.

2. A fine-grained sedimentary rock source - mainly mudstone or argillite or slate, minor siltstone. Some mudstone clasts may be ripped-up clasts of penecontemporaneous mud bottom scoured by currents.

3. Chert derived from erosion of chert nodules in limestone beds or sedimentary bedded cherts (e.g. deep-water radiolarian cherts) or devitrified acidic volcanic glass.

Minor source:

Intermediate volcanic (andesite?) source for pilotaxitic textured volcanic rock fragments, plagioclase feldspar, and magnetite/ilmenite. Basaltic(?) source for the lava fragments with intersertal texture. Source for euhedral normal or unstrained quartz and embayed quartz.

Major source for RRR-426 tuff $=$ ash falls produced abundant glass shards from explosive acidic (rhyodacitic or dacitic in composition) eruption; also source for embayed volcanic quartz; abundant volcanic quartz and euhedral plagioclase feldspar in this sample.

Acid plutonic or intrusive source (e.g. granite, granodiorite, or diorite); possible source for micrographic intergrown feldspar and quartz in RRR-LIL, microcline in RRR-418, and large biotite flakes in many sections; also source for quartz, untwinned feldspars (orthoclase), plagioclase feldspar, zircon, and green toumaline. However, no large plutonic rock fragments observed in this suite. This may reflect the fine grain sizes of the samples (plutonic rock fragments do not exist at that size).

Polycrystalline or mosaic quartz = vein quartz source, probably associated with chert source as micro quartz veins occur in the chert clasts. Some mosaic quartz may have a quartzite origin.

Most quartz and other mineral clasts on the whole are too angular to be recycled from quartz-rich sedimentary rocks. 


\section{COMPOSITIONAL MATURITY:}

\section{Relief and Climate:}

In general, low gentle to moderate relief (e.g. low hilis, low stream gradients) resulted in extensive chemical destruction of most unstable mineral and rock fragments to clay, thus enriching the abundance of quartz and chert and producing clay matrix and fine grain size. The climate was mainly warm and humid temperate where chemical weathering prevailed over mechanical weathering causing most unstable mineral and rock fragments to decompose. Some periods such as winters where mechanical weathering prevailed over chemical weathering produced some unstable rock fragments which were removed by erosion due to sone moderate topography.

Like the upper Cretaceous rocks of the Waring basin, these upper and lower Cretaceous rocks are compositionally mature to supermature (enriched in quartz and chert, low in rock fragments and unstable minerals) whereas the lower Cretaceous rocks of the Waring basin are compositionally immature (with abundant unstable detritus). 
GENERAL:

In summary, the types and relative abundance of minerals as well as textures in the upper Cretaceous samples and lower Cretaceous samples (RRR-435 and 440) from the Sagwon area are very similar. No major differences were observed, suggesting that from early through late Cretaceous time this basin received sorted detritus from a predominantly low-grade metamorphic (schist and quartzite) and fine-grained sedimentary (mudstone, chert and vein quartz) provenance. There were some active acidic volcanic eruptions near this basin during upper Cretaceous as evidenced by rhyodacitic vitric tuff sample RRR-426. Some volcanic lava flow terrain (of intermediate composition e.g. andesites? and basalts?) also contributed minor detritus as well as some possible acid plutonic provenance (granodiorite? quartz diorite?). The abundant carbonaceous plant matter in RRR-416 suggests the provenance contained some abundant plant life. The abundance and types of minerals of this upper and lower Cretaceous suite is similar to that of the upper Cretaceous of the Waring basin (similar provenance in Brooks Range being eroded). They are similar in that both suites contain very high quartz and chert content, relatively abundant muscovite and some biotite, abundant schist, and mudstone fragments; low amounts of volcanics, little or no pyroxene, hornblende or plutonic rock fragments.

However, this suite differs significantly from the lower Cretaceous of the Waring basin and the Jurassic-Cretaceous of northwestern Brooks Range in mineralogy in that the lower Cretaceous of the Waring basin are quartz poor (the Jurassic-Cretaceous sandstones are not quartz poor), contain abundant volcanic rock fragments (of several textural types), altered amygduloidal volcanic glass, a variety of mudstone clasts (no radiolarian types seen in this upper Cretaceous suite), abundant pyroxene or hornblende, plagioclase feldspar (andesine), some acidic plutonic rock fragments, and contain almost no schist, muscovite, or biotite fragments. Thus, the upper and lower Cretaceous of the Sagwon area and the upper Cretaceous of the Waring Mountains significantly differ in mineralogy from the lower Cretaceous of the Waring basin and Jurassic-Cretaceous of northwestern Brooks Range (Delong Mountains). This distinctive mineralogy of the Sagwon sandstones can be used to differentiate these major Cretaceous suites in thin section (e.g. as collected in cores). The upper and lower Cretaceous suite of the Sagwon area are also finer grained in general than all the other suites, a further aid to its recognition. 
The textural maturity and fine grain sizes of the upper and lower Cretaceous arenites suggest deposition in a moderate energy enviroment such as offshore littoral bar sands (strandline) or deltaic sands (overbank, bay mouth bar, distributary channel sands). The general angularity of the framework clasts and the occurrence of mica and soft schist and mudstone clasts suggest deposition was not in a high energy and abrasional surf or eolian environment. The micas would probably settle out only in a lower energy environment with the quartz and the abundant "soft" mudstone (ripped-up) clasts and schist clasts (in these sandstones) would have been completely destroyed by extensive reworking by abrasional processes in a surf environment.

The fine grain size, good to fair sorting, and orientation of muscovite and schist fragments and laminations in some arenites suggest transport by weak currents (low flow regime?) in which the fines (clays) were winnowed out and coarser material left behind. The high abundance of quartz in the samples suggests some abrasion and destruction of the unstable "softer" mineral and rock clasts and thus enrichment of sediment in quartz and chert in strandline deposits. There are only low percentages of rock fragments in the samples. The high abundance of quartz may also reflect abundant quartz-rich rocks in the source area and/or more probably, the very fineto fine-grained sand size of the samples in which, in general, there is also a dearth of rock fragments (these were completely destroyed to clays before breakdown to this fine size).

The upper Cretaceous wacke samples of the Sagwon area are even more texturally immature than the arenites. The abundance of matrix (original matrix probably only in RRR-412, 424, and 416), fair sorting, and angularity of the framework clasts suggest that the wackes were deposited in an even lower energy environment than the arenites with almost no winnowing of fines, no reworking, and rapid burial, as in deep-water marine enviromment (such as turbidites or deltaic overbank, protected bays, low energy tidal flats, lagoonal, or swamp enviroments). RRR-LI6 contains a concentration of carbonaceous plant matter in laminae suggesting rapid burial after deposition in the above environments which protected the plant matter from oxidation and decay. The other wackes (RRR-413, 416, 418, and 431) appear to have diagenetically formed celadonite matrix (ghosts of grain boundaries of rock fragments of same composition as matrix). Although some matrix may be original in part, it is difficult to tell how much is original or has been diagenetically produced after deposition in these fine-grained wackes. If these wackes contain dominantly diagenetically formed matrix, then they probably were deposited in a moderate energy environment where most of the original clays were winnowed similar to that of the arenites. Upper Cretaceous vitric tuff or tuffaceous sandstone sample RRR-426 contains abundant glass shards floating in a clay matrix (52\%) of mixed terrestrial detritus (silt sized mica and clay rip-ups), suggesting an origin from ash falls of glass shards settling into a low energy marine environment in which gentle current dispersal resulted in admixing with terrestrial clays, silt sized mica, and clay rip-ups (e.g. as in deep ocean slow settling shards settle with terrestrial clays or in a lake, or in a protected bay, lagoonal or shallow marine below wave base). 


\section{DIAGENETIC HISTORY:}

1. Some compaction of carbonaceous plant fragments, schist, and muscovite to produce the contorted and crushed appearance of these clasts. Some quartz overgrowths precipitated from silica-rich water in RRR-413 and 431.

2. Rock fragments (volcanic, sometimes schist) altered to micaceous clay and celadonite and to opaque iron oxides, commonly forming indistinct grain and matrix boundaries.

3. Carbonate and/or sericite replacement of plagioclase feldspar.

4. Replacement by matrix and carbonate of quartz, mosaic quartz, and feldspar producing serrated or irregular grain boundaries on these mineral clasts.

5. Carbonate cement, rare rhombs of dolomite, and some limonite/ leucoxene or henatite formed by oxidation of iron minerals (e.g. biotite) and by precipitation in pores by ground water.

6. Extensive pressure solution compaction in RRR 435, interpenetration of adjacent quartz and chert grains suggests deep burial. In vitric tuff sample RRR-426 pressure solution as a result of compaction produced stylolites (as in limestones). The shards have partially devitrified or altered to the zeolites, heulandite and analcime (analcite) probably in an alkalic environment as well as quartz, and chalcedony. Because of high quartz content and 1 w percentage of compositionally unstable mineral and rock fragments (particularly volcanic), the diagenetic alteration is not as severe as in the lower Cretaceous rocks of the Waring basin or the Jurassic-Cretaceous rocks of northwestern Brooks Range; it is more like the upper Cretaceous of the Waring basin. Many of these samples contain carbonate cement. 
PETROGRAPHTC REPORT

UNION OIL COMPANY

North Slope Samples

Sample No. RRR-LI2 KuparuK Antidite Analyst: A. R. Niem

Rock Name: fine-grained quartzose-feldspathic wacke

Number of points counted: $1250 \quad$ Date: June 23, 1972

Slide Quality: good

TEXTURE

Framework:

Porosity: 14.5\%; Type: intergrain; between framework clasts and part of. pores filled with clay matrix

Median grain size: very fine sand; Range: coarse silt to very fine sand

Sorting: well-sorted

Shape and rounding: quartz = angular, elongate to equidimensional feldspar = elongate, prismatic

Textural Maturity (Folk): Immature to mature: abundant matrix angular grains sorting good

Preferred orientation: none

\section{MINERALOGY}

Framework minerals:

Quartz: 29.1\%; Types: angular quartz with strained and straight or normal extinction (28.7\%); minor mosaic or polycrystalline quartz $(0.4 \%)$

Feldspar: 4.8\%; Types: plagioclase feldspar (albite to oligoclase composition); few untwinned feldspar (orthoclase?)

Micas: 1.0\%; Types: muscovite flakes and shreds; trace of biotite Amphibole: trace; hormblende - pleochroic green, good cleavage Heavy minerals: 2.0\%; hematite; trace of zircon

Rock fragments:

Volcanic: trace; pilotaxitic texture (aligned microlites of plagioclase feldspar).

Mudstone: $3.4 \%$; very large angular dark iron-stained clay clasts containing a few silt-sized quartz and mica flakes

Compositional Maturity (Folk): mature to supermature: very high quartz content; but also contains unstable feldspar

Diagenetic alteration: oxidation and precipitation of hematite cement 
Matrix: ( $5.03 \mathrm{~mm}$ ) 22.7\% original clay matrix (no ghosts or altered minerals seen and framework grain boundaries distinct)

Types: clay composed of tiny aggregates of colorless to iron-stained clay minerals with birefringence (optical characteristics like chalcedony and chert)

Cement: $22.3 \%$ no cement as quartz overgrowths

Types: mainly carbonate occurring as irregular shaped pore fillings between grains; minor hematite cement and recrystallized clay minerals may also act as cement.

\section{SUMMARY}

INFERENCES AND CONCLUSTONS

Provenance:

Rock types: quartz and mica bearing provenance

1. Mica $=$ plutonic or metamorphic or reworked sedimentary deposits but lack rounding

2. Mudstone $=$ large current ripped-up clasts of local mud layer, intraformational or less likely erosion of sedimentary mudstone (cormonly too "soft" to be recycled unless the source is nearby)

3. Volcanic clasts with pilotaxitic texture = volcanic source, internediate in composition; may also be source of plagioclase

Relief and Climate: low stream gradients, gentle plains, low hills resulted in slow removal of detritus, allowed time for extensive chemical destruction of rock fragments and unstable minerals. Chemical weathering prevailed over mechanical weathering (as in warm, humid climate or even tropical?); formation of clays from unstable minerals and rock fragments; only resistant quartz of fine grain size and less resistant mica remain

\section{Depositional Environment and Transport Mechanism:}

Low energy transport and rapid deposition is suggested by fine grain size, mica flakes and that mud accumulated with fine-grained quartz. The angular grains and abundant clay matrix also suggest little reworking, abrasion or winnowing; such an environment as overbank of a deltaic enviroment, low energy tidal flat, floodplain, or deep-water environment (e.g. turbidite), lagoonal, shallow marine, protected bays, littoral bar sands. The occurrence of three large mudstone ripped-up clasts suggests higher energy currents at times scoured and ripped-up cohesje clay clasts from underlying muds.

\section{Diagenetic History: (order of history not determined)}

Cementation by carbonate. Carbonate-rich water infiltrated through pores between clay and quartz and precipitated carbonate (probably calcite) in localized zones. Solution or partial replacement of quartz grains by carbonate.

Oxidation and remobilization of hematite (minor cement).

Recrystallization of clay minerals.

Some compaction.

Good porosity for reservoir rock. 
PETROGRAPHIC REPORT

UNION OIL COMPANY

North Slope Samples

Sample No. RRR- 413

Analyst: A. R. Niem

Rock Name: very fine-grained cherty feldspathic arenite

Number of points counted: $618 \quad$ Date: June 23, 1972

Slide Quality: good to excellent; some plucking may have increased porosity

TEXTURE

Framework:

Porosity: 15.8\%; Type: predominantly intergrain; some may be due to plucking of dolomite rhombs

Median grain size: fine sand; Range: very fine sand to one medium sand sized grain

Sorting: $\operatorname{good}$

Shape and rounding: angular, irregular to elongate shaped quartz and feldspars

Textural Maturity (Folk): mature: 1. Clays winnowed out

2. Sorting good

3. but angular clasts

Preferred orientation: laminations parallel to long direction of slide

\section{MINERA LOGY}

Framework minerals:

Quartz: $35.5 \%$; Types: polycrystalline or mosaic quartz (7.2\%); strained and straight or normal extinction types (28.3\%); some interpenetration of adjacent grain boundaries of quartz; some quartz grains with tourmaline needles as inclusions

Feldspax: 7.1\%; Types: plagioclase (5.8\%); rare micro-perthite; k-feldspar (1.3\%)

Micas: 2.4\%; Type: muscovite occurs as shreds and contorted flakes

Amphibole: trace pleochroic green grain with.well-developed cleavage (possibly hornblende)

Heavy minerals: $4.3 \%$; hematite/leucoxene, tourmaline, zircon

Rock fragments:

Chert: $7.7 \%$; cryptocrystalline quartz commonly iron-stained; some radial fibrous chalcedony grains

Volcanic: $0.6 \%$; pilotaxitic texture. (aligned microlites of feldspar in iron oxide or celadonite groundmass)

Schist: $3.8 \%$; elongate clasts of mica and quartz in parallel orientation (foliation)

Mudstone: $0.4 \%$; dark opaque clay fragments containing few angular silt sized quartz grains 
Cornpositional Maturity (Folk): mature to supermature: mostly chert and quartz with some rock fragments and unstable feldspar

Diagenetic alteration:

1. Quartz and feldspar overgrowths on quartz and feldspars; some interpenetration of adjacent quartz grains due to compaction.

2. Carbonate rhombs precipitated in pores. Some replacenent of quartz grain boundaries by matrix and alteration of feldspar to sericite. Some oxidation of hematite. (Very finely comminuted fragments of hematite and clay outline boundaries between grains and also outline dolomite rhombs suggesting a formation later than dolomite.)

3. Carbonate replacement of some quartz and feldspar grains.

Matrix: (<.03 mm) 9.9\%; in part diagenetically formed matrix (some ghosts of schist and mudstone grains)

Types: clay stained by dark red hematite/leucoxene; matrix may be formed by the breakdown of mica and rolcanic fragments (some grains have indistinct boundaries which merge with matrix).

Cement: 11.8\%; Iess than $1 \%$ as overgrowths (irregularly fringing some quartz grains)

Type: mostly carbonate rhombs (dolomite) as partial pore fillings attached between two framework grains, some replaces quartz. Cementation is not as extensive as in RRR-LI2.

SUMMARY

INFERENCES AND CONCLUSTONS

Provenance:

Rock types: 1. Mica = derived from acidic plutonic or more likely metamorphic terrain.

2. Schist $=$ low-grade metamorphics

3. Mudstone $=$ erosion of fine-grained sedimentary rocks or contemporaneous current rip-ups of mud bottom.

4. Volcanic clasts with pilotaxitic texture = intermediate volcanic flow

5. Spheritic chert $=$ possibly devitrified volcanic glass or from sedimentary chert beds

Relief and Climate: gentle to moderate relief and low stream gradients resulted in slow removal and transport of unstable detrjtus allowing extensive chemical weathering; some rock fragments remain but there is a concentration of quartz and chert. Chemical over mechanical weathering as in warm temperate climate; most rock fragments broken down to silt or fine sand size or destroyed resulting in the high concentration of quartz and chert; this high concentration could also be produced by current abrasion. 
Depositional Environment and Transport Mechanism:

Fine grajn size suggests low energy current transport and deposition in low energy environments such as lagoonal, overbank, offshore littoral. (bar sands) or deeper water (i.e. below wave base) with little reworking to allow mica to settle and produce angular sediment; some weak current activity winnowed out the fine-grained material and sorted the material. Angular grains suggest little abrasion or reworking. Some fluctuation in current energy to produce laminations.

\section{Diagenetic History:}

1. Some compaction

2. Carbonate solution in groundwater and precipitation of chombs of dolomite, only partially filling pores (preferrential permeability produced by precipitated laminations of dolomite rhombs)

3. Precipitation of hematite-clay further cemented framework grains and coated dolomite rhombs

4. Rare quartz overgrowths

Porosity is high (if not artificial) = good potential reservoir like RRR- 4 I 


\section{PETROGRA PHTC REPORT \\ UNTON OIL COMPANY \\ North Slope Samples}

Sample No. RRR-4I4

Analyst: A. R. Niem

Rock Name: fine-grained cherty lithic arenite

Number of points counted: 614 Date: June 24, 1972

Slide Quality: good, except irregular slab left after grinding

\section{TEXTURE}

Framework:

Porosity: 9.7\%; Type: predominantly intraparticle; some artificial due to plucking and grinding of grains; some porosity due to diagenetic solution

Median grain size: fine sand; Range: very fine sand to medium sand

Sorting: well-sorted

Shape and rounding: angular, prismatic and sliver-shaped grains, some grains are euhedral; others are spherical

Textural Maturity (Folk): mature: 1. Clays winnowed out

2. Sorting good

3. But very angular grains

Preferred orientation: none; grains in grain support

\section{MINERALOGY}

Framework minerals:

Quartz: 32.0\%; Types: mosaic quartz (7.3\%); polycrystalline normal quartz contain microstylolitic boundaries; clear quartz with normal extinction most common (24.7\%); few strained varieties; most adjacent quartz grains have straight edge contacts; little grain interpenetration suggesting little compaction; trace of micrographic

intergrowth of quartz and orthoclase(?) feldspar Types: plagioclase (twinned) (6.0\%); k-feldspar (1.9\%); one plagioclase crystal contains plagioclase twinning with kink fold.

Micas: $0.4 \%$; Types: muscovite flakes; trace of biotite

Heavy minerals: 2.6\%; trace of zircon, green tourmaline; mostly hematite/Ieucoxene 


\section{Rock fragments:}

Chert: 11.5\%; cryptocrystalline quartz

Volcanic: $3.2 \%$ most clasts with pilotaxitic texture (parallel alignment of microlites of feldspar); some with intersertal texture

Schist: 2.9\%; elongate clasts consist of parallel aligned muscovite and silt-sized quartz

Siltstone: 8.9\%; fragments consist of abundant silt size muscovite and quartz in opaque clay matrix

Mudstone or argillite: one grain

Compositional Maturity (Folk): mature: high abundance of quartz but large amount of schist, sedimentary mudstone fragments, and volcanic fragments as well as much plagioclase feldspar and mica

Diagenetic alteration: I. plagioclase feldspar altered to patches of sericite

Matrix: (<.03 mm) 2.9\%; clay matrix may be diagenetic in origin in part by alteration of unstable schist and mudstone fragments (fragments have indistinct grain boundaries - alteration products merge with clay matrix).

Type: clays mixed with henatite

Cement: 17.4\%; no cement as quartz overgrowths

Types: carbonate $=$ dominant cement type occurs between framework grains; some hematite cement with clay occurs as black opaque aggregates between framework grains.

SUMMARY

INFERENCES AND CONCLUSIONS

\section{Provenance:}

Rock types: 1. schist $=$ metamorphic

2. Chert $=$ sedimentary chert beds or chert nodules in limestone; some contain chert replaced glass shards and whole glass bubble shards; these clasts were derived from alteration of volcanic glass.

3. Mosaic quartz - some chert with mosaic quartz suggests vein quartz as source for some of the mosaic quartz

4. Micrographic intergrowth of quartz and orthoclase = granitic source

5. Distorted kink band in feldspar suggests cataclastic deformation and stress in former environment

6. Euhedral shape of some clear unstrained quartz and feldspar suggests a volcanic source

7. Argillite, mudstone, and siltstone = sedimentary rip-up or erosion of sedimentary rocks (very low-grade metamorphism)

8. Pilotaxitic arrangement of feldspar laths = volcanic flow probably intermediate composition 
Sample No. RRR-4I4 continued...

Relief and Climate: moderate relief; some unstable fragments preserved by rapid erosion; mechanical weathering important; retention of some unstable rock fragments (not chemically destroyed) although many destroyed by chernical weathering to produce quartz and chert enriched sediment.

Depositional Environment and Transport Mechanism:

1. Winnowing of fine clay (matrix); sorting of grains during transport

2. Very angular grains suggest no prolonged abrasion such as on beach or surf; also "softer" sedimentary and metamorphic (schist) fragments abundant, would be destroyed in wave abrasion environment.

3. More likely, deltaic sand bar, bay mouth bar, shallow marine

(e.g. offshore bars) but not likely from beach or dune environments

\section{Diagenetic History:}

1. Alteration of some plagioclase to sericite.

2. Destruction of grain boundaries of schist and mudstone fragments

3. Carbonate cement precipitated in pores by ground water thereby cementing sediment into sedimentary rock

4. Some solution of quartz, mosaic quartz, and solution of grain boundaries of plagioclase feldspar grains

5. Oxidation of iron minerals to form leucoxene; remobilization of hematite to act as a cement as globular aggregates and coatings (associated with carbonate cement).

6. Although porosity has been reduced by cementation and alteration of grains, it is still high (9.7\%); this sandstone would have a good reservoir potential. 
PETROGRA PHIC REPORT

UNION OTI COMPANY

North Slope Samples

Sample No. RRR-416

Analyst: A. R. Niem

Rock Name: very fine-grained carbonaceous quartz wacke

Number of points counted: 600

Date: June 26, 1972

Slide Quality: good, no plucking

TEXTURE

Framework:

Porosity: 3.1\%; Type: intergranular

Median grain size: very fine sand; Range: coarse silt to fine sand

Sorting: fair (excluding matrix)

Shape and rounding: angular elongate quartz; also spherical and equidimensional.

Textural Maturity (Folk): immature: 1. Abundant matrix

2. Sorting fair

3. Very angular framework grains

Preferred orientation: concentrations of parallel aligned carbonaceous organic matter to form laminations.

\section{MINERALOGY}

Framework minerals:

Quartz: 22.6\%; Types: predominantly clear angular quartz with straight or normal extinction (18.8\%); minor quartz with strained or undulatory extinction; some mosaic or composite quartz $(3.8 \%)$ interpenetrated

Feldspar: 0.8\%; Type: mostly plagioclase; some untwinned feldspar (orthoclase?)

Micas: 2.8\%; Type: muscovite flakes

Trace of colorless amphibole or pyroxene

Heavy minerals: $3.3 \%$; hematite

\section{Rock fragments:}

Chert: $1.6 \%$ cryptocrystalline quartz

Volcanic: $0.3 \%$ clasts with pilotaxitic texture

Schist: 2.5\%; elongate micaceous fragments

Organic fragments: 11.1\%; abundant carbonaceous (plant) fragments parallel to bedding

Sedimentary rock fragment: $0.8 \%$; mudstone

Compositional Maturity (Folk): Supermature: almost entirely quartz and chert fragments 
- Diagenetic alteration: extensive carbonate alteration and replacement of matrix; quartz and chert grains altered to carbonate

\section{Matrix: (5.03 mm) 29.4\%;}

Probably diagenetically formed suggested by occurrence of rare ghosts of mudstone, schist, and volcanic fragments of same composition as matrix; also by grains floating in clay matrix; not in grain support; some matrix may be original; difficult to tell for sure.

Cement: $20.8 \%$; no cement as quartz overgrowths

Types: carbonate cement infiliss pores and also extensively replaces matrix and framework grains. Some carbonate pore fillings look like devitrified shards; minor limonite/leucoxene pore cement

\section{SUMMARY}

INFERENCES AND CONCLUSTONS

Provenance:

Rock types:

1. Minor source, volcanic = intermediate and basaltic flow fragments

2. Main source, low-grade metamorphic = schist; also source for muscovite and quartz

3. Mudstone $=$ sedimentary

Relief and Climate: moderate to low relief so that unstable mineral and rock fragments were not rapidly removed by erosion but were subjected to extensive chemical weathering transforming them to clay and relatively enriching quartiz and chert content in detritus; warm humid temperate climate: most rock fragments broken down by chemical decomposition thus producing quartz rich sedinent and fine grain sizes.

Depositional Environment and Transport Mechanism:

Texturally immature (fine grain size, poor sorting, abundant matrix (may be diagenetically formed), angular grains) suggest rapid current deposition in low energy environment. Currents concentrated carbonaceous plant fragments in laminae. Little or no reworking, abrasion, or winnowing (such environments as delta overbank, lagoonal, tidal flats, swamp (lots of organics preserved), offshore littoral sand below wave base, or deepwater turbidites (fine-grained upper part)). If matrix is in large part diagenetic (hard to tell for sure), the above is still true, except some winnowing of fines; the fine grain size still indicates deposition in low energy environment. (Fjeld relationships may help). The abundance of carbonaceous plant material suggests depositon in a reducing environment.

Diagenetic History:

1. Decay of plant fragments to carbon and compaction resulted in contortion of fragments.

2. Alteration of schist, mudstone, and fine-grained volcanic clasts to clay matrix. Destruction of grain boundaries.

3. Carbonate cement and minor limonite/leucoxene (oxidation) precipitated in pores by ground water. Some carbonate replacement of quartz boundaries.

Low to moderate porosity and high clay content and carbonate cement suggest this rock would have low reservoir potential. 


\section{PETROGRA PHIC REPORT \\ UNION OTL COMPANY \\ North Slope Samples}

Sample No. RRR-418

Analyst: A. R. Niem

Rock Name: fine-grained biotite bearing feldspathic wacke

Number of points counted: $70^{\prime} 7$

Date: June 26, 1972

Slide Quality: good

TEXTURE

Framework:

Porosity: 3.1\%; Type: intergrain

Median grain size: fine sand; Range: very fine to fine sand

Sorting: poorly sorted (if include the matrix); framework clasts are well-sorted

Shape and rounding: subangular to subrounded; elongate grains, some equidimensional

Textural Maturity (Folk): immature: abundant matrix poor sorting angular grains

Preferred orientation: clasts oriented perpendicular to long direction of section

\section{MINERAIOGY}

Framework minerals:

Quartz: 4].7\%; Types: angular lathlike slivers to equidimensional in shape; mostly normal or straight extinction types; minor quartz with strained or undulatory extinction; most quartz boundaries embayed by matrix or by carbonate crystals ( $36.1 \%$ )

polycrystalline or composite quartz (5.6\%) consists of clasts with interlocking strained crystalline quartz with microstylolitic or serrated boundaries

Feldspar: 6.0\%; Types: trace microcline (0.4\%), untwinned feldspar (orthoclase); angular plagioclase laths with albite twinning $(5.6 \%)$

Micas: $3.1 \%$; Types: biotite (1.3\%); muscovite ( $1.7 \%$ )

Heavy minerals: trace of ilmenite, apatite, green tourmaline, and colorless pyroxene or amphibole with good cleavage 


\section{Rock fragments:}

Chert: 1.3\%; cryptocrystalline quartz; some radiating fibrous chalcedony varieties

Volcanic: $0.4 \%$ volcanic rock fragment with pilotaxitic texture

Schist: 2.1\%; elongate clast with muscovite flakes and silt-sized quartz in subparallel alignment

Mudstone: 7.0\%; opaque very fine-grained clast

Organic fragments: trace carbonized plant fragment(?)

Compositional Maturity (Folk): mature to supermature: abundant quartz; some chemically unstable feldspar

Diagenetic alteration: aggregates of greenish celadonite around framework grains; plagioclase altered to micaceous clays and carbonate; carbonate also partially replaces quartz and sometimes mosaic quartz

Matrix: (<.03 mm) 23.1\%; probably original as grain boundaries are distinct Types: dark clays - hematite stained; minor celadonite; microcrystalline quartz and chert

Cement: 12.3\%; Types: carbonate, mostiy replaces plagioclase but some may be pore fillings (dispersed throughout section)

2. leucoxene and minor hematite occur as irregular clots and opaque masses in between grains

3. the celadonite and clay may act as a cement as well as matrix

SUMMARY

INFERENCES AND CONCLUSTONS

Provenance:

Rock types:

1. Muscovite and biotite = acidic intrusion (e.g. granite, granodiorite), or metamorphic (e.g. biotite schist); one grain with interlocking crystals of quartz and chlorite;

2. Apatite $=$ igneous or possibly metamorphic

3. Schist $=$ low-grade metamorphics

4. Orthoclase? and microcline $=$ acidic plutonic or metamorphic

5. Fine-grajned sedimentary - mudstone

Relief and Climate: low to moderate relief; slow erosion of weathered detritus allowed unstable mineral and rock fragments to be broken down to clays (matrix) by prolonged weathering. Chemical weathering greater than mechanical weathering as in warm humid climate; most of unstable mica (biotite) and rock fragments destroyed to clays by chemical weathering and thus increased the abundance in the detritus of quartz and chert (resistant). 
Depositional Environment and Transport Mechanism:

Fine grain size, poor sorting, abundant matrix (if matrix is primary) and angularity of grains suggest rapid deposition in low energy environment with little reworking or abrasion; possible environments: overbank, lagoonal, turbidite or offshore littoral sands (e.g. bars). Grains too angular and too much matrix to be surf or eolian origin.

\section{Diagenetic History:}

1. Some rock fragments broken down to matrix of micaceous clay and celadonite.

2. Ij.ttle evidence of compaction (no grain interpenetration).

3. Carbonate replaces feldspars

4. Solution and embayment by matrix of quartz grain boundaries.

5. Oxidation/hydration of ilmenite to leucoxene and minor amounts of carbonate rhombs precipitated in pores. 
PETROGRAPHIC REPORT

UNION OIL COMPANY

North SIope Samples

Sample No. RRR-421

Analyst: A. R. Niem

Rock Name: very fine-grained schistose subfeldspathic lithic arenite

Number of points counted: 643 Date: July I, 1972

Slide Quality: poor, many fractures creating artificial porosity

\section{TEXTURE}

Framework:

Porosity: 5.2\%; Type: artificial due to fractures parallel to bedaing pulling section apart

Median grain size: very fine sand; Range: coarse silt to fine sand

Sorting: fair to moderate

Shape and rounding: angular quartz; elongate shreds of schist and mica (rectangular and contorted)

Textural Maturity (Folk): mature: 1. Little matrix

2. Fair sorting

3. Grains angular

Preferred orientation: argillite and schist fragments and elongate quartz aligned parallel to the long direction of the thin section

\section{MINERATOGY}

Framework minerals:

Quartz: 51.6\%; Types: clear elongate and angular quartz with mostly straight or normal extinction ( $48.2 \%)$; some quartz with strained or undulatory extinction some quartz grain boundaries are embayed and serrated; polycrystaliine or mosaic quartz (3.4\%)

Feldspar: 0.3\%; Type: mostly albite twinned plagioclase; trace of untwinned feldspar (orthoclase?)

Micas: 1.2\%; Types: muscovite flakes

Heavy minerals: trace of ilmenite/magnetite; small angular green tourmalines

\section{Rock fragments:}

Chert: 2.9\%; cryptocrystalline quartz; same size as quartz grains; some chert greenish color due to intergrowth of celadonite and cryptocrystalline quartz

Schist: 12.2\%; low-grade quartz mica schist fragment; elongate in shape; compacted and contorted between quartz grains 
Sample No. RRR-42I continued ...

Rock fragments: continued...

Quartzite: trace; elongate clast of polycrystalline quartz; the crystalline quartz is elongate, has strained extinction, and contains microstylolitic boundaries (serrated)

Compositional Maturity (Folk): mature: high abundance of quartz but many chemically unstable schist fragments

Diagenetic alteration: 1. Some plagioclase altered to sericite

2. Quartz grain boundaries embayed.

Matrix and Cement: 26.2\%; no cement as quartz overgrowths

Types: mainly greenish celadonite-chlorite; some leucoxene-hematite cement between framework grains and/or may be cementing some grains together, difficut to tell; also replaces some grains

SUMMARY

INFERENCES AND CONCLUSTONS

Provenance:

Rock types: 1. Iow-grade metamorphics: quartz mica schist and some metaquartzite; could be source for the abundant strained or undulatory quartz and muscovite.

2. Vein quartz or quartzite could be source for sutured mosaic or polycrystalline quartz;. grains are too angular to be recycled

3. Chert beds, limestone nodules (sedimentary) or devitrified volcanic silicic glass $=$ source for chert clasts

Relief and Climate: moderate relief (hills) - relatively rapid erosion of metamorphics before complete chemical breakdown to clay by weathering. Mechanical weathering dominated over chemical at times (temperate climate); rocks were fragmented.

Depositional Environment and Transport Mechanism:

Current deposition to align schist fragments; winnowing of clay and sorting of material, such as in a strandline environment; deposition in a low energy environment (fine grain size) with no extensive reworking or abrasion (angular grains and "soft" schist fragments). Too angular to be eolian or surf; probably offshore littoral, bar sands, deltaic bay mouth bars, or marine; might be moderate to low energy.

\section{Diagenetic History:}

1. Compaction (burial) resulted in crushed and contorted appearance of schist and muscovite flakes.

2. Oxidation of iron minerals and celadonite to leucoxene/hematite and hydration; diagenetic formation of celadonite.

3. Alteration of plagioclase to patches of sericjte.

4. Porosity is high - potential reservoir rock. 
PETROGRAPHIC REPORT

UNION OIL COMPANY

North Slope Samples
Sample No. RRR-424
Aufeis
Analyst:
A. R. Niem

Rock Name: very fine-grained quartzose-feldspathic wacke

Number of points counted: 633

Date: July 30, 1972

Slide Quality: partial coverage; one end is smoothed off

\section{TEXTURE}

Framework:

Porosity: 3.0\%; Type: intergranular

Median grain size: very fine sand; Range: coarse silt to fine sand one grain is medium sand size

Sorting: fair

Shape and rounding: angular

Textural Maturity (Folk): immature wacke: 1. Abundant matrix

2. Fair sorting

3. Angular grains

Preferred orientation: faint orientation of mica and elongate clasts perpendicular to long direction of thin section

\section{MINERALOGY}

Framework minerals:

Quartz: 38.8\%; Types: clear angular quartz (35.0\%); elongate and equidimensional in shape; many grains have edges corroded; most quartz wi.th strained extinction; some quartz with normal extinction; polycrystalline

Feldspar 5.6\% or mosaic quartz with normal extinction (3.8\%)

Feldspar: 5.6\%; Type: plagjoclase feldspar albite twinned; some untwinned varieties

Micas: $4.4 \%$; Types: muscovite $(1.7 \%)$; biotite $(2.7 \%)$; trace of chlorite flakes

Heavy minerals: 9.4\%; Types: leucoxene and hematite; magnetite/

ilmenite; zircon

Others: $7.2 \%$ carbonate occurs as scattered grains completely to partially replacing feldspar grains and as pore fillings

\section{Rock fragments:}

Chert: $0.6 \%$ cryptocrystalline quartz often stajned with iron

Volcanic: oxides, rare fibrous chalcedony varieties

Volcanic: $0.1 \%$; clasts with plagioclase laths in pilotaxitic texture

Schist: $0.7 \%$ in clay groundmass Schist: $0.7 \%$; quartz mica schist clast containing blebs of quartz
Mudstone/argillite: 
Compositional Maturity (Folk): mature: high abundance of quartz but high $\%$ of unstable feldspar, biotite, and mica

Diagenetic alteration: 1. Plagioclase feldspar replaced by carbonate

2. Oxidation of ilmenite/magnetite to leucoxene.

3. Alteration of some biotite grain boundaries to opaque iron oxide

4. Embayment of quartz edges by matrix.

Matrix: (<.03 mm) 25.9\%; original

Types: clay dispersed with opaque iron oxides occurs around grains; partial matrix support of grains; some volcanic clast boundaries are indistinct $=$ may be matrix was diagenetically formed in part (although there are too few volcanic fragments to produce this great abundance of matrix).

Cement: none as quartz overgrowths

Types: some iron oxides and carbonate may be, in part, pore filling cement

SUMMARY

INFERENCES AND CONCIUSTONS

\section{Provenance:}

Rock types: 1. quartz muscovite schist $=$ low-grade metamorphic source

2. chert $=$ sedimentary chert bed, from nodules in limestone beds, or derived from devitrified acidic rolcanic glass

3. potash feldspar (orthoclase) $=$ acidic igneous or metamorphic

4. volcanic flow with pilotaxitic texture = intermediate volcanic

5. mosaic quartz = vein quartz or metamorphic quartzite source

6. biotite $=$ biotite schist low-grade metamorphics or derived from acidic intrusives (e.g. granodiorite)

7. argillite/mudstone $=$ erosion of fine-grained sedimentary rocks (or slate?) or more likely penecontemporaneous current rip-ups of the mud bottom

Relief and Climate: rapid erosion before chemical weathering could destroy unstable lithics; low to moderate relief (e.g. hills) resulted in slow removal and intermittent transport of detritus allowing weathering to destroy most unstable minerals. Warm, humid climate resulted in extensive chemical weathering that produced clays for matrix and destroyed most unstable rock fragments thus enriching quartz content. The weathering did not destroy all the unstable lithics and unstable micas and feldspars but did reduce them in size.

Depositional Environment and Transport Mechanism:

Abundant matrix and very low degree of rounding suggest rapid deposition of clastic material in an environment where there was little reworking (e.g. below wave base, turbidity flows in deep sea or offshore marine sands, protected bays or tidal flats); not surf or eolian because grains are too angular and too much matrix. Possible weak current transport as there is some orientation of mica and Itthic fragments and sorting. Low energy environment as suggested by abundance of muscovite and biotite flakes. Weak currents (low flow regime) transported the detritus as suggested by the fine grain size of the sandstone. 


\section{Diagenetic History:}

1. Some compaction as indicated by minor contortion of mica flakes and orientation of micas but no interpenetration of adjacent quartz grains (matrix prevented this?) to suggest extreme compaction.

2. Oxidation of some biotite and some magnetite/ilmenite to hematite and leucoxene.

3. Replacement of many feldspars with carbonate crystals. 
PETROGRA PHIC REPORT

UNION OTL COMPANY

North Slope Samples

Sample No. RRR- 426

Analyst: A. R. Niem

Rock Name: Upper Cretaceous rhyodacitic vitric tuff or tuffaceous wacke

Number of points counted: 691

Date: August 3, 1972

Slide Quality: good; rock section covers most of slide; some plucking or removal of large mineral grains creating artificial porosity; one edge is thin

\section{TEXTURE}

Framework:

Porosity: 7.2\%; Type: granular; glass in shards was dissolved leaving voids; only partly infilled with quartz and zeolites, analcite (analcime) and heulandite; high porosity but not too likely to be interconnecting pores (low permeability); also a few large silt-sized elongate needle-like voids; some have partial carbonate infilling.

Median grain size: very fine-grained (fine ash)

Sorting: well-sorted

Shape and rounding: shards are sickle-.shaped; feldspars occur as prisms and laths; angular quartz occurs as equidimensional grains

Textural Maturity (Folk): immature: highly angular shards abundant matrix well-sorted framework grains

Preferred orientation: none; three stylolites cut across perpendicular to the long direction of the thin section suggesting the bedding is also perpendicular to the long direction of the thin section.

\section{MINERALOGY}

Framework minerals:

Quartz: 5.0\%; Types: clear angular quartz; equal amounts of strained and normal extinction varieties (4.3\%); some quartz grains with embayed boundaries; polycrystalline or mosaic quartz $(0.7 \%)$ (not including shards filled with mosaic quartz) is rounded and spherical in shape 
Sample No. RRR-426 continued...

MINERALOGY continued . .

Feldspar: 2.0\%; Type: plagioclase as small laths and prisms with albite twinning

Micas: trace biotite occurs as very small flakes; chlorite Heavy minerals: $3.0 \%$; Types: opaque iron oxides $(1.6 \%)$; rare silt-sized aggregates of magnetite/ilmenite; leucoxene (abundant); some hematite/limonite; hematite fills stylolites (1.4\%)

Carbonate: 1.1\%; completely replaced some clasts of unknown original composition; also occurs as scattered grains throughout section; carbonate also fills microfractures

Zeolites: heulandite -. replaces interior of shards

Rock fragments:

Shards: 29.7\%; mostly sickle-shaped; lesser amounts of bubble wall and bubble shards (fine ash size) suspended in a fine clay matrix. Some shards have devitrified to microcrystalline mosaic quartz, feldspar, and chalcedony. Many shards have short stubby isotropic crystals of the zeolite analcime (analcite). Some original glass in shards. Chalcedony or zeolite (heulandite?) fills center of shards; analcime on edges. The analcime grows inward from the shard walls in short crystals. Chert fills interior of some glass bubbles.

Mudstone or shale: trace occurrence as silt-sized rounded fragments of brown clay and dark iron oxides.

rare clasts of yellow micaceous clay and greenish minerals occur in small aggregates or clumps with aggregate polarization.

Compositional Maturity (Folk): immature: abundant chemically unstable glass shards and fieldspar

Diagenetic alteration: 1. Solution of glass in shards and partial precipitation of quartz, analcime and heulandite in resulting voids. Analcime may be a partial devitrification product. Devitrification of volcanic dust to form part of matrix clay.

2. Compaction and development (through pressure solution processes similar to that in limestones) of stylolites parallel to original stratification.

Matrix: $\quad(<.03 \mathrm{~mm}) \quad 52.0 \%$; mostly original matrix

Types: cryptocrystalline bromish clay with admixture of iron oxides and microcrystalline quartz surrounds shards and quartz grains. Some clay may be formed authigenically from the devitrification of volcanic glass dust but usually this type of devitrification produces greenish montmorillonite, chert, or greenish celadonite. 


\section{Provenance:}

Rock types: 1. glass shards = explosive violent volcanic ash eruptions, usually acidic (rhyodacitic), viscous vesiculating magma wi.th abundant gas; rapid explosions = ash fall covered landscape and fell into marine environment possibly with slight reworking by currents and admixing with clays

2. Embayed quartz grains = volcanic

3. Trace of biotite $=$ admixture of detritus derived from acidic plutonic source; some quartz and feldspar may be derived from this source.

4. Trace of fine-grained sedimentary rock; one clast of mudstone or shale = rip-up of mud bottom by gentle current = also source of brownish detrital clay matrix.

Depositional Environment and Transport Mechanism:

Ash fall of shards (into water if associated with marine strata) into a very low energy environment (such as a lake or deep ocean) probably dispersed by wind and water currents and admixed with detrital clay and iron oxides also settling at same rate with silt-sized quartz, feldspar, and biotite.

\section{Diagenetic History:}

1. Compaction and formation of stylolites by pressure solution (as in limestones).

2. Devitrification of glass shards and authigenic replacement to mostly the zeolites analcime (analcite), heulandite, and feldspar, quartz, and chalcedony. Analcime forms in alkali environment. 
PETROGRAPHIC REPORT

UNION OIJ, COMPANY

North Slope Samples

Sample No. RRR-43I Analyst: A. R. Niem

Rock Name: fine-grained quartzose-1ithic wacke

Number of points counted: $686 \quad$ Date: June 26, 1972

Slide Quality: good; except pull-apart fractures

TEXTURE

Framework:

Porosity: 9.6\%; Type: intergrain; some porosity due to thin section grinding and fractures

Median grain size: fine sand; Range: very fine to medium sand

Sorting: moderate

Shape and rounding: angular to subangular; feldspars occur as prismatic grains; quartz occurs as slivers, elongate and equidimensional clasts

Textural Maturity (Folk): immature - if matrix is original, sandstone is immature. If matrix is authigenic, sandstone is mature. Immature: 1 . sorting moderate

2. angular grains (no abrasion)

Preferred orientation: none

\section{MINERALOGY}

Framework minerals:

Quartz: 42.7\%; Types: equal amounts of normal and undulatory extinction quartz varieties; many quartz grains embayed by matrix or contain quartz overgrowths; some quartz with inclusions of gas bubbles and opaque iron oxides $(35.0 \%)$; polycrystalline or mosaic quartz (commonly iron oxide stained) consist of clasts with crystalline quartz with interpenetrating crystal boundaries (7.7\%)

Feldspar: 8.4\%; Types: mainly albite twinned plagioclase small feldspar overgrowths on many edges; less than $1 \%$ of total matrix and cement; some pericline twinning; some untwinned feldspar (orthoclase?); some fresh grains and many grains altered along twin planes; many grains altered completely to sericite and clay 
Sample No. RRR-43I continued...

MTNERAIOGY Continued ...

Micas: $0.3 \%$; Types: muscovite occurs as crushed and contorted flakes between framework grains; trace of biotite

Amphibole: trace; pleochroic green clast with well-developed cleavage (hornblende?)

Heavy minerlls: 2.0\%; Types: iron oxides (hematite) filling pores between quartz grains; and trace of zircon

Rock fragments:

Chert: $3.4 \%$; cryptocrystalline quartz; some contain micro quartz veins; a few chert clasts are composed of fibrous chalcedony.

Volcanic: 2.9\%; clasts with intersertal texture - i.e. randomily oriented microlites of plagioclase feldspar in clay groundmass

Schist: 2.9\%; elongate clasts composed of parallel aligned muscovite flakes and some quartz

Quartzite: trace; elongate clast composed of strained polycrystalline quartz and a few aligned mica flakes

Siltstone: $2.4 \%$

Mudstone: 6.7\%; very fine-grained opaque clast with randomly oriented mica flakes (fine silt size)

Compositional Maturity (Folk): submature to mature: fair abundance of rock fragments wi.th high abundance of quartz and chert

Diagenetic alteration:

1. Embayment and replacement of quartz grain boundaries by carbonate. Mosaic quartz partly replaced by iron oxides.

2. Some feldspars altered entirely to sericite (micaceous clay mineral); some altered to sericite only along twin planes.

3. Some fine-grained lithic fragments altered to greenish celadonite (looks like glauconite) and iron oxides.

4. Rare carbonate replacement of fine-grained lithic fragments.

Matrix: (<.03 mm) 11.0\%; diagenetic matrix - some ghost outlines of former lithic clasts (now matrix) seen

Types: celadonite occurs as small. aggregates around edges of framework grains.

Cement: $7.2 \%$; mostly quartz overgrowths

Types: trace of celadonite, iron oxides and carbonate cements 
Samlle No. RRR-43I continued...

SUMMARY

INEERENCES AND CONCLUSIONS

\section{Provenance:}

Rock types: I. volcanic = basaltic and intermediate lava flow source

2. schist $=$ low-grade metamorphic source

3. mudstone $=$ fine-grained sedimentary source

4. phenocrysts of amphibole in one chert clast = devitrified acjdic volcanic glass source

5. muscovite and biotite = probably metamorphic or acid plutonic (e.g. granodiorite)

6. mosaic quartz = probably vein quartz associated wi.th chert source (chert clasts have micro vein quartz)

7. chert $=$ devitrified acidic volcanic glass or recycled sedimentary chert beds or nodules from limestone beds.

8. strained quartz $=$ may be metamorphic

9. quartz with straight or normal extinction = volcanic and plutonic

Relief. and Climate: moderate relief (hills) - erosion and transport of some unstable mineral and rock detritus before complete chemical decomposition. Humid temperate climate = extensive chemical destruction of unstable detritus and resulting in high concentration of quartz and chert of fine grain size. In winter, mechanical weathering dominated over chemical weathering producing the few unstable rock fragments found in the sample.

Depositional Environment and Transport Mechanism:

Fine grain size of quartz grains and "soft" sedimentary and schist rock fragments suggest low to moderate energy depositional environment. Abundance of quartz suggests some abrasional destruction of unstable rock fragments, but this may also reflect source and the fine grain size (rock fragments do not exist). Angularity of grains reflects little abrasion or reworking. Too angular to be eolian (not beach which is high energy and lots, fabrasion, rounding, sorting, and winnowing of fines), more likely shallow marine off'shore sand deposits.

\section{Diagenetic Hi.story:}

1. Compaction crushed micas.

2. Breakdown of volcanic and mudstone rock fragments to celadonite, clays and iron oxides.

3. Oxidation of iron minerals to iron oxides such as hematite.

4. Quartz overgrowths on quartz and feldspar overgrowth on feldspar precipitation from solutions in pores = cementing agent. 


\section{PETROGRA PHIC REPORT \\ UNION OIL COMPANY \\ North Slope Samples}

Sample No. RRR- 435

Rock Name: Fine-grained quartz arenite

Number of points counted: 653

Slide Quality: good, except edges

TEXTURE

Framework:

Porosity: 11.1\%; Type: large pores, mostly granular porosity; remants of brownish glauconite grains in most of the pores that were occupied by grains

Median grain size: very fine sand; Range: very fine to fine sand

Sorting: well-sorted

Shape and rounding: quartz grains equidimensional and angular but with irregular angular interpenetration edges but not extremely sutured (compaction - pressure solution)

Textural Maturity (Folk): mature: 1. No clay matrix

2. Well--sorted grains

3. Grains angular

Preferred orientation: none; grain support

\section{MINERALOGY}

Framework minerals:

Quartz: 68.7\%; Types: both strained and unstrained extinction varieties (64.9\%); few quartz grains with rutile needle inclusions; mosaic or polycrystalline quartz with microstylolitic or sutured interlocking crystalline boundaries ( $3.8 \%$ )

Micas: $1.8 \%$; Types: muscovite $(0.9 \%)$ and biotite $(0.9 \%)$

Heavy minerals: $3.0 \%$; leucoxene (1.5\%); glauconite(?) (1.5\%); trace of epidote, ilmenite, green tourmaline, and zircon

Rock fragments:

Chert: $8.7 \%$

Schist: $2.7 \%$

Quartzite: trace 
Compositional Maturity (Folk): supermature: mainly quartz, mosaic quartz, and chert; fragments

few grains of mica or schist

Diagenetic alteration: some ilmenite grains altered to leucoxene between grains; extensive interpenetration of adjacent quartz grains by pressure-solution effects

Matrix: ( $<.03 \mathrm{~mm}$ ) 3.8\% original matrix; few rock fragments to form diagenetically and those grains have distinct boundaries

Types: micaceous yellow clay between grains; less abundant darker clay outlines some grain boundaries

Cement: trace; none as quartz overgrowths

Type: some leucoxene cement (opaque)

SUMMARY

INFERENCES AND CONCLUSIONS

Provenance:

Rock types: 1. Low-grade metamorphic source for muscovite and schist 2. Low-grade metamorphic source for quartz with strained or undulatory
extinction.

3. Vein quartz source for polycrystalline or mosaic quartz (possibly quartzite)

4. Sedimentary chert beds or devitrified acidic volcanic glass source for chert clasts.

5. Metamorphic or deuteric alteration of plutonic = epidote

Relief and Climate: low stream gradients resulted in slow removal of most unstable rock fragments and minerals; low relief allowed extensive chemical weathering. Warm humid climate; chemical weathering. exceeded mechanical weathering; destroyed most rock fragments and unstable minerals to clays; only chemically resistant quartz, chert, and mosaic quartz remain.

Depositional Enviroment and Transport Mechanism:

Current winnowed clays; abrasion destroyed softer grains; current produced good sorting; lack of matrix and high percentage of quartz suggests moderate energy (strandline) environment such as littoral (beach, offshore bar); original rounding may have been destroyed by extensive diagenetic pressure solution effects; glauconite(?) clasts suggest deposition in shallow marine environment.

Diagenetic History:

Extensive compaction as evidenced by crushed and contorted appearance of micas and schist around quartz grains and by interpenetration of quartz and chert grain boundaries. This resulted in a reduction of porosity. Observed porosity may be due to solution of unstable grains or to plucking of grains during manufacture of the thin section. 
PETROGRAPHIC REPORT

UNION OIL COMPANY

North Slope Samples

Sample No. RRR-440 Analyst: A. R. Niem

Rock Name: very fine-grained carbonate-cemented subfeldspathic lithic arenite

Number of points counted: 636 Date: July 30, 1972

Slide Quality: partial section; Canada balsam(?) lifiing up on one end

\section{TEXTURE}

Framework:

Porosity: 1.5\%; Type: intergranular and plucked grains

Median grain size: very fine sand; Range: coarse silt to fine sand

Sorting: fair

Shape and rounding: angular; elongate slivers of quartz to mostly equidimensional grains of quartz; also elongate fragments of muscovite and schist

Textural Maturity (Folk): mature: 1. Fines winnowed out

2. Fair sorting but not much rounding

Preferred orientation: none, quartz grains partly suspended in carbonate cement

\section{MINERALOGY}

Framework minerals:

Quartz: 45.5\%; Types: clear angular quartz with equal amounts of strained and normal extinction varieties (42.7\%); many quartz edges serrated and embayed by carbonate cement; some grains contain yellow tourmaline and iron oxide inclusions; polycrystalline or mosaic quartz contain strained extinction and sutured or microstylolitic boundaries (2.8\%)

Feldspar: trace; Types: plagioclase feldspar (albite twinned); untwinned feldspar (orthoclase?)

Micas: 3.1\%; Types: muscovite occurs as mostly large colorless single flakes; trace of chlorite

Heavy minerals: $6.4 \%$. Types: magnetite; ilmenite oxidized in part to hematite and leucoxene; hematite; tourmajine inclusions in quartz grains 
Rock fragments:

Chert: 1.7\%; occurs as a few well-rounded grains

Schist: $7.8 \%$; elongate clasts of quartz mica schist

Quartzite: trace; quartzite clast contains parallel aligned chlorite and muscovite flakes within crystalline quarta with strained extinction and straight interlocking boundaries.

Argillite: $0.6 \%$; occurs as clasts with aggregate polarization of tiny mica and clay fragments

Compositional Maturity (Folk): mature: high abundance of quartz and chert but also contajns much chemically unstable schist clasts and muscovite

Diagenetic alteration: minor; 1. Quartz grain boundaries embayed and replaced by carbonate

2. Ilmenite/magnetite partly oxidized on grain boundaries to hematite/leucoxene or completely altered to leucoxene

Cement: $33.0 \%$; none as quartz overgrowths

Types: mainly: carbonate cement which binds framework grains together; some hematite occurs as aggregate cement between some framework grains; much of the hematite is scattered as tiny grains in carbonate cement imparting a reddish hue to the carbonate cement.

SUMMARY

INEERENCES AND CONCLUSIONS

\section{Provenance:}

Rock types: 1. Mostly low-grade metamorphic source = abundant quartz mica schist fragments, muscovite, and chlorite; probably also source for most of the quartz particularly the strained or undulatory extinction variety and the few grains that contain tourmaline inclusions; also trace of quartzite

2. Fine-grained sedimentary or very low-grade metamorphic source for argillite/slate(?) clasts

3. Vein quartz in metamorphic terrain = sutured mosaic quartz or quartzite.

4. Chert = sedimentary or volcanic (devitrified glass)

Relief and Climate: substantial relief to allow rapid erosion of unstable schist and mica fragments before chemical weathering destroyed them to clay (e.g. moderate relief); but in general low relief allowed chemical destruction of most rock fragments and increased content of quartz and chert. Temperate climate in source area. At times (winter) mechanical weathering predominated over chemical weathering allowing breakdown of unstable schist into fragments but mainly warm humid summers, chemical weathering destroyed most rock fragments - enriched quartz content of detritus and produced fine grain. sizes. 
Sample No. RRR-440 continued...

Depositional Environment and Transport Mechanism:

Current winnowing of clay and sorting of detritus; concentration of fine grain sizes by weak current action (low flow regime); energy of depositional environment was low to allow muscovite flakes and schist fragments to settle with fine quartz grains as in bay mouth bars or overbank strata in delta deposits or shallow water strandline deposits (offshore bars). No extensive abrasional reworking suggested by angularity of quartz thus not likely high energy surf or eolian.

\section{Diagenetic History:}

1. Only minor compaction, no interpenetration of quartz grains; and mica and schist fragments are not contorted and crushed.

2. Precipitation of carbonate cement in pores, extensive reduction of porosity. This would not be a productive reservoir unless the carbonate has been redissolved. Partial embayment and replacement of quartz by growing carbonate crystals in pores.

3. At same time, oxidation in pore water of ilmenite/magnetite grains to hematite and leucoxene and redistribution of hematite oxides as the carbonate precipitated in pores. 


\section{CLASSIFICATION:}

Both RRR-239 and 252 are metamorphic rocks (probably green schist facies, low-grade metamorphism). RRR-239 is a micaceous quartzite or gneiss and RRR-252 is a highly sheared micaceous quartzite or gneiss(?).

\section{TEXTURE AND MINERALOGY:}

RRR-239 (pre-Devonian) is composed of predominantly interlocking crystals of strained or undulatory polycrystalline quartz ( $f$ ine to medium grain size; 81\%) with straight boundaries. Alignment of several trains of large contorted and bent muscovite flakes and leucoxene separated by interlocking polycrystalline quartz (14.0\%) defines a foliation. Very small chlorite needles are scattered throughout the polycrystalline quartz; some are aligned perpendicular to the general foliation. A trace of cubes and laths of hematite, colorless zircon, green tourmaline and epidote are found associated with polycrystalline quartz. RRR-252 (Devonian) is similar in mineralogy and foliation to that of RRR-239 but, in addition, RRR-252 contains a deformational fabric (it has undergone extensive shearing). RRR-252 consists of large strained coarse sand-.sized crystals (porphyroclasts) of quartz and contains a lineation or s-slip surfaces defined by subparallel muscovite crystals (rarely chlorite) set in a fine-grained granulated matrix of polycrystalline quartz (which has straight contacts and non-undulatory or normal extinction unlike RRR-239) and granoblastic micro quartz veins. The several zones of varying sizes of granulated polycrystalline quartz define shear surfaces. Several zones containing micro-"ptygmatic" folds defined by micro-granular quartz veins and magnetite are cut across by the megascopic fabric of trains of muscovite flakes.

\section{ORIGIN :}

In both RRR-252 and RRR-239 the subparaljel orientation of large muscovite flakes suggests that these samples are metamorphic quartzite not sedimentary quartzite; in addition, little pressure solution effects on the quartz as formed in sedimentary quartzites during burial) took place as the interpenetrating contacts between adjacent quartz grains are straight not sutured or microstylolitic. Directed stress forced muscovite to grow in sheets (along slip surfaces) and the quartz to be recrystallized producing a gneissic? foliation. The green schist? (quartz, muscovite, chlorite) mineralogy suggests low-grade regional metamorphism. No high-grade metamorphic minerals are present such as kyanite in this limited sample. Since these are quartz-rich metamorphics, they were most likely derived from clean quartz sandstones (quartz arenites) or chert with some clay detritus from which muscovite and chlorite formed during metamorphism. The few relict large "porphyroclasts" of strained quartz in RRR-252 are probably relict quartz grains from the sandstone. The rest of the quartz clasts in the sandstone were apparently granulated (intensely crushed) to form the quartzose matrix during shearing. RRR-252 although similar in mineralogy and foliation to that of RRR-239, does show the effect of extreme shearing evidenced by elongate zones of various sizes of granulated quartz. 
The ptygmatic folds of micro granular quartz and magnetite in RRR-239 probably first formed by close small-scale microscopic folding of s-surfaces. Then, as deformation proceeded from a different direction, the s-surfaces were apparently rotated and sheared out. Subsequent growth of muscovite and minor chlorite crystals along the new shear surfaces produced a new megascopic foliation cutting across the older ptygmatic folds. Both of these metamorphic quartzites could have served as source terrain from which micaceous quartzite, quartzite, and mosaic quartz clasts found in abundance in the upper Cretaceous sandstones of the Waring basin (mountains).

Comment (Rosé): RRR-252 may be the same formation as Devonian sandstone samples RRR-276 and 359, Schwatka Mountains.

\section{GENERAL:}

Both RRR-276 and RRR-359 (Devonian sandstones) and metamorphic micaceous quartzite RRR-252 may appear megascopically similar in the field (wel]-indurated and quartz-rich) to have been included in the same formation. However, considering their apparently different textures, mineralogy, and origins suggested under the petrographic microscope, I am hesitant to include them in the same formation. Under the microscope, RRR-276 and 359 are obviously clastic composed of weathered and eroded angular fragments of predominantly quartz and chert and rare mudstone fragments well-cemented and outlined by carbonate or hematite/leucoxene. The distinct grains are angular and poorly sorted. Some pressure solution due to compaction (deep burial) resulted in some interpenetration of adjacent grains and produced serrated or microstylolitic boundaries, that is, a sedimentary quartzite effect, but there is no well-defined foliation or metamorphic fabric in the sandstones as there is in RRR-252 which contains aligned trains of large muscovite flakes along shear surfaces, elongate zones parallel to shear surfaces of granulated quartz, micro-"ptygmatic" folds. Also no large metamorphic flakes occur in RRR-276 and 359, nor is there carbonate or hematite cement or chert in RRR-252. Probably before low-grade regional metamorphism and extensive shearing, sample RRR-252 was a pure quartz sandstone very much like RRR-276 (though more quartz and less chert) but subsequently had been dynarnically changed.

In sumrnary, RRR-276 and 359 are quartz and chert-rich clastic sedimentary rocks that have undergone some diagenetic alteration due to deep burial but have not undergone the extensive regional low-grade greenschist metamorphism and shearing that RRR-252 has undergone and probably should not be considered from the same formation (unless this sample RRR-252 is from a shear zone in that formation). 
PETROGRAPHIC REPORT

UNTON OIL COMPANY

North Slope Samples

Sample No. RRR-252 Analyst: A. R. Niem

Rock Name: Devonian sheared metamorphic micaceous quartzite or gneiss

Number of points counted: 656 Date: August 25, 1972

Slide Quality: good, except artificial porosity cracks produced as section pulled apart in one place.

\title{
DESCRIPTION:
}

This metamorphic rock contains a deformational fabric. The mineral assemblage is of probable green schist facies (low-grade metamorphism) mostly quartz, muscovite, and some chlorite. The megascopic fabric (foliation) is dominated by sets of s.surfaces or slip surfaces (schistosity surfaces) defined by large bent muscovite and less comonly chlorite crystals in a subparallel orientation to long direction of thin section.

The sample consists of several strained and broken large crystals ("porphyroclasts") of quartz (sutured or serrated contacts with quartz groundmass) and trains (lineation) of subparallel bent and elongate muscovite and more rarely chlorite crystals set in an abundant fine-grained granulated groundmass of polycrystalline quartz (straight crystal boundaries and non-undulatory or normal extinction) and muscovite. Granoblastic micro quartz veins (quartz crystals has straight grajn boundaries, nonundulatory extinction) cut the granulated quartz groundmass.

Trains of large bent elongate muscovite and rarely chlorite flakes define shear surfaces (parallel to long direction of slide) which in several cases cut across zones containing micro "ptygmatic" folds defined by micro-granular quartz veins and magnetite (apparently formed by close smallscale microscopic folding of s-surfaces first; micro veins and magnetite). As deformation proceeded from a different direction, the s-surfaces were rotated, sheared out, and subsequent growth of muscovite and chlorite crystals along new shear surfaces produced along a new megascopic foliation cutting across old folds. Thus, the ptygmatic micro folds trend at high angles to the dominant foliation.

\section{MINERAIOGY}

\author{
Quartz: $\quad 38.4 \%$ \\ Micas: 9.1\%; types: muscovite, rare chlorite \\ Heavy minerals: $3.3 \%$; Types: mainly hematite, leucoxene, magnetite \\ trace of epidote, zircon, few tourmaline \\ inclusions in quartz \\ Granulated quartz groundmass: $47.7 \%$
}

No primary porosity (some artificial plucking of large porphyroblastic quartz - not a potential reservoir. 


\section{ORTGIN:}

Since the most common and abundant mineral in this quartzite is quartz $(86.6 \%)$, it was likely formed from the metamorphjsm of a quartz sandstone (quartz arenite?) or chert bed with some clay detritus from which muscovite and chlorite formed.

The few large "porphyroclasts" of strained quartz are possibly relict quartz grains from a sandstone; other quartz clasts in the sandstone apparently were intensely crushed during deformation to form the granulated quartzose groundmass. Unlike sample RRR-239, the low-temperature greenschist regional metamorphism was accompanied by extreme tectonic shearing. The Devonian micaceous quartzite could have served as a source material for the micaceous quartzite clasts and mosaic quartz clasts found in the upper Cretaceous samples from the Waring Mountains and Sagwon areas. 
PETROGRAPHTC REPORT

UNION OIT COMPANY

North Slope Samples.

Sample No. RRR-239 Analyst: A. R. Niem

Rock Name: metamorphic micaceous quartzite or gneiss

Number of points counted: 804 Date: July 13, 1972

Slide Quality: good

TEXTURE

Grain size: fine to medium sand.

Sorting: large range of sizes $=$ heterogeneous

Shape: euhedral, irregular

Preferred orientation: muscovite flakes aligned to long direction of slide

\section{MINERALOGY}

Quartz: 81.1\%; Types: interlocking mostly strained polycrystalline quartz with straight grain bourdaries; some large quartz crystals filled with small quartz blebs and chlorite blebs

Micas: 18.0\%; Types: muscovite occurs as elongate flakes concentrated in layers defined by principal foliation.

chlorite as oriented aggregates of needres; some aligned perpendicular to principal foliation

Heavy minerals: $0.6 \%$; Types: mainly leucoxene; minor opaque iron oxides as irregular aggregates paraliel to mica and chlorite; some cubes to laths of hematite; large zircon; epidote; green tourmaline

\section{ORIGIN:}

Parallel orientation of large muscovite flakes suggests that this is a foliation in a metamorphic quartzite not a sedimentary quartzite; little pressure solution took place; no sutured or microstylolitic contacts; direct stress forced muscovite to grow in sheets producing a foliation; no high-grade metamorphic minerals present (such as kyanite); mineralogy suggests low-grade regional metamorphism (greenschist). The original rock before metamorphism was probably a quartz arenite. Since this is pre-Devonian basement, it could be the source for the metaquartzite fragments in the quartz and schist wackes of the upper Cretaceous of the Waring basin and Sagwon region. 
SUMARY - Group IX

Sample DWA-329

\section{CLASSIFICATION:}

Hydrothermally altered hematitic mudstone(?)

Age and Field relationship (Rosé): Triassic Shublik - appears to be a very restricted environment deposit; Schwatka Mountains

TEXTURE:

Coarse sand sized metallic hematite globules and rhombs replaced by carbonate rhombs. The metallic hematite globules are well-sorted, contain round to irregular edges that penetrate the matrix and rectangular to squarish rhombic to spherical in shape. The hernatite globules occur in an abundant microcrystalline greenish clay (celadonite, chlorite, or montmorilionite) and cryptocrystalline quartz matrix (18.4\%). No preferred orientation was observed, but most globules are in grain support. Porosity is high (23.6\%) mostly as spherical cavjties and in micro-veinlets but most of which is probably due to artificial plucking in thin section preparation.

\section{MINERALOGY:}

Quartz (9.5\%), mosaic quartz $(5.6 \%)$, and zeolites as micro-veinlets cutting across hematite replaced globules and matrix; also as silt-sized spherical clasts in matrix - may have been radiolaria recrystallized(?). Some opal lined micro-veinlets.

Mica (trace) tiny silt-sized flakes of muscovite in matrix.

Few carbonate (1.5\%) (siderite?) remnants of large rhombic crystals (now mostly roids) and partly replaced by metallic hematite.

Zeolites - bladed crystals in the micro-veinlets associated with mosaic vein quartz and barite.

Heavy minerals $(46.8 \%)$ dark opaque metallic hematite globules and metallic hematite in veinlets; partly oxidized to fibrous leucoxene and limonite around edges. The opaque metallic iron oxides are not magnetite as slide is not magnetic. The metallic hematite appears to have grown into the mudstone - sharp edges project into mudstone. Trace of pale green tourmaline in matrix. Barite crystals (well-developed cleavages) infill center of mj.cro quartz veinlets. Some very large barjte crystals partly replace matrix clays. 
DEPOSIT TONAL ENVIRONMENT AND TRANSPORTING MECHANISM:

Origin is an enigma. Initially the origin was thought to be in a restricted environment such as in Jurassic bog ores (hematitic ironstones) of England where diagenetic earthy red hematite replaces carbonate (siderite) oolites in a clay cherty matrix. However, carbonate and hematite show no concentric oolitic structure but form rhombs, squarish and rectangular masses. Although the matrix appears to be a clastic clay mudstone, the occurrence of squarish rhombic metallic hematite globules, carbonate rhombs, and micro-veinlets of zeolites, quartz, and barite does not appear to be of sedimentary origin but of a probable hydrothermal origin.

Thin section study suggests the following origin:

After lithification (perhaps millions of years later), the mudstone was subjected to a hydrothermal event (near intrusion?) in which hot solutions permeated the mudstone resulting in the growth of carbonate (siderite) rhombs which were in turn partiy or completely replaced by metaliic hematite (in an acid oxidizing environment). Some of the carbonate rhombs were fractured during growth and in some cases metallic hematite was precipitated as a fracture filling material in the carbonate rhombs and along rhomb edges. The mudstone was then further fractured (tectonically?) and silica-rich solutions permeated the fractures filling them with mosaic quartz or bladed zeolite? crystals and finally barite. Some hematite was remobilized and infilled the quartz-lined veinlets. 
Sample No. DWA-329

Analyst: A. R. Niem

Rock Name: Triassic Shublik hydrothermally altered hematitic mudstone

Number of points counted: 639 Date: August 2, 1972

Slide Quality: good; possible extensive plucking of hematite globules creating much artificial porosity; some Canada balsam(?) releasing rock from glass $=$ bubbles

TEXTURE

Framework:

Porosity: 23.6\%; Types: artificial; plucking of metallic hematite globules leaving spherical cavities and plucking of quartz veinlets

Median grain size of hematite globules = coarse sand

Sorting: very good, not including the clay matrix

Shape and rounding: voids and metallic iron oxide globules = rounded to irregular edges and spherical, rectangular, squarish polygonal and rhombic forms. Edges of metallic globules penetrate into matrix.

Textural Maturity (Folk): not applicable

Preferred orientation: none

\section{MINERAIOGY}

Framework minerals:

Quartz: 9.5\%; Types: in veinlets, strained or undulatory extinction mosaic quartz, clear interlocking grains (5.6\%); mostly straight contacts; veinlets cut matrix and hematite globules; in clay matrix, as angular siltsized fragments (3.9\%); some spherical silt-sized cavities filled with mosaic quartz, may have been radiolaria(?) recrystalizized.

Micas: trace tiny silt-sized flakes of mica in matrix Heavy minerals: 46.8\%; Types: fibrous limonite (leucoxene) oxidized around edges of dark opaque metallic hematite globules and as branch veinlets and veinlets and filaments in matrixis trace of steel gray magnetite/i.lmenite grain in matrix; dark opaque metallic hematite replacing carbonate in globules ( $43.8 \%)$; the opaque iron oxide globules are not magnetite because they are not magnetic; trace of pale green tourmaline in matrix 
Sample No. DWA-329 continued...

MINERALOGY continued ...

Carbonate: 1.5\%; remnant carbonate in large rhombic crystals partly replaced by hematite (carbonate ma be siderite)

Compositional Maturity (Folk): not applicable

Vein-filling material: 1. Rhombs of carbonate are fractured and have hematite filling the fractures. Quartz veins also cut carbonate rhombs (siderite).

2. Some veinlets of quartz are iron-stained = oxidation of magnetite by groundwater and precipitation of fibrous limonite in some veinlets and also altered edges of hematite globules.

Matrix: $\quad(<.03 \mathrm{~mm}) \quad 18.4 \%$; orjginal matrix

Types: mixture of microcrystalline greenish clay (celadonite, chlorite, or montmorillonite) and cryptocrystalline quartz (chert); also contains silt-sized angular quartz and muscovite.

Summary

Inferences and Conclusions

See Summary for the sample (preceding this description). 